\title{
The EfFects of Government Spending on ReAl Exchange Rates: Evidence from Military Spending Panel Data*
}

\author{
Wataru Miyamoto \\ Bank of Canada
}

\author{
Thuy Lan Nguyen \\ Santa Clara University
}

\author{
Viacheslav Sheremirov \\ Boston Fed
}

December 2016

\begin{abstract}
Using panel data on military spending for 125 countries, we document new facts about the effects of changes in government purchases on the real exchange rate, consumption, and current accounts in both advanced and developing countries. While an increase in government purchases causes real exchange rates to appreciate and increases consumption significantly in developing countries, it causes real exchange rates to depreciate and decreases consumption in advanced countries. The current account deteriorates in both groups of countries. These findings are not consistent with standard international business-cycle models. We propose potential sources of the differences between advanced and developing countries in the responses to spending shocks.
\end{abstract}

Keywords: military spending, fiscal policy, real exchange rates, twin deficit, risk sharing JEL Classification: E3, F3, F4

*Miyamoto: wmiyamoto@bankof canada.ca. Nguyen: tlnguyen@scu.edu. Santa Clara University, Economics Department, 500 El Camino Real, Santa Clara, CA 95053. Sheremirov: viacheslav.sheremirov@bos.frb.org. Federal Reserve Bank of Boston, Research Department T-9, 600 Atlantic Ave, Boston, MA 02210. We thank Òscar Jordà for insightful discussion, as well as Mario Crucini, Reuven Glick, Yuriy Gorodnichenko, Andrew Levin, Matteo Maggiori, and seminar participants at the 2016 West Coast Workshop in International Finance (Santa Clara, CA), Vanderbilt University, the World Bank, the IMF, the Bank of Canada, and the 2016 Asia meeting of the Econometric Society for comments and suggestions. We are also grateful to Nikhil Rao and Brock Santi for excellent research assistance, and to Suzanne Lorant for superb editorial work. The views expressed herein are those of the authors and are not necessarily those of the Bank of Canada, the Federal Reserve Bank of Boston, or the Federal Reserve System. 


\section{Introduction}

How does government spending affect the current account and the real exchange rate? Conventional wisdom — as well as mainstream macroeconomic models used by policymakers—suggests that an increase in government spending puts pressure on the domestic currency to appreciate, leading to current account deterioration (and potentially a "twin deficit") and to a decrease in consumption through an international risk-sharing condition. This mechanism holds across a wide range of models, including both New Keynesian and neoclassical models. However, empirical evidence for such a mechanism has not been settled. For example, Corsetti and Müller (2006) and Kim and Roubini (2008) find that in U.S. data, the trade balance improves after a government-spending shock. In contrast, using data for Australia, Canada, the United Kingdom, and the United States, Monacelli and Perotti (2010) and Ravn, Schmitt-Grohé, and Uribe (2012) estimate that a rise in government spending causes a trade deficit, as well as real depreciation of the domestic currency and an increase in consumption. Given these contrasting empirical results in studies of a relatively small number of countries, several questions on the effects of government spending in an open economy remain: First, does government spending cause the domestic currency to appreciate in real terms and does it worsen the current account? Second, do the effects of government-spending shocks differ across countries, especially between advanced and developing countries? Third, are there any other country characteristics, such as the exchange-rate regime or the degree of openness to trade, that can affect the transmission mechanism of government-spending shocks?

This paper addresses these important questions using a large data set for 125 countries between 1989 and 2013. We provide new evidence on the effects of government spending on the real exchange rate, current account, and consumption. Importantly, we exploit the information in both advanced and developing countries to distinguish between the effects of government spending in these two groups. Our data also let us examine the differential effects of government spending depending on exchange-rate regimes and the level of trade openness. Since government spending can affect the state of the economy and vice versa, we identify government-spending shocks using exogenous variation in international military spending. This approach has been used in the closedeconomy literature (for example, Hall 2009, Barro and Redlick 2011, Ramey 2011), but remains underutilized in the open-economy literature.

We document a number of new empirical facts: First, in response to a positive governmentspending shock, the real exchange rate appreciates on impact, and the effect is significant up to a two-year horizon. After an increase in government spending of 1 percent of GDP, the real exchange rate appreciates by over 3 percent on impact and by up to 5 percent two years after the shock. The effect is most pronounced in countries with a flexible exchange-rate regime. Consistent with Monacelli and Perotti (2010), we also find that the current account deteriorates significantly in response to a positive government-spending shock. Consumption increases substantially, peaking at about 5 percent two years after the change in government spending.

Second, the effects of government spending on the real exchange rate and consumption are sig- 
nificantly different between advanced and developing countries. The real exchange rate depreciates significantly by 3 percent in advanced countries, but it appreciates by over 4 percent in developing countries. Consumption increases with government spending in developing countries, but the effect of government spending on consumption is negative and statistically insignificant in developed countries. The current account deteriorates in both groups.

To facilitate our analysis, we compile an extensive data set for both advanced and developing countries. Covering many countries in the data set naturally leads to the use of annual data. The resulting data set consists of 125 countries in the period 1989-2013, including 96 developing countries. The variables include military spending, total government spending, and several other important national-account aggregates and macroeconomic indicators. ${ }^{1}$ Importantly, we gather information on periods of war, political risks, financial crises, and commodity exporters to examine how these factors may affect our estimates. These data facilitate our extensive robustness checks. For example, we can control for war periods, as well as financial crises periods, which may affect the economy and military spending at the same time. We also take into account political risks in each country. The findings in these robustness checks are similar to our baseline results, supporting our identification approach.

Our identification of government-spending shocks comes from the assumption that military spending is exogenous to the state of the economy. We implement this identification strategy using the local projections method, as in Jordà (2005). This methodology has been widely used in the literature on the effects of government-spending shocks (for example, Auerbach and Gorodnichenko 2012, Ramey and Zubairy 2014, Miyamoto, Nguyen, and Sergeyev 2016). Total government spending is instrumented by military spending. Hence, government-spending shocks come from fluctuations in military spending that cannot be forecasted by the lags of output, government spending, and other controls.

We compare the responses to a government-spending shock in the data with those in a standard international business-cycle model. We find that the model can explain the current-account deterioration observed in the full sample and the real exchange-rate appreciation observed in developing countries. However, for developed countries, the real exchange rate appreciates in the model, whereas it depreciates in the data, an inconsistency known in the literature as the "real exchangerate puzzle." The key discrepancy between the model and the data is in the consumption-real exchange-rate relationship, dubbed the risk-sharing condition. While the model predicts a negative relationship between the two variables, it is positive in both advanced- and developing-countries samples. In other words, we document a "risk-sharing puzzle" conditional on government spending shocks. This result is in line with the unconditional risk-sharing puzzle documented in Backus and Smith (1993) and Kollmann (1995), but is in contrast to Monacelli and Perotti (2010) and Ravn, Schmitt-Grohé, and Uribe (2012), who find that there is no risk-sharing puzzle conditional on government-spending shocks in their sample of four advanced countries. We conclude that the

\footnotetext{
${ }^{1}$ A subset of these data was used by Sheremirov and Spirovska (2015) to estimate the size of government-spending multipliers.
} 
standard model with complete asset markets is not consistent with the empirical evidence.

We then discuss three extensions of the standard model that can explain the effects of government spending in advanced and developing countries: (1) incomplete asset markets, (2) complementarity of consumption and hours worked, and (3) the presence of rule-of-thumb consumers. We find that the model with incomplete asset markets, in which agents trade only a one-period noncontingent bond, can be consistent with our empirical findings for advanced countries. In particular, an incomplete-markets model with a low elasticity of substitution between home and foreign goods can generate real depreciation and a decline in consumption after a highly persistent government spending shock. To explain our findings for developing countries, the model further needs either a high degree of consumption-hours complementarity or a large fraction of rule-of-thumb consumers, or both. A high degree of consumption-hours complementarity can reflect a relatively large size of the home-production sector or a high substitutability of market and home goods, which is more prevalent in developing countries than in advanced countries. The presence, in the model, of rule-of-thumb consumers with no access to financial markets is a form of financial frictions that is stronger than incomplete markets with bond trading. This feature is motivated by the fact that financial constraints are more severe in developing countries than in advanced countries. Both extensions of the model can explain real appreciation and an increase in consumption in developing countries. Our analyses suggest that we can explain the different responses to government-spending shocks in advanced and developing countries by varying the degree of these frictions within the same model.

We contribute to the literature on the effects of fiscal policy shocks on real exchange rates and the trade balance. A number of papers, such as Kim and Roubini (2008), Monacelli and Perotti (2010), and Ravn, Schmitt-Grohé, and Uribe (2012), examine the responses of the real exchange rate, trade balance, or current account to government-spending shocks. We differ from the existing papers in several dimensions. First, these papers often identify government-spending shocks using either sign restrictions or the Blanchard and Perotti (2002) assumption that government-spending shocks cannot respond to output within the same quarter. In contrast, we exploit the exogeneity of military spending. Auerbach and Gorodnichenko (2016) also use defense spending to examine the behavior of real exchange rates, but they focus on the United States and use the variations in the daily announcements of defense spending. Second, most of these papers use data for a few OECD countries, whereas our sample, in addition, contains many developing countries. We note that there are two papers that use relatively large sets of countries: Ilzetzki, Mendoza, and Végh (2013) assemble a data set for 20 advanced and 22 developing countries, but focus on output responses. Kim (2015) studies the effects of government spending on real exchange rates, but all of the 18 countries in his sample are developed. Our paper considers a much larger set of countries, distinguishing between advanced and developing ones, and, importantly, provides external validity to the literature on the effects of spending shocks on exchange rates, using a different identification strategy. Our results for advanced countries are consistent with the previous studies that document the "puzzling" fact that real exchange rates depreciate after a government-spending shock in some advanced countries. At the same time, with a large sample of developing countries, our paper 
suggests that the "depreciation puzzle" does not extend to developing countries.

This paper is also related to the literature examining the transmission mechanism of international business-cycle models. Similar to Enders, Müller, and Scholl (2011) and Ravn, SchmittGrohé, and Uribe (2012), we find evidence that real exchange rates depreciate after a governmentspending shock in advanced countries. However, there are two important differences. First, our data set includes a large number of developing countries, providing evidence for real exchangerate appreciation, which is consistent with a standard international business-cycle model. Second, we do not find that the conditional risk-sharing condition holds for either advanced or developing countries, in contrast to Monacelli and Perotti (2010) and Ravn, Schmitt-Grohé, and Uribe (2012). Therefore, although extensions of the standard model such as the deep habits of Ravn, Schmitt-Grohé, and Uribe (2012) and the spending reversals of Corsetti, Meier, and Müller (2012) can generate depreciation of the real exchange rate in response to a government-spending shock, they are not consistent with the increase in consumption observed in the data. In other words, predictions of these extensions are not consistent with our empirical evidence for developed and developing countries.

The rest of the paper proceeds as follows. Section 2 discusses our identification strategy. We summarize our data set in Section 3. The main empirical results are presented in Section 4, along with numerous robustness checks. We compare our results with previous literature in Section 5. Section 6 shows the challenge for theoretical models to explain our empirical results, as well as proposes potential sources of the difference between the responses in advanced and developing countries. Section 7 concludes.

\section{Econometric Specification}

There are two major strategies to identify government-spending shocks. One is the Blanchard and Perotti (2002) identification strategy, which relies on the assumption that government spending does not react to changes in output within the same quarter. While this assumption can be sensible for quarterly data, it is not likely to hold for annual data. Therefore, applying this identification strategy restricts the sample size to a small number of countries with quarterly data. In our paper, we use the second identification strategy, which presumes that changes in military spending can be treated as exogenous. This strategy was used in the closed-economy literature that exploits U.S. data (Hall 2009, Barro and Redlick 2011, Ramey 2011), but it remains underutilized in the international context.

There are two compelling reasons to use military spending changes to identify exogenous government-spending shocks in international data. First, military spending data are available for many countries at an annual frequency, and there are numerous episodes of significant variation over time, which helps us to estimate the effects of government spending more precisely. Second, changes in military spending can be treated as exogenous to business cycles in many countries. Figure 1 plots military spending as a share of GDP over time for some advanced and developing countries in our 


\section{Figure 1. Military Spending As a Share of GDP in Advanced and Developing Countries}
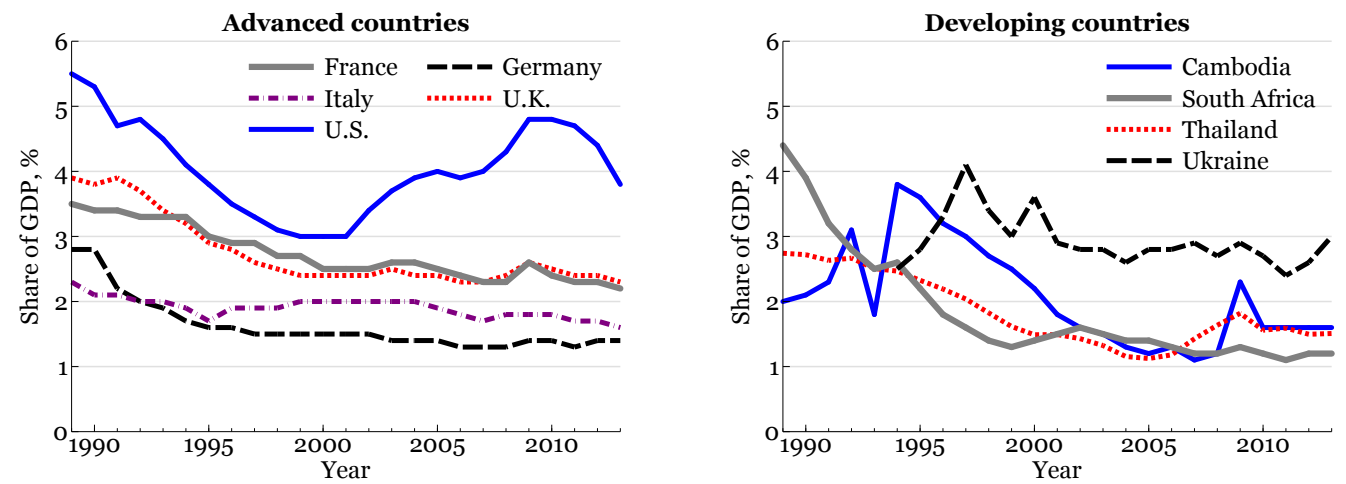

sample. In many advanced countries, such as the United States and the United Kingdom, military spending declined substantially after the collapse of the Soviet Union and the end of the Cold War. The United States increased military spending after 9/11. Other advanced countries, such as France and the United Kingdom, increased their military spending due to the allies' military operations in the Middle East, such as the Gulf War or the more recent wars in Afghanistan. In developing countries, there is more variation in military spending. Following the 2008 border disputes with Thailand, Cambodia increased its spending in 2009-2010. Recently, military spending in Ukraine has increased in response to the military struggle in the country's East and the Russian annexation of the Crimea. In 1989, South Africa started reducing military spending, following a long period of military budget expansion. This country further reduced military spending in response to the subsequent easing of tensions on the African continent. These changes in military spending are due to geopolitical events, and are considered independent from these countries' business-cycle conditions. Collier (2006), who studies the differences in military spending across developing countries, concludes that the history of domestic and international conflicts, arms races with neighboring states, and vested interests of the military, which are considered exogenous to the state of the economy, are the main determinants of such differences. ${ }^{2}$

We estimate the effects of government spending on the real exchange rate and other variables of interest using Jordà's (2005) local projections method. This method has a number of advantages over the vector autoregression (VAR) approach. First, the local projections method does not constrain the shape of the impulse response function (IRF) in the way the VAR does. Given potential heterogeneity across countries in the level of development and institutions, it is important to impose as few restrictions as possible. Second, the local projections method is flexible, as the same variables do not have to be used in each equation. Third, this method allows us to account for cross-country

\footnotetext{
${ }^{2}$ There are some cases when the exogeneity assumption may not hold. For example, wars associated with a large number of deaths and significant destruction of capital can lead simultaneously to a decline in output and an increase in government spending. Similarly, the oil exporters benefiting from an increase in oil prices can increase both output and spending. In our baseline specification, we control for the average effects of wars by including a war dummy, and in Section 4.6, we show further that controlling for these special circumstances does not change our findings.
} 
correlations of residuals using straightforward inference. In the results section, we report standard errors clustered by country.

Specifically, we estimate the following equations:

$\frac{x_{i, t+h}-x_{i, t-1}}{x_{i, t-1}}=c+\alpha_{i}+\beta_{h} \frac{\Delta g_{i t}}{y_{i, t-1}}+\Phi^{x}(L) \frac{\Delta x_{i, t-1}}{x_{i, t-2}}+\Phi^{g}(L) \frac{\Delta g_{i, t-1}}{y_{i, t-2}}+\boldsymbol{\gamma}^{\prime} \boldsymbol{z}_{i t}+\varepsilon_{i t}$, for $h=0,1,2, \ldots$,

where $x_{i t}$ is a variable of interest, such as the real exchange rate, in country $i$ and year $t, g_{i t}$ is total government spending, $y_{i t}$ is output, $\boldsymbol{z}_{i t}$ is a vector of controls, $\varepsilon_{i t}$ is the error term, $\alpha_{i}$ represents country fixed effects, and $\Phi^{x}(L)$ and $\Phi^{g}(L)$ are lag polynomials. We instrument $\Delta g_{i t} / y_{i, t-1}$ with $\Delta g_{i t}^{\mathrm{m}} / y_{i, t-1}$, where $g_{i t}^{\mathrm{m}}$ is military expenditure, to address the endogeneity of $g_{i t}$. In this specification, $\beta_{h}$ measures the $h$-period ahead response of variable $x$ to an increase in government spending of 1 percent of GDP. In the baseline specification, the vector of controls $\boldsymbol{z}_{i t}$ includes a war index and one lag of the real GDP growth rate. The war index takes a value of 1 when country $i$ has a conflict at time $t$. This war index controls for the fact that wars, on average, may have different effects on $x$. The lagged real GDP growth rate controls for the state of the economy. We note that Barro and Redlick (2011) advocate for using the unemployment rate lag to control for the state of the economy. In our case, controlling for lagged unemployment without lagged output growth, or in addition to lagged output growth, does not have a material effect on the results. To keep our specification parsimonious, we therefore omit unemployment from our baseline estimation. In the robustness section, we augment the baseline with time fixed effects $\left(\delta_{t}\right)$ and other controls such as the unemployment rate $\left(u_{i t}\right)$.

\section{Data}

Our data set includes government spending, military spending, real exchange rates, consumption, current accounts, a war index, and several other macroeconomic variables in 125 countries (29 advanced and 96 developing countries) between 1989 and 2013. To the best of our knowledge, this is the most comprehensive country coverage available to date to analyze the effects of government spending. The military expenditure data are taken from the Stockholm International Peace Research Institute (SIPRI). SIPRI collects military spending data from several sources, including government agencies and international organizations. The SIPRI military spending data include all spending on current military forces and activities such as personnel payment, procurement, operations, military research and development, and construction. The largest component of military spending is usually salaries and benefits of military personnel. The data are at an annual frequency.

We obtained the real effective exchange-rate data from the International Monetary Fund's International Financial Statistics (IFS) and Bruegel. ${ }^{3}$ An increase in the REER means an appreciation. The data on the current account as a percentage of GDP come from the World Economic Outlook (WEO)

\footnotetext{
${ }^{3}$ Bruegel, a European think-tank, provides annual CPI-based real effective exchange rates (REERs) for 172 countries during the 1992-2014 period. This is the most comprehensive REER data set available.
} 
Table 1. Descriptive Statistics

\begin{tabular}{|c|c|c|c|c|c|c|c|c|}
\hline & $\begin{array}{l}\text { Obs. } \\
\text { (1) }\end{array}$ & $\begin{array}{r}\sigma_{\frac{\Delta g}{g}} \\
(2)\end{array}$ & $\begin{array}{c}\sigma_{\frac{\Delta g^{\mathrm{m}}}{g^{\mathrm{m}}}} \\
(3)\end{array}$ & $\begin{array}{c}\sigma_{\frac{\triangle \mathrm{REER}}{\mathrm{REER}}} \\
(4)\end{array}$ & $\begin{array}{r}\sigma_{\frac{\Delta c}{c}} \\
(5)\end{array}$ & $\begin{array}{l}\sigma_{\frac{\mathrm{TB}}{y}} \\
(6)\end{array}$ & $\begin{array}{c}\sigma\left(\frac{\Delta g}{g}, \frac{\Delta g^{\mathrm{m}}}{g^{\mathrm{m}}}\right) \\
(7)\end{array}$ & $\begin{array}{l}\frac{g^{\mathrm{m}}}{g} \\
(8)\end{array}$ \\
\hline Full sample & 2,766 & $\begin{array}{c}5.3 \\
(3.1)\end{array}$ & $\begin{array}{l}12.7 \\
(5.6)\end{array}$ & $\begin{array}{c}6.4 \\
(2.8)\end{array}$ & $\begin{array}{c}5.5 \\
(4.2)\end{array}$ & $\begin{array}{c}5.8 \\
(4.4)\end{array}$ & $\begin{array}{c}0.23 \\
(0.25)\end{array}$ & $\begin{array}{c}0.16 \\
(0.14)\end{array}$ \\
\hline Advanced economies & 682 & $\begin{array}{c}2.7 \\
(2.3)\end{array}$ & $\begin{array}{c}7.7 \\
(3.9)\end{array}$ & $\begin{array}{c}4.2 \\
(1.6)\end{array}$ & $\begin{array}{c}2.7 \\
(2.1)\end{array}$ & $\begin{array}{c}3.5 \\
(3.4)\end{array}$ & $\begin{array}{c}0.24 \\
(0.21)\end{array}$ & $\begin{array}{c}0.13 \\
(0.13)\end{array}$ \\
\hline Developing countries & 2,084 & $\begin{array}{c}6.1 \\
(2.9)\end{array}$ & $\begin{array}{l}14.2 \\
(5.2)\end{array}$ & $\begin{array}{c}7.1 \\
(2.7)\end{array}$ & $\begin{array}{c}6.4 \\
(4.3)\end{array}$ & $\begin{array}{c}6.5 \\
(4.5)\end{array}$ & $\begin{array}{c}0.23 \\
(0.26)\end{array}$ & $\begin{array}{c}0.17 \\
(0.14)\end{array}$ \\
\hline Fixed exchange rate & 1,266 & $\begin{array}{c}5.1 \\
(3.3)\end{array}$ & $\begin{array}{l}12.5 \\
(6.5)\end{array}$ & $\begin{array}{c}4.5 \\
(2.2)\end{array}$ & $\begin{array}{c}4.9 \\
(4.0)\end{array}$ & $\begin{array}{c}5.9 \\
(5.1)\end{array}$ & $\begin{array}{c}0.23 \\
(0.43)\end{array}$ & $\begin{array}{c}0.17 \\
(0.16)\end{array}$ \\
\hline Flexible exchange rate & 1,500 & $\begin{array}{c}5.2 \\
(3.5)\end{array}$ & $\begin{array}{l}13.3 \\
(8.2)\end{array}$ & $\begin{array}{c}7.7 \\
(3.3)\end{array}$ & $\begin{array}{c}5.8 \\
(4.8)\end{array}$ & $\begin{array}{c}5.2 \\
(3.6)\end{array}$ & $\begin{array}{c}0.23 \\
(0.36)\end{array}$ & $\begin{array}{c}0.15 \\
(0.12)\end{array}$ \\
\hline
\end{tabular}

Notes: Column (1) shows the number of observations. Columns (2)-(6) summarize the average standard deviations $(\sigma)$ of the growth rates of government spending $(\Delta g / g)$, military spending $\left(\Delta g^{\mathrm{m}} / g^{\mathrm{m}}\right)$, real effective exchange rates $(\Delta R E E R / R E E R)$, consumption $(\Delta c / c)$, and of the trade balance-to-output ratio (TB/y). Column (7) shows the correlation of military-spending and governmentspending growth rates, $\sigma\left(\Delta g / g, \Delta g^{\mathrm{m}} / g^{\mathrm{m}}\right)$. Column (8) reports the mean share of military spending $\left(g^{\mathrm{m}}\right)$ in total spending $(g)$. The numbers in parentheses represent one standard deviation across countries.

database. The WEO reports data for 189 countries, and goes back to 1988 for most of the countries. ${ }^{4}$

The data on real GDP, total government expenditure, and private consumption come from the United Nations' National Accounts Main Aggregates Database (NAMAD). Total government spending stands for general-government final consumption expenditure. ${ }^{5}$ Private consumption includes household consumption expenditure as well as expenditures of nonprofit institutions that serve households. All variables are per capita and in 2005 constant national currency units. We note that our data set includes several other variables such as the unemployment rate, for which the data come from the World Development Indicators (WDI) data set, or the debt-to-GDP ratio, taken from the IMF's Historical Public Debt database.

Finally, our war index comes from the UCDP/PRIO Armed Conflict Dataset. Gleditsch et al. (2002) and Pettersson and Wallensteen (2015) provide more detail on how they classify wars. We note that another source of the war index, the Correlates of War (CoW) project, covers the period only up to 2007; thus, we choose to use the UCDP/PRIO data to preserve sample coverage. ${ }^{6}$ The data sources and collection are summarized in Table A1 of Appendix A.

Table 1 presents major data statistics. In total, we have 2,766 observations. We note that to obtain this final data set, we dropped several countries such as Angola, Pakistan, Rwanda, and Sri Lanka, which went through extraordinary events for several years during the sample period. We also dropped extreme observations by cutting a 1 percent tail on each side. We split the sample into two groups: advanced and developing countries. The classification is based on gross national income in 2000, as estimated by the World Bank. We use this classification for two reasons: First, the year 2000 is approximately in the middle of our sample. Second, this classification was used

\footnotetext{
${ }^{4}$ Our data set also includes the net exports-to-output ratio obtained from export and import data in the World Bank's World Development Indicators (WDI) for the entire sample period.

${ }^{5}$ Public investment data are available for a small number of countries, so we only use these data for robustness checks.

${ }^{6}$ Bazzi and Blattman (2014) compare the UCDP/PRIO data with the CoW data. Besides the difference in period coverage, the UCDP/PRIO data contain more information on smaller conflicts, in particular, those with fewer than 1,000 deaths per year.
} 
by Ilzetzki, Mendoza, and Végh (2013), making our results comparable with the literature. ${ }^{7}$ About three-fourth of the observations are of developing countries.

The data are well suited to study the effects of government spending: The share of military spending in total government spending is sizeable. Military spending makes up, on average, about 13 percent of total government spending in advanced countries and 17 percent in developing countries. In both advanced and developing countries, military spending is, on average, two to three times more volatile than government spending, which helps us to estimate precisely the effects of government spending. The volatility of military spending differs substantially across countries, as the standard deviation of the volatility is fairly large. As reported in column (7) of Table 1, there is a positive correlation of total government spending and military spending, which we utilize for the instrumental variable estimation. On average, across all countries in the sample, the correlation is 0.23 . The average correlations of total government spending and military spending across advanced and developing countries are similar to each other. Our data exhibit several other important characteristics. For example, government spending is about as volatile as consumption. Real exchange rates are more volatile than consumption in both advanced and developing countries, a fact consistent with previous literature.

\section{Empirical Results}

Since standard open-economy models make sharp predictions about the relationship of the real exchange rate with the current account and consumption, this section presents the estimated responses of these variables to government-spending shocks. We also compare the responses of these variables in advanced countries with those in developing countries.

\subsection{Instrument Relevance}

Before presenting our empirical estimates, we discuss instrument relevance by focusing on the effects of changes in military spending on total government spending. Table 2 displays the coefficients of the first-stage regression for all countries, as well as separately for advanced and developing countries. $^{8}$ The pass-through of military spending to total government spending is relatively high: on average, an increase in military spending of 1 percent of GDP increases total spending by 0.46 percent of GDP. The pass-through is larger in developing countries (0.48) than in advanced countries (0.39), although the difference between the two is not statistically significant. ${ }^{9}$ Additionally, all of the $F$-statistics calculated in the first-stage regressions are well above 10 , suggesting that the weak-instruments problem is unlikely to be a concern.

\footnotetext{
${ }^{7}$ Advanced countries are those in the high-income group, while developing countries are in the middle- and low-income groups.

${ }^{8}$ Appendix B provides more detail on the composition of countries and sample periods.

${ }^{9}$ Adding other controls such as time fixed effects does not quantitatively alter these first-stage regression estimates.
} 
Table 2. First-Stage Regressions

\begin{tabular}{lccc}
\hline \hline & \multicolumn{3}{c}{ Total Spending } \\
\cline { 2 - 4 } & All & Adv & Dev \\
\hline Military spending & $0.46^{* * *}$ & $0.39^{* * *}$ & $0.48^{* * *}$ \\
& $(0.08)$ & $(0.08)$ & $(0.10)$ \\
First-stage $F$ on excluded instrument & 30.8 & 19.1 & 23.9 \\
Obs. & 2,381 & 643 & 1,738 \\
\hline
\end{tabular}

Notes: This table reports the first stage regressions for real exchange rates. Both total government spending and military spending are changes in respective spending, normalized by lagged GDP $y_{i, t-1}$.

\section{Figure 2. Responses to Government-Spending Shocks: Full Sample}
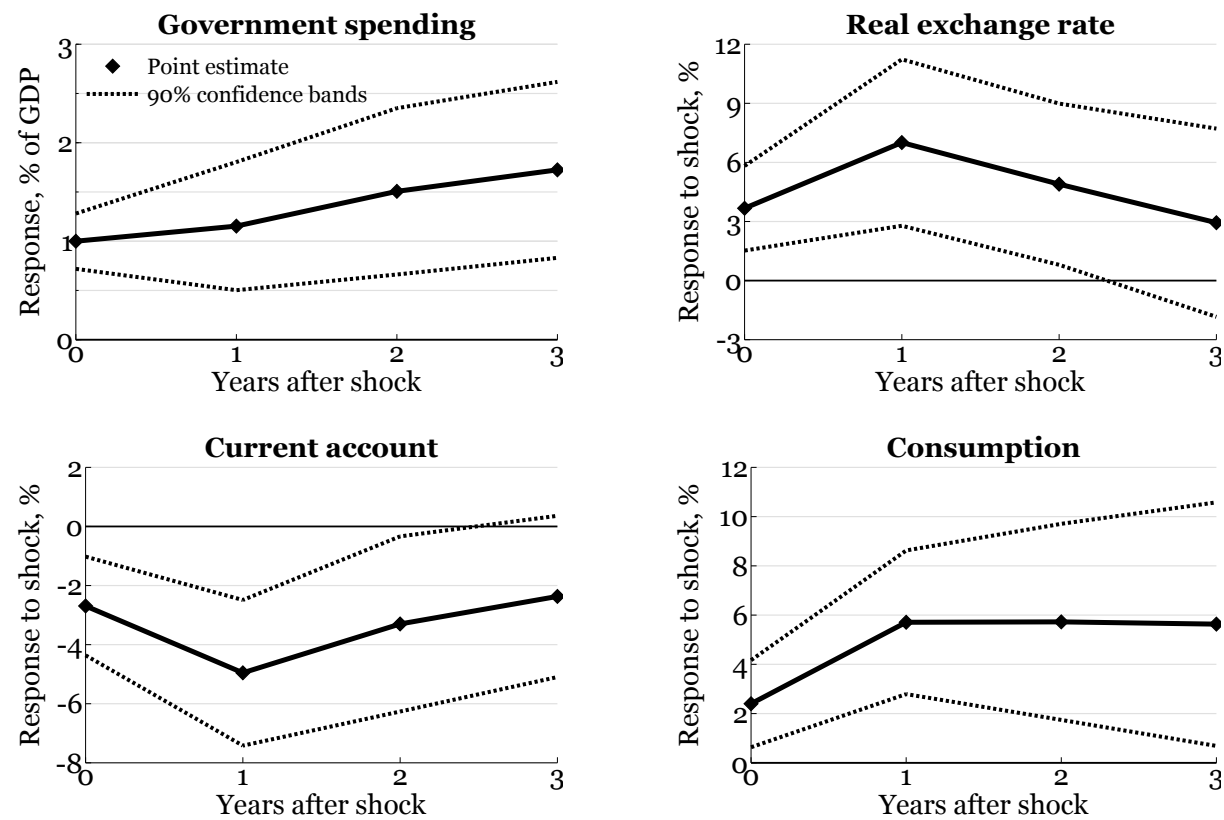

Notes: The responses of government spending, the real exchange rate, the current account, and consumption to an increase in government spending of 1 percent of GDP at horizons from 0 to 3 years. Government spending is instrumented by military spending. The dotted lines are the 90 percent confidence interval bounds.

\subsection{All Countries}

We present the estimated responses of the real exchange rate, current account, and consumption to an increase in government spending of 1 percent of GDP, using the full sample of 125 countries and the period between 1989 and 2013. We note that government spending is persistent, with a cumulative increase of about 1.2 percent of GDP at a one-year horizon, as plotted in the top left panel of Figure $2 .^{10}$

The top right panel of Figure 2 plots the effects of an increase in government spending of 1 percent of GDP on the REER in the baseline specification. The most important result in Figure 2 is that a positive shock to government spending leads to real exchange-rate appreciation. The estimates are large and statistically significant. The response of the REER is hump-shaped and significant up to a two-year horizon. A positive government-spending shock of 1 percent of GDP

\footnotetext{
${ }^{10}$ We also estimate the baseline specification using a limited information maximum likelihood (LIML) estimator. The results are similar.
} 
causes the real exchange rate to appreciate by 3.7 percent on impact, reaching its maximum of 7 percent over a one-year horizon. ${ }^{11}$ This result holds in several variations of Equation (1), for example, when we control for one lag of the unemployment rate. ${ }^{12}$

The bottom left plot in Figure 2 shows the response of the current account-to-GDP ratio. The current account deteriorates in response to an increase in government spending. The current accountto-output ratio decreases by 2 to 5 percentage points over a two-year horizon. The responses are statistically significant at horizons up to two years. ${ }^{13}$

The bottom right plot of Figure 2 shows the response of consumption to government-spending shocks. An increase in government spending of 1 percent of GDP leads to an increase in consumption of 2 percent on impact and of over 5 percent within two years. ${ }^{14}$

\subsection{Advanced vs. Developing Countries}

Next, we compare the responses of the real exchange rate, current account, and consumption in advanced and developing countries. We first estimate Equation (1) using the indicator function for each subsample. To test the difference between advanced and developing countries' responses, we estimate the following regression at each horizon $h=0,1,2$ :

$$
\begin{aligned}
\frac{x_{i, t+h}-x_{i, t-1}}{x_{i, t-1}}= & I^{A} \times\left(c^{A}+\alpha_{i}^{A}+\beta_{h}^{A} \frac{\Delta g_{i t}}{y_{i, t-1}}+\Phi^{x, A}(L) \frac{\Delta x_{i, t-1}}{x_{i, t-2}}+\Phi^{g, A}(L) \frac{\Delta g_{i, t-1}}{y_{i, t-2}}+\boldsymbol{\gamma}^{A \prime} \boldsymbol{z}_{i t}\right) \\
& +I^{D} \times\left(c^{D}+\alpha_{i}^{D}+\beta_{h}^{D} \frac{\Delta g_{i t}}{y_{i, t-1}}+\Phi^{x, D}(L) \frac{\Delta x_{i, t-1}}{x_{i, t-2}}+\Phi^{g, D}(L) \frac{\Delta g_{i, t-1}}{y_{i, t-2}}+\boldsymbol{\gamma}^{\boldsymbol{D}^{\prime}} \boldsymbol{z}_{i t}\right)+\varepsilon_{i t},
\end{aligned}
$$

where $I^{A}$ is the indicator for advanced countries and $I^{D}$ is the indicator for developing countries. The difference between the estimates for advanced and developing countries is given by $\beta_{h}^{A}-\beta_{h}^{D}$.

First, the responses of real exchange rates in advanced and developing countries are substantially different from each other. As plotted in the top right panel of Figure 3, while in developing countries the REER appreciates, advanced countries' REER depreciates at all horizons up to three years. ${ }^{15}$ The estimates for developing countries are statistically significant at horizons up to two

\footnotetext{
${ }^{11}$ Appendix Figure C1 shows a scatterplot of the coefficients from the regression of total spending on military spending (first stage) against the coefficients from the regression of the changes in real exchange rates on changes in military spending (second stage). The slope of the fitted lines highlights the following: There is heterogeneity across countries in the estimated relationship, with some negative relationship of the first-stage and second-stage regressions. Since the majority of dots in the figure are located in the northeast quadrant, we get a positive estimate for the baseline.

${ }^{12}$ Table C1 reports the results of several other estimation specifications. We also perform an additional check on the estimates by following Conley, Hansen, and Rossi (2012) and assuming that there is some possibility that the instrument may be "plausibly exogenous," that is, that the exclusion restriction can be relaxed so that Equation (1) includes a term $\gamma \Delta g_{i t}^{\mathrm{m}} / y_{i t-1}$. We obtain a union of confidence intervals for $\beta_{h}$ depending on the support of $\gamma$ for our baseline exchangerate specification up to 3 years after the shock. The union of 90 percent confidence intervals for $\beta_{h}$ does not include zero for $\gamma \in(-1,1)$. We thank our discussant Òscar Jordà for this suggestion.

${ }^{13}$ Similar to the REER case, we estimate several variations of the baseline specification, including the one with a lag of the unemployment rate. We find similar results, as detailed in Appendix Table C2. We also find that the net exports-toGDP ratio declines in response to an increase in government spending. The results are reported in Appendix Table C3.

${ }^{14}$ When we estimate other variations of the baseline specification, all the results in Appendix Table C4 suggest that after a positive government-spending shock, consumption increases substantially in the full sample.

${ }^{15}$ As the set of developing countries in our study is fairly large, one may suspect significant heterogeneity within this category. To check this, we split developing countries into middle- and low-income groups, based on their gross national
} 
Figure 3. Advanced vs. Developing Countries
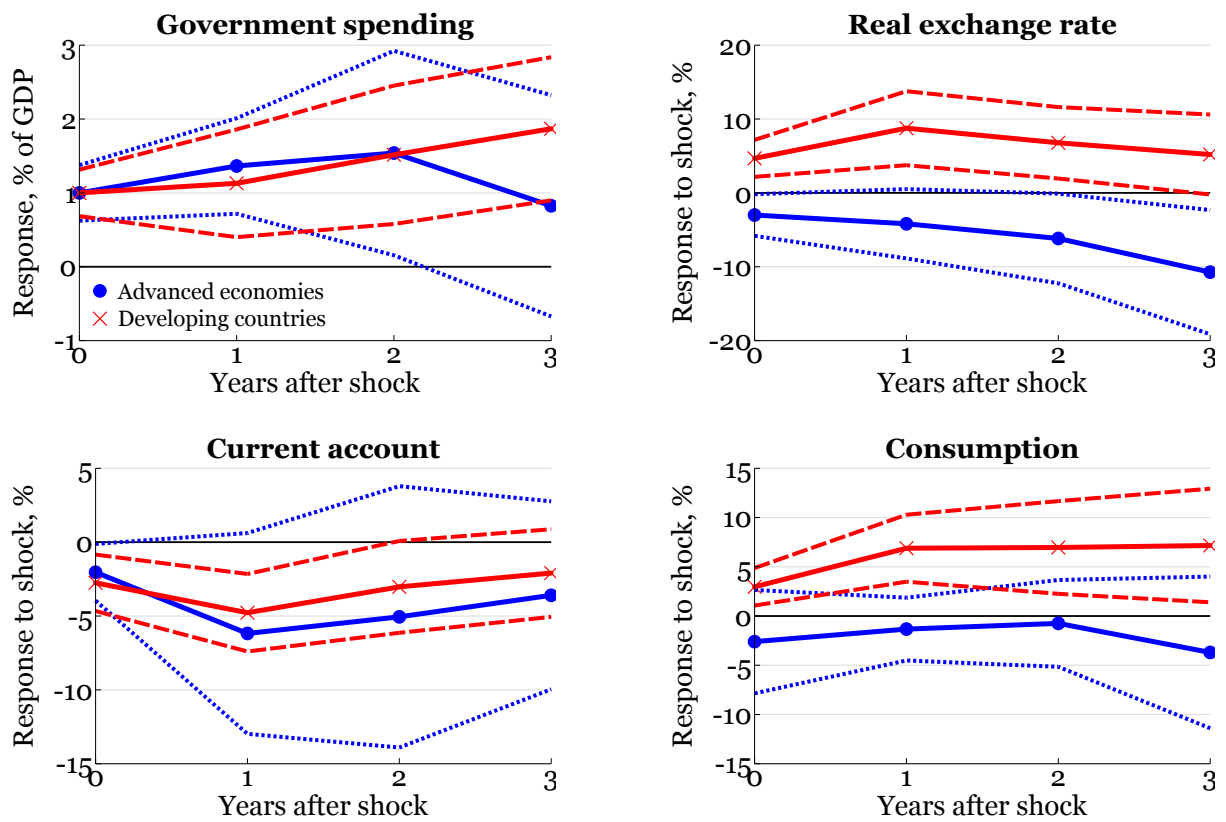

Notes: The responses of government spending, real exchange rates, the current account, and consumption to an increase in government spending of 1 percent of GDP in two groups of countries. Government spending is instrumented by military spending. The navy dotted lines and red dashed lines are the 90 percent confidence interval bounds for advanced and developing countries, respectively.

years, while the estimates for advanced countries are statistically significant on impact and at a two-year horizon. On impact, the REER in advanced countries depreciates by about 3 percent after an increase in government spending of 1 percent of GDP. In contrast, the REER in developing countries appreciates by about 4.7 percent on impact. The depreciation in advanced countries is approximately of the same magnitude as the appreciation in developing countries within a two-year horizon. However, in advanced countries, the REER response peaks at longer horizons than in developing countries, reaching its maximum, in absolute terms, of a 10 percent depreciation rate over a three-year horizon. Our finding that the REER depreciates in advanced countries is consistent with the previous literature that focuses on OECD countries, such as Monacelli and Perotti (2010) and Ravn, Schmitt-Grohé, and Uribe (2012), but contradicts to a recent paper by Auerbach and Gorodnichenko (2016), which finds appreciation of the real exchange rate in response to an increase in military spending in the United States. However, the fact that our confidence intervals for advanced countries are relatively large suggests that there is a high degree of heterogeneity across advanced countries. Columns (1) and (2) of Table 3 report the differences between the responses of REERs in advanced and developing countries, as well as the corresponding $p$-values. The responses of REERs in advanced countries are significantly smaller than those in developing countries, highlighting a stark contrast between these two groups. Finally, we note that the responses of government spend-

income in 2000. We do not find much support for heterogeneity. The estimates of REER responses for these two groups are similar to each other. Appendix Table C5 reports the estimates. Since the low-income countries coverage is relatively small, and real exchange rates appreciate in both low- and middle-income countries, we report the rest of the results for the two groups combined. 
Table 3. Differences between Advanced and Developing Countries

\begin{tabular}{|c|c|c|c|c|c|c|}
\hline \multirow[t]{2}{*}{ Horizon } & \multicolumn{2}{|c|}{ Real Exchange Rate } & \multicolumn{2}{|c|}{ Current Account } & \multicolumn{2}{|c|}{ Consumption } \\
\hline & $\begin{array}{c}\text { Difference } \\
\text { (1) }\end{array}$ & $\begin{array}{c}p \text {-value } \\
\text { (2) }\end{array}$ & $\begin{array}{c}\text { Difference } \\
\text { (3) }\end{array}$ & $\begin{array}{c}p \text {-value } \\
\text { (4) }\end{array}$ & $\begin{array}{c}\text { Difference } \\
\text { (5) }\end{array}$ & $\begin{array}{c}p \text {-value } \\
\text { (6) }\end{array}$ \\
\hline On impact & -7.67 & 0.00 & 0.71 & 0.66 & -5.57 & 0.10 \\
\hline 1 year & -12.94 & 0.00 & -1.40 & 0.75 & -8.21 & 0.00 \\
\hline 2 years & -12.95 & 0.01 & -2.03 & 0.72 & -7.71 & 0.05 \\
\hline 3 years & -15.93 & 0.01 & -1.51 & 0.72 & -10.86 & 0.06 \\
\hline
\end{tabular}

Notes: The differences are calculated by subtracting the responses in developing countries from those in advanced economies.

ing in both advanced and developing countries are similar to each other, as plotted in the top left panel of Figure 3. Government spending increases persistently in all countries by almost the same magnitude during the first two years; thus, government spending processes may not explain the differences in the responses across the two groups of countries.

The bottom left panel of Figure 3 shows that current accounts in both groups of countries decline substantially in response to the identified government-spending shocks. In other words, both advanced and developing countries increase borrowing. The estimated response of the current account in advanced countries is less precise than that in developing countries, and its 90 percent confidence interval is wide. We also test formally the difference between the responses of the current account in advanced and developing countries. As reported in columns (3) and (4) of Table 3, the $p$-values of the differences exceed conventional values at all horizons, so we cannot reject the null hypothesis that there is no difference between the responses of the current accounts in advanced and developing countries.

The consumption responses in advanced countries are different from those in developing countries. As reported in the bottom right panel of Figure 3, in advanced countries, consumption declines in response to an increase in government spending of 1 percent of GDP. The decrease in consumption in advanced countries is large, about 3 percent, corresponding to a multiplier of -1 on impact. The point estimate for advanced countries is different from that in previous papers such as Monacelli and Perotti (2010), which document an increase in consumption in a smaller number of countries. However, we note that the confidence bands of the advanced-countries estimates are wide and include zero, so it is difficult to draw a sharp conclusion about the responses of consumption in advanced countries. On the other hand, consumption increases significantly in developing countries. We report the differences in consumption responses in advanced and developing countries, as well as the $p$-values, in columns (5) and (6) of Table 3 . We can marginally reject the hypothesis that there is no difference between the consumption responses in the two groups of countries on impact (the $p$-value is 0.1 ). At horizons from one to three years, the differences in consumption responses in advanced and developing countries are statistically significant. ${ }^{16}$

\footnotetext{
${ }^{16}$ We estimate the responses of other important variables-inflation, government debt, and tax rates-to examine the transmission mechanism of government-spending shocks. However, since for most of the variables the results have wide confidence intervals, we leave them in Appendix Table C17. In particular, inflation declines in response to a governmentspending shock, although the decline is not statistically significant. Government debt responds significantly only in developing countries, and only on impact. In such cases, government debt falls. When we look at the response of tax rates separately, we find significantly positive responses only occasionally. However, the sample size of our data on tax
} 


\subsection{Exchange-Rate Regimes}

Since the effects of government spending can depend in theory on exchange-rate regimes, we estimate our baseline specification by grouping countries based on their exchange-rate regime. We use the Klein and Shambaugh (2008) classification to categorize exchange-rate regimes. We find that the responses of the real exchange rate, the current account, and consumption depend on an exchange-rate regime.

Panel A of Figure 4 shows estimates of the REER response separately for countries with fixed and flexible exchange-rate regimes. Under a fixed exchange rate, the REER response is not significantly different from zero. The same is true when we look at advanced and developing countries with a fixed exchange-rate regime: the responses of the REER in both groups are close to zero or negative, but insignificant at all considered horizons. Under a flexible exchange-rate regime, the REER response to an expansionary government-spending shock is positive, similar to the baseline response. We also find that advanced countries experience a significant depreciation of real exchange rates, whereas the reverse is true for developing countries. These results suggest that the estimates of the REER response are driven by countries with a flexible exchange-rate regime.

Panel B of Figure 4 displays the effects of government-spending shocks on the current accountto-output ratio under different exchange-rate regimes. For countries with a fixed exchange-rate regime, the current account deteriorates in response to a positive government-spending shock in both the advanced and developing countries subsamples, although the responses of the current account have wide confidence intervals. In the flexible exchange-rate regime, the current account deterioration is statistically significant in the full subsample, but this result is mostly driven by the developing countries. In advanced countries with a flexible exchange-rate regime, the responses of the current account are small and positive, but not significantly different from zero at all considered horizons.

Finally, the effects of government spending changes on consumption also depend on the exchangerate regime. As plotted in Panel C of Figure 4, point estimates of the responses of consumption are positive for both advanced and developing countries under a fixed exchange-rate regime. However, the responses are not significantly different from zero. On the other hand, the responses of consumption are similar to the baseline results when we restrict our attention to countries with a flexible exchange-rate regime only. In particular, consumption rises, on average. However, consumption increases only in developing countries, while it decreases in advanced countries under a flexible exchange-rate regime. This result, together with the results on the real exchange rate, suggests that our baseline results are disproportionately influenced by countries with a flexible exchange-rate regime. ${ }^{17}$

rates is significantly smaller than the size of the baseline sample.

${ }^{17}$ We note that the sizes of the samples of advanced countries under a fixed exchange-rate regime and of those under a flexible exchange-rate regime are similar to each other. The detailed results including the sample sizes and the $F$-statistics of the corresponding first-stage regressions are tabulated in Appendix Table C6. 
Figure 4. Fixed and Flexible Exchange-Rate Regimes

Panel A: Real exchange rates
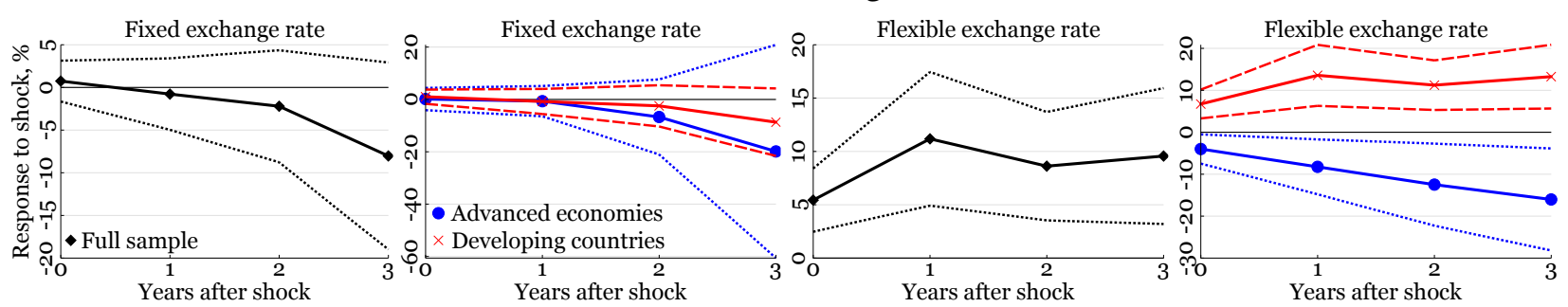

Panel B: Current account-to-GDP ratio
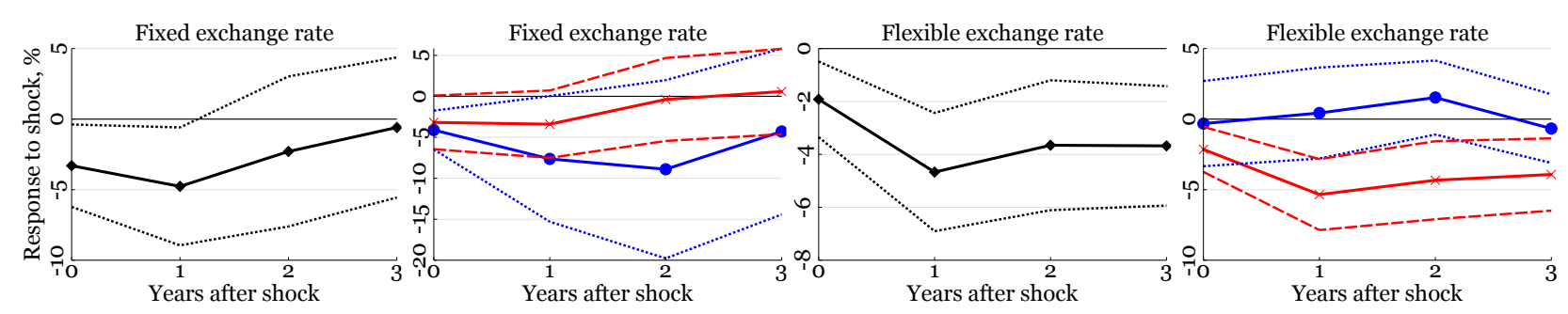

Panel C: Consumption
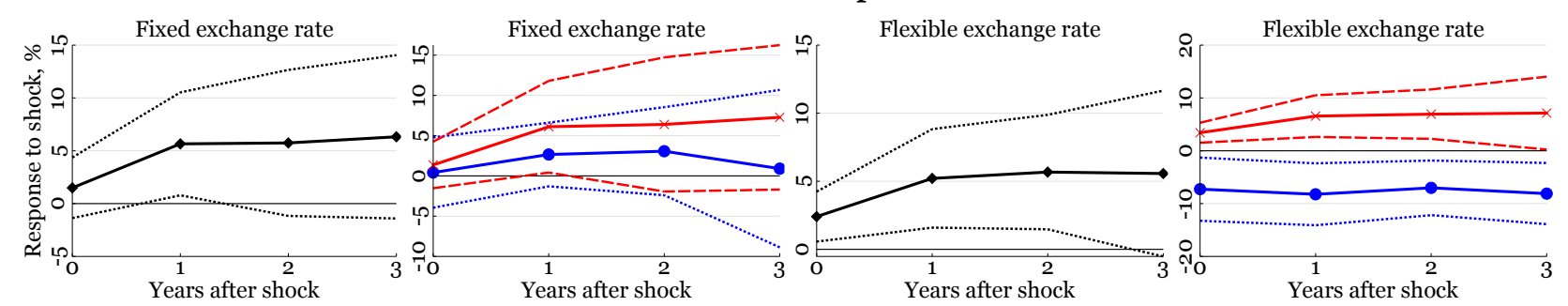

Notes: The responses of the real exchange rate, current account, and consumption to an increase in government spending of 1 percent of GDP, by exchange-rate regimes. The dotted and dashed lines are the 90 percent confidence interval bounds.

\subsection{Openness to Trade}

To examine whether the level of openness to trade affects the response of real exchange rates and current accounts to government-spending shocks, we re-estimate the baseline specification using subgroups of countries based on the combined shares of exports and imports in GDP. Following Ilzetzki, Mendoza, and Végh (2013), we calculate the average trade share in GDP for each country over the entire sample period. If the average trade share is above 60 percent of GDP, the country is classified as open. ${ }^{18}$ Figure 5 displays the responses of the real exchange rate, current account-to-output ratio, and consumption for different groups of countries. ${ }^{19}$ The responses of real exchange rates (Panel A) are similar in open and closed economies. On average, the real exchange rate appreciates, which is similar to the baseline results. Real exchange rates appreciate in developing countries and depreciate in advanced countries, regardless of whether the country is open or closed. In Panel B, the current account deteriorates in both open and closed economies regardless of the level of trade

\footnotetext{
${ }^{18}$ The results in this section do not change if we choose the classification based on the trade share at the midpoint of the sample period.

${ }^{19}$ Appendix Table C7 presents numerical estimates, along with sample sizes and first-stage $F$-statistics.
} 
Figure 5. Openness to Trade

Panel A: Real exchange rates
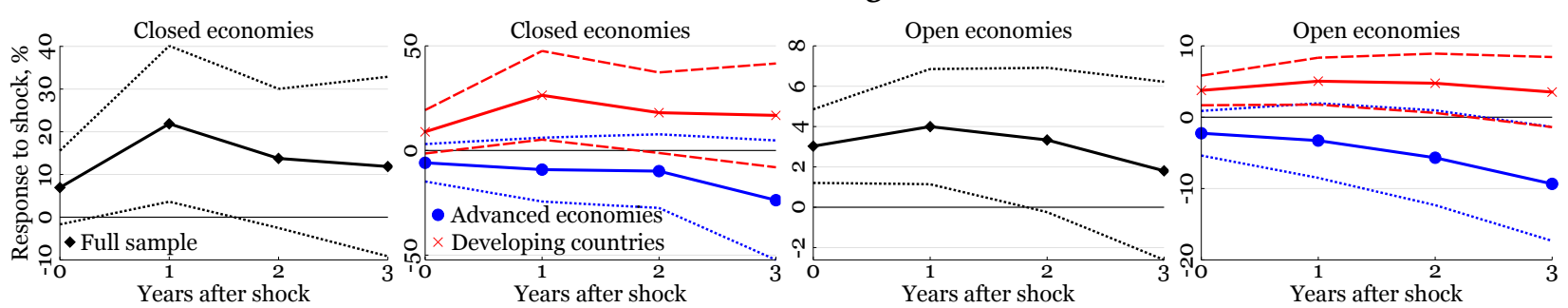

Panel B: Current account-to-GDP ratio
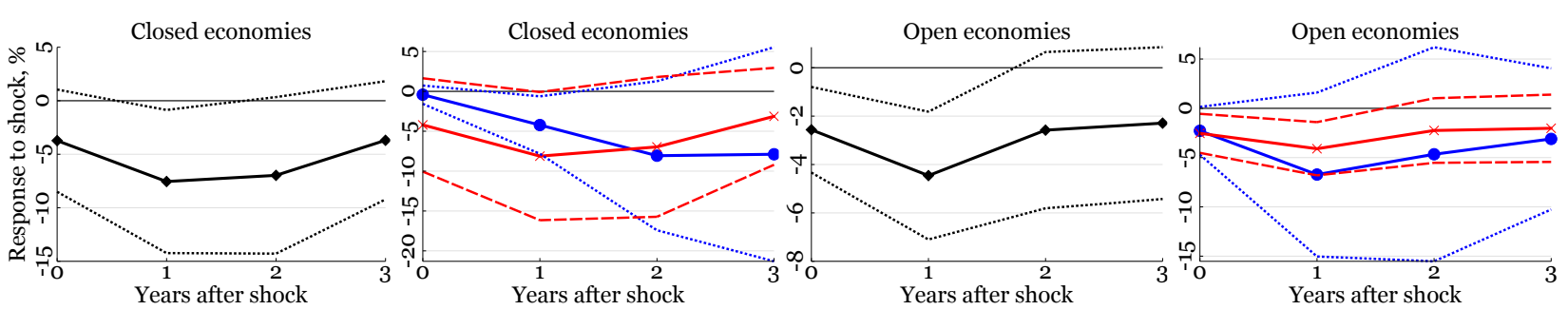

Panel C: Consumption
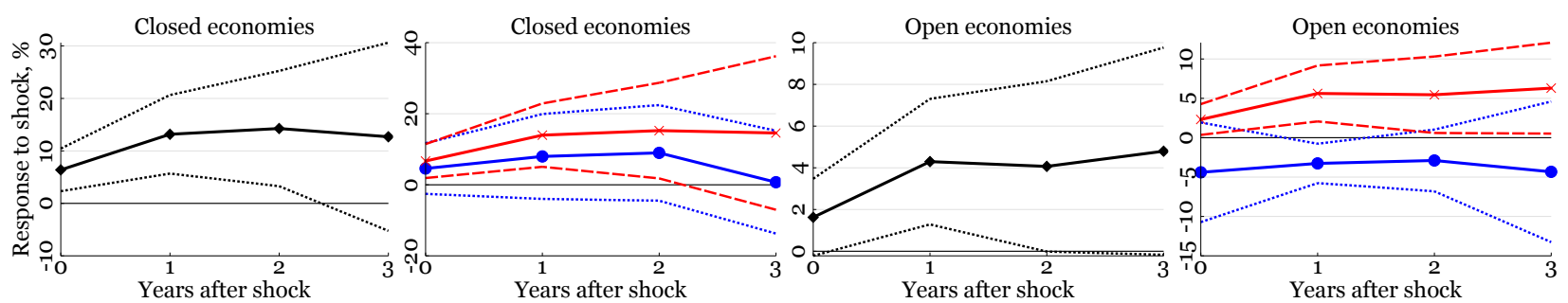

Notes: The responses of the real exchange rate, current account, and consumption to an increase in government spending of 1 percent of GDP, based on the level of openness measured by the total trade share in GDP. The dotted and dashed lines are the 90 percent confidence interval bounds.

openness. Finally, although consumption increases in both closed and open economies, on average, closed advanced countries increase their consumption in response to an expansionary governmentspending shock, whereas open advanced countries decrease their consumption, as shown in Panel C. Nevertheless, the estimates for advanced countries are less precise, with wide confidence intervals. These findings suggest that there is no strong evidence that openness to trade is important for the transmission mechanism of government-spending shocks.

Our results differ somewhat from the previous literature. Ilzetzki, Mendoza, and Végh (2013) report that that fiscal multipliers are larger in closed economies than in open economies. However, they do not consider the responses of the current account and the real exchange rate based on openness. Kim (2015) documents that the magnitude of the current account response is larger in open economies than in closed economies; however, in his paper, current accounts rise (not fall as in this paper and in Ilzetzki, Mendoza, and Végh 2013) in response to a government spending increase. In contrast, our results do not lend support to differential responses of current accounts or consumption based on trade openness. At the same time, we are in line with Kim (2015) on the similarity of REER responses in open and closed economies. 


\subsection{Robustness Checks}

This section examines important cases that can affect our baseline results. In particular, we analyze whether wars, financial crises, commodity prices, and the type of military spending can significantly influence our baseline results. We also show that our results are robust to adding potentially important controls to the regression.

Wars Our identification strategy relies on the fact that changes in military spending, especially those related to wars far from domestic soil, can be considered exogenous. However, this identification strategy may not work for wars associated with major human and capital losses. Although we drop from our baseline sample several countries with a long history of civil wars, such as Angola, Pakistan, Rwanda, and Sri Lanka, and then control for the average effects of wars, it is still possible that the baseline results are driven by special war periods in other countries in the sample. To address this possibility, we estimate Equation (1) excluding all war observations. Since the UCDP/PRIO war index includes both large conflicts, with more than 1,000 deaths a year, and small conflicts, with fewer than 1,000 deaths a year, and the index also captures civil wars as well as international border disputes, our exclusion of all war periods is conservative. ${ }^{20}$ The first three columns of Table 4 present the results for real exchange rates, current accounts, and consumption in this restricted sample. In general, the baseline results are robust. We find that while real exchange rates appreciate in developing countries at all considered horizons, the evidence from advanced countries is not conclusive, as the point estimates are not significant at conventional levels. Current accounts deteriorate in both groups of countries, and the estimates are statistically significant up to a one-year horizon. Consumption in developing countries increases significantly, in contrast to the negative and insignificant response in advanced countries. ${ }^{21}$

Financial Crises To the extent that financial crises put pressure on the government budget, financialcrisis episodes may also affect the exogeneity of military spending. Since our large data set includes several financial crisis episodes, we examine whether excluding these observations affects our results. The crisis dates are taken from Reinhart and Rogoff (2011). Similar to the war exercise, we exclude all observations that correspond to (i) banking crises (China 1996-99), (ii) currency crashes (South Africa, 2000-01), (iii) sovereign domestic (Argentina, 1989-90) or external (Paraguay, 2003-04) defaults/restructuring, (iv) inflation crises (Russia, 2001), and (v) stock market crashes (United States, 2000-01). The results are presented in columns (4)-(6) of Table 4. Most of the baseline results carry through. For example, current accounts decrease in all countries. The real exchange rate appreciates in developing countries, although the estimates are less precise, possibly due to a much smaller number of observations. One difference from the baseline result is that

\footnotetext{
${ }^{20}$ We note that the majority of wars in the data set are civil wars. There are few international border disputes (three observations), and since small disputes can lead to exogenous changes in military spending, we only exclude international border disputes with more than 1,000 deaths a year.

${ }^{21}$ In another robustness check, we exclude from our sample all countries with at least 10 years of civil war. These countries are Algeria, Burundi, Chad, Colombia, Ethiopia, India, Indonesia, Iran, Israel, Nepal, Peru, the Philippines, Russia, Thailand, Turkey, and Uganda. The results are similar to the baseline, as shown in Appendix Table C8.
} 
Table 4. Results Sensitivity to Sample Construction

\begin{tabular}{|c|c|c|c|c|c|c|c|c|c|c|c|c|}
\hline & \multicolumn{3}{|c|}{ No Wars } & \multicolumn{3}{|c|}{ No Financial Crises } & \multicolumn{3}{|c|}{ No Commodity Exporters } & \multicolumn{3}{|c|}{ No Arms Importers } \\
\hline & $\begin{array}{l}\text { All } \\
\text { (1) }\end{array}$ & $\begin{array}{c}\text { Adv } \\
(2)\end{array}$ & $\begin{array}{l}\text { Dev } \\
(3)\end{array}$ & $\begin{array}{l}\text { All } \\
\text { (4) }\end{array}$ & $\begin{array}{c}\text { Adv } \\
\text { (5) }\end{array}$ & $\begin{array}{c}\text { Dev } \\
(6)\end{array}$ & $\begin{array}{l}\text { All } \\
(7)\end{array}$ & $\begin{array}{c}\text { Adv } \\
\text { (8) }\end{array}$ & $\begin{array}{c}\text { Dev } \\
(9)\end{array}$ & $\begin{array}{l}\text { All } \\
(10\end{array}$ & $\begin{array}{l}\text { Adv } \\
(11)\end{array}$ & $\begin{array}{l}\text { Dev } \\
(12)\end{array}$ \\
\hline \multicolumn{13}{|c|}{ Panel A: Real exchange rates } \\
\hline On impact & $\begin{array}{c}4.16^{* * *} \\
(1.46)\end{array}$ & $\begin{array}{l}-2.95 \\
(2.27)\end{array}$ & $\begin{array}{c}5.05^{\text {**** }} \\
(1.68)\end{array}$ & $\begin{array}{c}0.77 \\
(3.82)\end{array}$ & $\begin{array}{c}-10.27 \\
(8.26)\end{array}$ & $\begin{array}{c}4.00 \\
(4.85)\end{array}$ & $\begin{array}{c}1.21 \\
(1.37)\end{array}$ & $\begin{array}{c}-5.63^{* * *} \\
(1.84)\end{array}$ & $\begin{array}{c}2.55 \\
(1.59)\end{array}$ & $\begin{array}{c}5.54^{* * *} \\
(1.73)\end{array}$ & $\begin{array}{r}* 3.18 \\
(3.34)\end{array}$ & $\begin{array}{c}6.38^{* * *} \\
(1.93)\end{array}$ \\
\hline 1 year & $\begin{array}{c}5.93^{* *} \\
(2.42)\end{array}$ & $\begin{array}{c}-3.88 \\
(3.73)\end{array}$ & $\begin{array}{c}7.24^{* *} \\
(2.84)\end{array}$ & $\begin{array}{c}3.11 \\
(4.92)\end{array}$ & $\begin{array}{c}-6.34 \\
(9.02)\end{array}$ & $\begin{array}{c}6.63 \\
(6.20)\end{array}$ & $\begin{array}{r}4.32^{*} \\
(2.53)\end{array}$ & $\begin{array}{c}-8.42^{* *} \\
(2.97)\end{array}$ & $\begin{array}{c}6.66^{* *} \\
(3.08)\end{array}$ & $\begin{array}{l}11.54^{* *} \\
(4.01)\end{array}$ & $\begin{array}{c}-3.55 \\
(5.47)\end{array}$ & $\begin{array}{l}12.98^{* * *} \\
(4.47)\end{array}$ \\
\hline 2 years & $\begin{array}{c}4.89^{*} \\
(2.82)\end{array}$ & $\begin{array}{c}-5.10 \\
(4.61)\end{array}$ & $\begin{array}{c}6.30^{*} \\
(3.30)\end{array}$ & $\begin{array}{c}-3.50 \\
(5.70)\end{array}$ & $\begin{array}{c}-11.21 \\
(12.17)\end{array}$ & $\begin{array}{c}0.43 \\
(6.58)\end{array}$ & $\begin{array}{c}3.47 \\
(2.99)\end{array}$ & $\begin{array}{c}-11.45^{* * *} \\
(3.84)\end{array}$ & $\begin{array}{r}6.22^{*} \\
(3.59)\end{array}$ & $\begin{array}{c}8.87^{* *} \\
(3.55)\end{array}$ & $\begin{array}{c}-4.76 \\
(6.81)\end{array}$ & $\begin{array}{l}10.31^{* *} \\
(4.02)\end{array}$ \\
\hline 3 years & $\begin{array}{c}3.44 \\
(3.36)\end{array}$ & $\begin{array}{c}-9.64 \\
(6.82)\end{array}$ & $\begin{array}{c}5.14 \\
(3.78)\end{array}$ & $\begin{array}{c}-6.64 \\
(7.54)\end{array}$ & $\begin{array}{r}-19.88 \\
(17.22)\end{array}$ & $\begin{array}{c}-1.12 \\
(8.61)\end{array}$ & $\begin{array}{c}2.25 \\
(3.89)\end{array}$ & $\begin{array}{c}-19.46^{* *} \\
(6.79)\end{array}$ & $\begin{array}{c}6.17 \\
(4.57)\end{array}$ & $\begin{array}{c}4.79 \\
(3.87)\end{array}$ & $\begin{array}{c}-9.85 \\
(11.50)\end{array}$ & $\begin{array}{c}6.10 \\
(4.09)\end{array}$ \\
\hline First-stage $F$ & 25.4 & 17.9 & 20.3 & 23.6 & 4.5 & 17.8 & 18.4 & 27.5 & 13.3 & 16.5 & 13.1 & 13.9 \\
\hline Obs. & 2,058 & 619 & 1,439 & 569 & 259 & 310 & 1,692 & 565 & 1,127 & 1,911 & 450 & 1,461 \\
\hline \multicolumn{13}{|c|}{ Panel B: Current account-to-GDP ratio } \\
\hline On impact & $\begin{array}{c}-2.93^{\text {**** }} \\
(1.06)\end{array}$ & $\begin{array}{c}-2.68^{\text {*** }}(1.37)\end{array}$ & $\begin{array}{c}-2.90^{* *} \\
(1.18)\end{array}$ & $\begin{array}{c}-4.76^{* *} \\
(2.12)\end{array}$ & $\begin{array}{c}-5.57 \\
(4.71)\end{array}$ & $\begin{array}{c}-4.67^{*} \\
(2.46)\end{array}$ & $\begin{array}{r}-1.51^{*} \\
(0.79)\end{array}$ & $\begin{array}{c}-0.76 \\
(1.12)\end{array}$ & $\begin{array}{r}-1.64^{*} \\
(0.90)\end{array}$ & $\begin{array}{c}-3.34^{* *} \\
(1.49)\end{array}$ & $\begin{array}{c}-3.50^{* * *} \\
(1.27)\end{array}$ & $\begin{array}{c}*-3.30^{* *} \\
(1.61)\end{array}$ \\
\hline 1 year & $\begin{array}{c}-4.90^{* *} \\
(1.58)\end{array}$ & $\begin{array}{r}-8.44^{*} \\
(4.92)\end{array}$ & $\begin{array}{c}-4.41^{* *} \\
(1.60)\end{array}$ & $\begin{array}{c}-9.71^{* *} \\
(4.24)\end{array}$ & $\begin{array}{r}-11.26^{*} \\
(6.63)\end{array}$ & $\begin{array}{r}-9.40^{*} \\
(5.19)\end{array}$ & $\begin{array}{r}-3.20^{*} \\
(1.64)\end{array}$ & $\begin{array}{c}-0.50 \\
(1.46)\end{array}$ & $\begin{array}{c}-3.75^{* *} \\
(1.90)\end{array}$ & $\begin{array}{c}-7.37^{* *} \\
(2.11)\end{array}$ & $\begin{array}{c}-9.54 \\
(7.78)\end{array}$ & $\begin{array}{c}-7.01^{* * *} \\
(2.10)\end{array}$ \\
\hline 2 years & $\begin{array}{c}-2.81 \\
(1.85)\end{array}$ & $\begin{array}{c}-7.15 \\
(6.84)\end{array}$ & $\begin{array}{c}-2.20 \\
(1.82)\end{array}$ & $\begin{array}{c}-9.11^{* *} \\
(3.59)\end{array}$ & $\begin{array}{c}-6.47 \\
(6.71)\end{array}$ & $\begin{array}{c}-9.89^{* *} \\
(4.18)\end{array}$ & $\begin{array}{r}-2.82^{*} \\
(1.61)\end{array}$ & $\begin{array}{c}0.31 \\
(2.68)\end{array}$ & $\begin{array}{r}-3.42^{*} \\
(1.83)\end{array}$ & $\begin{array}{r}-5.68^{*} \\
(2.95)\end{array}$ & $\begin{array}{l}-9.37 \\
(10.02)\end{array}$ & $\begin{array}{r}-5.04^{*} \\
(2.91)\end{array}$ \\
\hline 3 years & $\begin{array}{c}-1.71 \\
(1.67)\end{array}$ & $\begin{array}{c}-5.56 \\
(5.18)\end{array}$ & $\begin{array}{c}-1.14 \\
(1.72)\end{array}$ & $\begin{array}{c}-6.43^{* *} \\
(2.57)\end{array}$ & $\begin{array}{c}-3.60 \\
(5.18)\end{array}$ & $\begin{array}{c}-7.31^{* *} \\
(2.85)\end{array}$ & $\begin{array}{c}-2.08 \\
(1.87)\end{array}$ & $\begin{array}{c}-0.58 \\
(2.29)\end{array}$ & $\begin{array}{c}-2.19 \\
(2.10)\end{array}$ & $\begin{array}{r}-4.24^{*} \\
(2.49)\end{array}$ & $\begin{array}{c}-8.01 \\
(7.49)\end{array}$ & $\begin{array}{c}-3.54 \\
(2.47)\end{array}$ \\
\hline First-stage $F$ & 28.8 & 38.0 & 23.0 & 29.8 & 4.4 & 24.9 & 21.1 & 29.0 & 15.5 & 17.7 & 38.7 & 14.8 \\
\hline Obs. & 2,090 & 605 & 1,485 & 583 & 259 & 324 & 1,720 & 553 & 1,167 & 1,953 & 442 & 1,511 \\
\hline \multicolumn{13}{|c|}{ Panel C: Consumption } \\
\hline On impact & $\begin{array}{c}2.72^{* *} \\
(1.21)\end{array}$ & $\begin{array}{c}-2.52 \\
(4.55)\end{array}$ & $\begin{array}{c}3.21^{* *} \\
(1.27)\end{array}$ & $\begin{array}{c}3.36 \\
(2.09)\end{array}$ & $\begin{array}{c}1.42 \\
(1.83)\end{array}$ & $\begin{array}{c}3.93 \\
(2.75)\end{array}$ & $\begin{array}{c}3.00^{* *} \\
(1.45)\end{array}$ & $\begin{array}{r}-4.27 \\
(3.00)\end{array}$ & $\begin{array}{c}4.02^{* *} \\
(1.67)\end{array}$ & $\begin{array}{c}2.59^{*} \\
(1.43)\end{array}$ & $\begin{array}{c}-6.86^{* * *} \\
(2.51)\end{array}$ & $\begin{array}{c}* 3.45^{* *} \\
(1.56)\end{array}$ \\
\hline 1 year & $\begin{array}{c}5.69^{* *} \\
(1.99)\end{array}$ & $\begin{array}{c}-0.31 \\
(2.34)\end{array}$ & $\begin{array}{c}6.66^{* *} \\
(2.31)\end{array}$ & $\begin{array}{c}2.67 \\
(2.76)\end{array}$ & $\begin{array}{c}6.30^{* *} \\
(2.93)\end{array}$ & $\begin{array}{c}1.96 \\
(3.40)\end{array}$ & $\begin{array}{c}6.23^{* *} \\
(2.29)\end{array}$ & $\begin{array}{c}-1.85 \\
(3.56)\end{array}$ & $\begin{array}{l}7.30^{* * *} \\
(2.65)\end{array}$ & $\begin{array}{c}8.00^{* *} \\
(2.82)\end{array}$ & $\begin{array}{c}-1.96 \\
(2.35)\end{array}$ & $\begin{array}{l}9.05^{* * *} \\
(3.13)\end{array}$ \\
\hline 2 years & $\begin{array}{c}6.34^{* *} \\
(2.80)\end{array}$ & $\begin{array}{c}0.71 \\
(3.16)\end{array}$ & $\begin{array}{c}7.41^{* *} \\
(3.27)\end{array}$ & $\begin{array}{c}3.70 \\
(3.83)\end{array}$ & $\begin{array}{c}7.03^{*} \\
(3.92)\end{array}$ & $\begin{array}{c}3.04 \\
(4.72)\end{array}$ & $\begin{array}{c}5.63^{* *} \\
(2.64)\end{array}$ & $\begin{array}{c}-2.03 \\
(4.86)\end{array}$ & $\begin{array}{c}6.63^{* *} \\
(3.02)\end{array}$ & $\begin{array}{c}8.01^{* *} \\
(4.08)\end{array}$ & $\begin{array}{r}-4.53^{*} \\
(2.63)\end{array}$ & $\begin{array}{c}9.53^{* *} \\
(4.62)\end{array}$ \\
\hline 3 years & $\begin{array}{l}7.08^{* *} \\
(3.43)\end{array}$ & $\begin{array}{c}-3.10 \\
(6.49)\end{array}$ & $\begin{array}{c}8.58^{* *} \\
(3.94)\end{array}$ & $\begin{array}{c}2.99 \\
(4.36)\end{array}$ & $\begin{array}{c}-0.39 \\
(4.25)\end{array}$ & $\begin{array}{c}4.17 \\
(5.47)\end{array}$ & $\begin{array}{c}3.02 \\
(3.36)\end{array}$ & $\begin{array}{r}-7.16^{*} \\
(4.18)\end{array}$ & $\begin{array}{c}4.33 \\
(3.88)\end{array}$ & $\begin{array}{c}9.04^{*} \\
(4.98)\end{array}$ & $\begin{array}{c}-15.20^{* *} \\
(4.50)\end{array}$ & $\begin{array}{l}11.17^{* *} \\
(5.55)\end{array}$ \\
\hline First-stage $F$ & 26.2 & 18.9 & 21.1 & 23.2 & 4.7 & 17.3 & 22.1 & 11.6 & 16.5 & 18.8 & 24.8 & 16.3 \\
\hline Obs. & 2,122 & 620 & 1,502 & 580 & 259 & 321 & 1,757 & 565 & 1,192 & 1,995 & 453 & 1,542 \\
\hline
\end{tabular}

Notes: This table reports the response of the real exchange rate, current account-to-GDP ratio, and consumption to an expansionary $g$ shock of 1 percent of GDP "Adv" denotes the advanced-countries sample, "Dev" denotes the developing-countries sample. The $g$ shocks are constructed using military spending as an instrument for total government spending. In the first three columns, we drop countries at war from the sample. In the next three columns, we do the same for financial crises periods. Results in columns (7) to (9) are based on the exclusion of commodity exporters. Finally, the last three columns present results for the case when countries with a large share of military spending on armed imports are excluded. 
consumption increases significantly in advanced countries at one- and two-year horizons, whereas consumption decreases insignificantly in the baseline. This result suggests that there might be a large degree of heterogeneity across advanced countries. Since the number of observations falls tremendously when we drop the observations with financial crises, we also examine a case where we control for the effects of financial crises by adding a dummy variable to the baseline specification. The results of this case, reported in Appendix Table C9, are in line with the baseline estimates.

Commodity Exporters Another concern about our data set is that some countries are major commodity exporters, whose public budgets and military spending may depend on commodity prices. For example, Chile's Copper Law mandates that 10 percent of the country's export revenues from copper be spent on the military. As a result, higher copper prices may lead to an increase in military spending that coincides with real exchange-rate appreciation, the strengthening of the current account, and an increase in consumption. We, therefore, exclude from our sample countries where the median share of commodities in total exports is above 50 percent. $^{22}$ In total, we exclude 38 countries. These countries are major exporters of oil, such as Nigeria, Russia, Saudi Arabia, United Arab Emirates, Venezuela, metals (Chile, copper), food (Burundi, coffee beans; Paraguay, soy beans), and other commodities (Burkina Faso, cotton). The results are presented in columns (7) to (9) of Table 4, and are mostly in accord with the benchmark. This exclusion restriction is conservative. When we use a stronger exclusion criterion of having the share of exported oil and metals above 15 percent of GDP, the results are even closer to the baseline (Table C11 in the appendix).

Military Imports We also explore the role of military imports in the transmission mechanism of fiscal policy. Standard macroeconomic models give robust predictions about the exchange-rate effects of an increase in government spending directed to domestic products. This exercise is consistent with the common practice of spending public money on domestic infrastructure, health care, education, and so on. The military budgets of many countries, however, have a significant component of spending directed to foreign goods, since relatively few countries produce arms and military equipment themselves. In theory, when the government demands more foreign goods than domestic goods, the price of foreign goods relative to the price of domestic goods increases, so the real exchange rate depreciates. The reverse is true if the government demands more domestic goods.

To understand whether such alternative mechanisms can explain our results, we merge our data set with the U.S. Department of State's World Military Expenditures and Arms Transfers (WMEAT) 2015 data. The WMEAT data contain detailed information about military expenditures and imports during the period 2002-2012. We construct countries' individual series of the share of imports in military spending by dividing imported arms deliveries by total military expenditures. We find

\footnotetext{
${ }^{22}$ To measure the commodities share in total exports, we use two data sources: (1) the U.N. Conference on Trade and Development (UNCTAD), and (2) Comtrade database. Despite some differences between the two data sets, the resulting lists of commodity exporters are almost identical. In two cases, the share is above 50 percent in Comtrade but not in UNCTAD (Indonesia, Nicaragua), and in one case, the opposite is true (the United Arab Emirates). To be conservative, these three countries are among the excluded 38 countries. The full list of excluded commodity exporters can be found in Appendix Table C10.
} 
Figure 6. Responses to Military Spending Shocks: Durable and Nondurable Military Spending
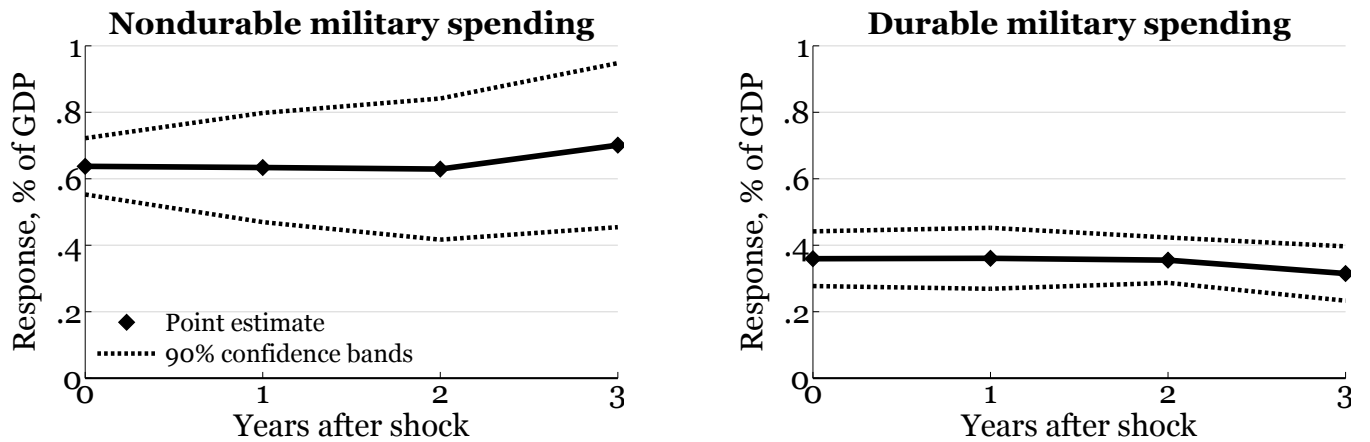

Notes: The responses of durable and nondurable military spending to an increase in military spending of 1 percent of GDP. The dotted lines are the 90 percent confidence interval bound.

that in most countries, the average share of arms imports in military spending is 18 percent or less. However, there are a handful of countries with a large share of arms imports in military spending (for example, Egypt, over 50 percent), and therefore these extreme observations may have a disproportionate influence on our baseline results. ${ }^{23}$ To address this problem, in columns (10) to (12), we exclude all countries with a fraction of over 25 percent in an average year. ${ }^{24}$ The results of this exercise confirm our baseline findings.

As another check, we investigate what components of military spending contribute to the shocks. The SIPRI data allow grouping military spending into four categories: equipment, infrastructure, personnel, and operational expenses. It is customary to treat the first two categories as consumption of durables, and the last two as nondurables. In our context, spending on nondurables is much more likely to have an effect domestically than spending on durables, which may be directed largely abroad. We then estimate the responses of these two components to an increase in military spending. ${ }^{25}$ The results plotted in Figure 6 suggest that not only durable but also nondurable military spending increases; thus, it is unlikely that military imports drive the results.

International Aid In many developing countries, government spending is funded to some extent by foreign aid. Aid-financed government spending may lead to effects different from tax- or debtfinanced government spending. For example, the wealth effect may be negligible in this case, since government spending due to aid does not lead to higher taxes in the present or in the future, nor does it affect consumers' expectations. To address this issue, we test the sensitivity of our results to dropping from the baseline sample countries that receive a significant amount of aid. As the data on bilateral aid are not available for a large number of countries, we drop countries that

\footnotetext{
${ }^{23}$ Figure C2 in the appendix plots the distribution of the average shares of arms imports in military spending in the full sample.

${ }^{24}$ These countries are Bahrain, Canada, Cape Verde, Egypt, Georgia, Guyana, Israel, Jordan, Laos, Luxembourg, Mexico, the Seychelles, Singapore, and the United Arab Emirates. The results are the same if we set the threshold at 40 percent, if we use the median share, or we drop countries with at least one annual share above 70 percent (Appendix Table C12). These thresholds also cut off the countries where arms deliveries in one year exceed 100 percent of military spending.

${ }^{25}$ Essentially, this strategy produces a decomposition of the military spending shock into durable and nondurable components.
} 
receive substantial aid from World Bank development projects. Using internal World Bank data, Kraay (2012) identifies 29 countries that received substantial aid in the period 1985-2009, which roughly matches our sample period. Table C13 in the appendix presents the estimates of our baseline equation when we drop 21 of such countries that are also present in our sample. ${ }^{26}$

Anticipated Spending One potential concern about our methodology is that we do not explicitly control for anticipated changes in military spending, which can have different effects on the economy compared with unanticipated changes. Since our sample consists of over a hundred countries, obtaining a forecast measure of military spending is difficult. However, we attempt to control for anticipated changes in military spending by adding a measure of political risks to the control variables. We use the political risk index from The International Country Risk Guide, which has published monthly data for over 140 countries since 1980. The index rates a country in a given period based on the assessment of external and internal risks, as well as of the degree of military influence in the government. A higher risk rating may indicate that people expect military spending to change in the future. We include this index in the control set and re-estimate Equation (1). The first three columns of Table 5 suggest that our results are robust to adding this control variable.

Monetary Policy and Common Shocks Our next robustness exercises pertain to the roles monetary policy, interest rates, and common shocks play in fiscal transmission. First, since monetary policy can affect the transmission mechanism of government-spending shocks, we add a policy rate to our baseline specification, and re-estimate the effects of government spending on the real exchange rate, current account, and consumption. Columns (4)-(6) of Table 5 present the results. Quantitatively, the baseline results stand, although the confidence intervals become wider. Second, to address the possibility that there are common shocks affecting the world economy, we include time fixed-effects in the control variables and re-estimate Equation (1). The results in the last three columns of Table 5 are similar to the baseline results. We note that in another robustness check, reported in Table C14 in the Appendix, we control for global military spending and find that the results are similar to the baseline. ${ }^{27}$ Third, since the 2008 Global Financial Crisis (GFC), nominal interest rates have remained at, or close to, zero in many countries. Naturally, there is a concern that the responses of the REER, consumption, and the current account to government-spending shocks could change around 2008. To address this possibility, we produce estimates of the responses in the period 1989-2007, excluding the GFC and its aftermath. Table C15 in the appendix shows that our results for the REER, consumption, and the current account are not affected by the recent episode of the Great Recession and the zero lower bound. The estimates are statistically significant and

\footnotetext{
${ }^{26}$ The excluded countries are Bolivia, Burkina Faso, Burundi, Cape Verde, Chad, Côte d'Ivoire, Ethiopia, Ghana, Jordan, Kenya, Lesotho, Madagascar, Malawi, Mali, Morocco, Senegal, Sierra Leone, Tanzania, Tunisia, Uganda, and Zambia. Foreign aid recipients that are not in our sample include Benin, the Central African Republic, the Comoros, Gambia, Guinea, Niger, Rwanda, and Togo.

${ }^{27}$ The global military spending data are also taken from SIPRI.
} 
Table 5. Results Sensitivity to Additional Controls

\begin{tabular}{|c|c|c|c|c|c|c|c|c|c|}
\hline & \multicolumn{3}{|c|}{ Political Risk } & \multicolumn{3}{|c|}{ Monetary Policy Rate } & \multicolumn{3}{|c|}{ Time Fixed Effects } \\
\hline & $\begin{array}{l}\text { All } \\
\text { (1) }\end{array}$ & $\begin{array}{c}\text { Adv } \\
(2)\end{array}$ & $\begin{array}{c}\text { Dev } \\
\text { (3) }\end{array}$ & $\begin{array}{l}\text { All } \\
(4)\end{array}$ & $\begin{array}{c}\text { Adv } \\
\text { (5) }\end{array}$ & $\begin{array}{c}\text { Dev } \\
(6)\end{array}$ & $\begin{array}{l}\text { All } \\
\text { (7) }\end{array}$ & $\begin{array}{l}\text { Adv } \\
\text { (8) }\end{array}$ & $\begin{array}{l}\text { Dev } \\
(9)\end{array}$ \\
\hline \multicolumn{10}{|c|}{ Panel A: Real exchange rates } \\
\hline On impact & $\begin{array}{c}3.63^{* *} \\
(1.49)\end{array}$ & $\begin{array}{r}-2.97^{*} \\
(1.72)\end{array}$ & $\begin{array}{l}4.98^{* * *} \\
(1.80)\end{array}$ & $\begin{array}{c}3.50 \\
(2.85)\end{array}$ & $\begin{array}{c}-5.36^{* *} \\
(2.08)\end{array}$ & $\begin{array}{c}6.06 \\
(3.90)\end{array}$ & $\begin{array}{l}3.77^{\text {*** }} \\
(1.36)\end{array}$ & $\begin{array}{c}-2.08 \\
(2.50)\end{array}$ & $\begin{array}{l}5.04^{* * *} \\
(1.64)\end{array}$ \\
\hline 1 year & $\begin{array}{c}6.73^{* *} \\
(2.76)\end{array}$ & $\begin{array}{c}-3.89 \\
(2.82)\end{array}$ & $\begin{array}{c}8.94^{* *} \\
(3.36)\end{array}$ & $\begin{array}{c}3.90 \\
(2.97)\end{array}$ & $\begin{array}{c}-9.01^{* *} \\
(3.37)\end{array}$ & $\begin{array}{c}7.51^{*} \\
(3.93)\end{array}$ & $\begin{array}{c}7.17^{* *} \\
(2.75)\end{array}$ & $\begin{array}{c}-4.07 \\
(4.22)\end{array}$ & $\begin{array}{c}9.54^{* * *} \\
(3.37)\end{array}$ \\
\hline 2 years & $\begin{array}{c}3.84 \\
(2.54)\end{array}$ & $\begin{array}{c}-5.72 \\
(3.63)\end{array}$ & $\begin{array}{c}6.03^{* *} \\
(2.99)\end{array}$ & $\begin{array}{c}1.92 \\
(3.80)\end{array}$ & $\begin{array}{c}-13.41^{* * *} \\
(4.74)\end{array}$ & $\begin{array}{c}6.68 \\
(4.67)\end{array}$ & $\begin{array}{c}5.50^{* *} \\
(2.68)\end{array}$ & $\begin{array}{c}-8.00 \\
(6.07)\end{array}$ & $\begin{array}{c}8.35^{* *} \\
(3.36)\end{array}$ \\
\hline 3 years & $\begin{array}{c}1.70 \\
(2.89)\end{array}$ & $\begin{array}{r}-10.25^{* *} \\
(5.04)\end{array}$ & $\begin{array}{c}4.20 \\
(3.19)\end{array}$ & $\begin{array}{c}0.19 \\
(4.52)\end{array}$ & $\begin{array}{c}-22.80^{* *} \\
(8.75)\end{array}$ & $\begin{array}{c}6.49 \\
(5.10)\end{array}$ & $\begin{array}{c}3.21 \\
(3.11)\end{array}$ & $\begin{array}{r}-11.01 \\
(7.73)\end{array}$ & $\begin{array}{c}5.86 \\
(3.80)\end{array}$ \\
\hline First-stage $F$ & 24.5 & 19.3 & 17.7 & 7.5 & 44.1 & 4.7 & 28.3 & 15.1 & 20.7 \\
\hline Obs. & 2,038 & 635 & 1,403 & 1,475 & 579 & 896 & 2,354 & 643 & 1,711 \\
\hline \multicolumn{10}{|c|}{ Panel B: Current account-to-GDP ratio } \\
\hline On impact & $\begin{array}{c}-2.94^{* *} \\
(1.25)\end{array}$ & $\begin{array}{r}-2.21^{*} \\
(1.15)\end{array}$ & $\begin{array}{c}-3.03^{* *} \\
(1.50)\end{array}$ & $\begin{array}{c}-4.60^{* *} \\
(2.30)\end{array}$ & $\begin{array}{c}-2.12 \\
(1.65)\end{array}$ & $\begin{array}{r}-5.26^{*} \\
(2.97)\end{array}$ & $\begin{array}{c}-2.92^{* * *} \\
(1.03)\end{array}$ & $\begin{array}{c}-2.32 \\
(1.58)\end{array}$ & $\begin{array}{c}-3.01^{* *} \\
(1.19)\end{array}$ \\
\hline 1 year & $\begin{array}{c}-5.16^{* *} \\
(1.84)\end{array}$ & $\begin{array}{c}-6.37 \\
(4.02)\end{array}$ & $\begin{array}{c}-4.89^{* *} \\
(2.02)\end{array}$ & $\begin{array}{c}-4.33 \\
(2.96)\end{array}$ & $\begin{array}{c}-2.07 \\
(2.20)\end{array}$ & $\begin{array}{c}-5.28 \\
(3.92)\end{array}$ & $\begin{array}{c}-5.02^{* *} \\
(1.52)\end{array}$ & $\begin{array}{c}-7.57 \\
(4.97)\end{array}$ & $\begin{array}{c}-4.79^{* * *} \\
(1.61)\end{array}$ \\
\hline 2 years & $\begin{array}{c}-3.18 \\
(2.29)\end{array}$ & $\begin{array}{c}-5.23 \\
(5.28)\end{array}$ & $\begin{array}{c}-2.68 \\
(2.46)\end{array}$ & $\begin{array}{c}-3.51 \\
(3.22)\end{array}$ & $\begin{array}{r}-0.68 \\
(3.35)\end{array}$ & $\begin{array}{c}-4.59 \\
(4.37)\end{array}$ & $\begin{array}{r}-3.46^{*} \\
(1.87)\end{array}$ & $\begin{array}{c}-6.01 \\
(6.44)\end{array}$ & $\begin{array}{r}-3.25^{*} \\
(1.92)\end{array}$ \\
\hline 3 years & $\begin{array}{c}-1.16 \\
(1.80)\end{array}$ & $\begin{array}{c}-3.94 \\
(3.85)\end{array}$ & $\begin{array}{c}-0.44 \\
(1.95)\end{array}$ & $\begin{array}{c}-2.37 \\
(3.06)\end{array}$ & $\begin{array}{c}-1.24 \\
(2.88)\end{array}$ & $\begin{array}{c}-2.35 \\
(3.77)\end{array}$ & $\begin{array}{c}-2.46 \\
(1.73)\end{array}$ & $\begin{array}{c}-4.49 \\
(4.52)\end{array}$ & $\begin{array}{c}-2.07 \\
(1.84)\end{array}$ \\
\hline First-stage $F$ & 25.8 & 33.0 & 18.4 & 8.4 & 48.7 & 5.3 & 29.5 & 25.8 & 21.6 \\
\hline Obs. & 2,099 & 621 & 1,478 & 1,492 & 573 & 919 & 2,408 & 629 & 1,779 \\
\hline \multicolumn{10}{|c|}{ Panel C: Consumption } \\
\hline On impact & $\begin{array}{c}3.69^{* *} \\
(1.44)\end{array}$ & $\begin{array}{c}-2.41 \\
(3.17)\end{array}$ & $\begin{array}{c}4.69^{* * *} \\
(1.65)\end{array}$ & $\begin{array}{c}4.61^{*} \\
(2.42)\end{array}$ & $\begin{array}{c}-4.98 \\
(3.48)\end{array}$ & $\begin{array}{c}6.63^{* *} \\
(3.23)\end{array}$ & $\begin{array}{c}2.99^{* * *} \\
(1.13)\end{array}$ & $\begin{array}{c}-2.73 \\
(3.73)\end{array}$ & $\begin{array}{c}3.62^{* * *} \\
(1.26)\end{array}$ \\
\hline 1 year & $\begin{array}{c}7.90^{* *} \\
(2.43)\end{array}$ & $\begin{array}{c}-1.21 \\
(1.91)\end{array}$ & $\begin{array}{c}9.97^{* *} \\
(3.06)\end{array}$ & $\begin{array}{r}7.17^{*} \\
(3.96)\end{array}$ & $\begin{array}{c}-1.76 \\
(4.10)\end{array}$ & $\begin{array}{r}9.21^{*} \\
(5.29)\end{array}$ & $\begin{array}{c}6.29^{* *} \\
(1.81)\end{array}$ & $\begin{array}{c}-0.81 \\
(2.50)\end{array}$ & $\begin{array}{c}7.19^{* * *} \\
(2.11)\end{array}$ \\
\hline 2 years & $\begin{array}{c}8.38^{* *} \\
(3.41)\end{array}$ & $\begin{array}{c}-0.57 \\
(2.65)\end{array}$ & $\begin{array}{l}10.68^{* *} \\
(4.42)\end{array}$ & $\begin{array}{c}9.95 \\
(6.41)\end{array}$ & $\begin{array}{r}-1.42 \\
(5.54)\end{array}$ & $\begin{array}{l}12.76 \\
(8.94)\end{array}$ & $\begin{array}{c}6.37^{* *} \\
(2.49)\end{array}$ & $\begin{array}{c}-0.30 \\
(3.22)\end{array}$ & $\begin{array}{c}7.23^{* *} \\
(2.87)\end{array}$ \\
\hline 3 years & $\begin{array}{r}7.52^{*} \\
(3.96)\end{array}$ & $\begin{array}{c}-3.21 \\
(4.54)\end{array}$ & $\begin{array}{c}9.92^{* *} \\
(4.95)\end{array}$ & $\begin{array}{c}8.94 \\
(7.59)\end{array}$ & $\begin{array}{c}-7.01 \\
(4.58)\end{array}$ & $\begin{array}{c}12.62 \\
(10.37)\end{array}$ & $\begin{array}{c}6.44^{* *} \\
(3.00)\end{array}$ & $\begin{array}{c}-2.36 \\
(5.12)\end{array}$ & $\begin{array}{c}7.21^{\text {** }} \\
(3.37)\end{array}$ \\
\hline First-stage $F$ & 24.6 & 21.0 & 18.0 & 7.7 & 20.3 & 5.1 & 30.6 & 16.8 & 23.2 \\
\hline Obs. & 2,118 & 636 & 1,482 & 1,510 & 579 & 931 & 2,447 & 644 & 1,803 \\
\hline
\end{tabular}

Notes: This table reports the response of the real exchange rate, current account-to-GDP ratio, and consumption to an expansionary $g$ shock of 1 percent of GDP. "Adv" denotes the advanced-countries sample, "Dev" denotes the developing-countries sample. The $g$ shocks are constructed using military spending as an instrument for total government spending. In the first three columns, we control for political risks rating in each country. In the next three columns, we add the nominal policy rate to control for the monetary policy stance. In the last three columns, we control for time fixed effects.

quantitatively similar to the baseline. ${ }^{28}$

\section{Comparison with Previous Literature}

We compare our results with those of Ilzetzki, Mendoza, and Végh (2013) and Kim (2015), two studies that examine relatively large panels of countries. Although Ilzetzki, Mendoza, and Végh (2013) focus primarily on the size of fiscal multipliers, their empirical strategy employs a VAR in four variables ( $g, y$, REER, and CA), which generates the response of the REER to government-

\footnotetext{
${ }^{28}$ We also estimate the effects of public investment on the REER, consumption, and the current account. The results are presented in Appendix Table C16. We note that since the number of observations with public investment is much smaller than that in the baseline with government consumption, many estimates are not significant.
} 
Table 6. REER response: Comparison with Ilzetzki, Mendoza, and Végh (2013) and Kim (2015)

\begin{tabular}{lcccc}
\hline \hline & \multicolumn{3}{c}{ IMV sample } & Kim sample \\
\cline { 2 - 5 } & All & Adv & Dev & All \\
& $(1)$ & $(2)$ & $(3)$ & -5.00 \\
\hline On impact & 2.65 & $-9.46^{*}$ & 6.52 & $(4.73)$ \\
& $(3.19)$ & $(5.39)$ & $(4.19)$ & -4.92 \\
1 year & -0.57 & $-13.79^{*}$ & 3.38 & $(7.58)$ \\
& $(4.43)$ & $(7.57)$ & $(5.67)$ & -14.66 \\
2 years & -6.97 & $-23.15^{*}$ & -2.08 & $(10.53)$ \\
& $(6.33)$ & $(11.88)$ & $(8.34)$ & -19.40 \\
3 years & -6.83 & $-30.48^{* *}$ & 1.24 & $(14.71)$ \\
& $(7.09)$ & $(14.98)$ & $(8.33)$ & 21.4 \\
First-stage $F$ & 17.0 & 4.4 & 9.8 & 278 \\
Obs. & 551 & 262 & 289 & \\
\hline
\end{tabular}

Notes: This table reports the response of the REER to an increase in the $g$ shock of 1 percent of GDP in the restricted samples of Ilzetzki, Mendoza, and Végh (2013) and Kim (2015). "Adv" denotes the advancedcountries sample, "Dev" denotes the developing-countries sample. The $g$ shocks are constructed using military spending as an instrument for total government spending.

spending shocks, reported in the paper as well. Their results are somewhat inconclusive due to wide confidence intervals, and-if anything — they support REER depreciation over long horizons. To make sure that the difference between our results and theirs is not due to country coverage, columns (1) to (3) in Table 6 report the estimates of the REER response for the case when our methodology is applied to the sample that matches theirs as closely as possible. ${ }^{29}$ We find that real exchange rates depreciate in advanced economies, consistent with both our baseline results and theirs. The difference is that our procedure applied to the developing-countries sample implies real exchange-rate appreciation at most horizons, although our estimates with the restricted sample have wide confidence bands.

We also estimate our baseline specification in the sample that matches the 18 countries analyzed in Kim (2015). ${ }^{30}$ Kim (2015) also identifies government-spending shocks using government consumption data with the Blanchard and Perotti (2002) strategy. He finds that real exchange rates depreciate and the current account improves over time. We report the estimated responses of real exchange rates using Kim's sample and our identification strategy in column (4) of Table 6. Consistent with his paper, we find that real exchange rates depreciate after a government spending shock. The main difference from Kim's paper is that, in our case, the current account deteriorates. ${ }^{31}$

To summarize, we find that our estimates using the restricted samples close to the two previous

\footnotetext{
${ }^{29}$ We match their sample fairly well. We have military spending data for all countries in their study, except Iceland. The only caveat is that our sample period for Australia, Canada, France, the United Kingdom, and the United States starts at 1989, while theirs goes back to the 1960s, except for France (1976). For the other 38 (out of 44) countries, we have the same coverage. We also exclude observations after 2008 to match their sample period.

${ }^{30}$ Kim's sample includes only advanced countries and is a subset of Ilzetzki, Mendoza, and Végh (2013) in the period from 1981 to 2010. We match his sample fairly well, again except for Australia, Canada, France, the United Kingdom, and the United States.

${ }^{31}$ We also estimate an SVAR-type regression by combining the Blanchard and Perotti (2002) identification strategy with local projections and applying this method to our data. Since the identification strategy based on time and decision lags does not have strong justification for annual data, we need to be careful interpreting the results, which are presented in Appendix Table C18.
} 
studies are consistent with some of their results. There remain some differences, which may be attributed to the sample composition or the identification approach. Yet, it is important to pool the information from many countries-as we do in this paper-since the confidence intervals are wide when we restrict the sample to be similar to the previous studies and since the confidence intervals in those papers are also wide.

\section{Empirical Facts vs. Theory}

Are the empirical facts documented earlier consistent with existing theories? What features can explain the differences between advanced and developing countries? In this section, we answer these questions by comparing the empirical findings with the predictions of a standard international business-cycle model. We then discuss potential explanations for the observed effects of government spending shocks in both advanced and developing countries.

\subsection{Challenges of A Standard International Business-Cycle Model}

A standard international business-cycle model - which has been widely used in the literature, starting at least from the real business cycle model of Backus, Kehoe, and Kydland (1992), and extended to the model with nominal rigidities in Chari, Kehoe, and McGrattan (2002), Galí and Monacelli (2005), and Steinsson (2008), among others-features two countries, Home (H) and Foreign (F), and two goods, with each country specializing in one of the goods. Consumer preferences have a home bias. The asset markets are complete. ${ }^{32}$ Since the model setup is well known, the details are relegated to Appendix D.

Comparing the model predictions with the empirical facts, we find that the predictions about the current-account responses are consistent with the data. However, the main discrepancies between the standard model and the data lie in the real exchange rate depreciation in advanced countries, consumption increase in developing countries, and the consumption-real exchange-rate relationship (the risk-sharing condition) in both advanced and developing countries.

First, the standard model does not generate real depreciation, observed in advanced countries, and an increase in consumption, observed in developing countries. In theory, in response to a government-spending shock, the real exchange rate appreciates. The intuition is that, with a home bias, government consumption increases demand for domestic goods, causing the price of domestic goods to increase relative to the price of foreign goods, so the real exchange rate appreciates. This prediction is in line with the real exchange-rate responses in developing countries, but not in advanced countries. The real depreciation in advanced countries is dubbed the "real exchange-rate puzzle," documented, among others, in Monacelli and Perotti (2010) and Ravn, Schmitt-Grohé, and Uribe (2012) in four advanced countries. Furthermore, in the standard model, a government

\footnotetext{
${ }^{32}$ The analyses in this section do not depend on the pricing assumption (Calvo sticky prices vs. flexible prices) if the asset markets are complete.
} 
spending shock implies an increase in taxes, and causes consumption to fall. This prediction about consumption response is consistent with that in advanced countries, but not in developing countries.

Second, the decline in the current account-to-output ratio in the data for both advanced and developing countries is consistent with the prediction of the standard model. In the model, a positive government-spending shock lowers the net exports-to-output ratio. Intuitively, the strong wealth effects of government spending lead to a decline in consumption and appreciation of the real exchange rate. As the real exchange rate appreciates, households substitute home goods for foreign goods; thus, imports can go up. At the same time, there are less imports because consumption falls. Therefore, in principle, net exports can go up or down. Under the baseline calibration consistent with the literature, the net exports-to-output ratio falls, which is in line with the empirical evidence in both groups of countries.

Third, conditional on a government-spending shock, the risk-sharing condition holds neither for advanced nor for developing countries. In the model, the risk-sharing condition implies a negative relationship between consumption and the real exchange rate: the real exchange rate appreciates and consumption declines. To see this, with complete asset markets, the model implies that,

$$
\frac{U_{c}^{H}}{U_{c}^{F}}=q,
$$

where $U_{c}^{i}$ with $i=\{H, F\}$ denotes the marginal utility of consumption in the Home and Foreign country, respectively, and $q$ is the real exchange rate, with an increase in $q$ representing real appreciation. Under a standard, separable utility function, this risk-sharing condition can be written as,

$$
\frac{C^{-\sigma}}{\left(C^{*}\right)^{-\sigma}}=q,
$$

where $C$ and $C^{*}$ denote consumption in the Home and Foreign country, respectively, and $\sigma$ is the inverse intertemporal elasticity of substitution. This condition implies that if domestic consumption relative to foreign consumption falls, the real exchange rate appreciates, and the reverse is true if consumption increases. In the standard model, a positive government spending shock leads to a decline in consumption. Therefore, the risk-sharing condition implies that the real exchange rate has to appreciate. This prediction of the standard model is not consistent with consumption-real exchange rate responses in either advanced or developing countries. In other words, we find a risk-sharing puzzle, conditional on a government-spending shock. The international business cycle literature, such as Backus and Smith (1993) and Kollmann (1995), documented the violation of the risk-sharing condition for the unconditional correlation of consumption and the real exchange rate. Recent papers, such as Corsetti, Dedola, and Viani (2012), document the violation of this relationship conditional on productivity shocks. However, papers such as Monacelli and Perotti (2010) and Ravn, Schmitt-Grohé, and Uribe (2012) find the consumption-real exchange rate relationship conditional on government spending shocks consistent with this risk-sharing condition. In contrast, our empirical evidence suggests that this conditional relationship does not hold. 
The above analyses imply that as long as the model gives rise to the risk-sharing condition of Equation (4), it cannot be reconciled with the empirical evidence. For example, Ravn, SchmittGrohé, and Uribe (2012) augment standard models with deep habits to generate real exchange-rate depreciation consistent with empirical responses in advanced countries. However, their mechanism does not explain all the empirical findings in either advanced countries or developing countries, because it produces a real exchange-rate-consumption relationship similar to Equation (4). In other words, when the real exchange rate depreciates in that model, consumption increases, whereas the point estimates of the consumption responses are negative in the data for advanced countries. Overall, our empirical evidence does not lend support to standard open-economy models with complete asset markets.

\subsection{What Can Explain the Dynamics in Advanced and Developing Countries?}

Although the risk-sharing condition is violated in both advanced and developing countries, the inconsistency of advanced-countries dynamics with those in the standard model is due to the depreciation of the real exchange rate, while it is due to the consumption response for developing countries. In this section, we discuss the extensions of the standard model that can reconcile the model with the empirical findings in both groups of countries. Specifically, real depreciation in advanced countries can be generated by a model with incomplete markets in the form of a one-period noncontingent bond. To explain the responses in developing countries, the model needs either complementarity of consumption and hours or a strong form of financial frictions such as the presence of rule-of-thumb consumers, or both.

\subsubsection{Advanced countries: Incomplete Asset Markets}

In a model with incomplete asset markets, agents can trade only a one-period noncontingent bond. The incomplete markets model has been used extensively in the small open economy literature. The risk-sharing condition in Equation (3) holds only in expectation. ${ }^{33}$ Details of the model and the risk-sharing equation for the incomplete markets model are given in Section D.2 in the appendix. Trading bonds helps agents to ensure that relative growth in the marginal utility of consumption in the domestic economy is, in expectation, associated with real appreciation. Nevertheless, the noncontingent bond does not insure agents against country-specific shocks ex ante.

While the responses of the incomplete markets model can be similar to those of the standard model when the stochastic process is transitory, a close to random walk process in the incomplete markets model can generate substantially different dynamics compared to the standard model. ${ }^{34}$ In-

\footnotetext{
${ }^{33}$ There is an additional term accounting for the movements in the endogenous discount factor, which is formulated in the model with incomplete markets for a locally stable, unique equilibrium. The parameter governing the movements of the endogenous discount factor is often set to be small only to induce stationarity; thus, the effect of the movements in the endogenous discount factor on the risk-sharing condition is negligible. In the small open economy literature, this parameter is sometimes associated with the degree of financial frictions that a country faces. See, for example, Garcia-Cicco, Pancrazi, and Uribe (2010).

${ }^{34}$ Previous papers found almost no difference between incomplete and complete market models if the technology shock is transitory. See, for example, Baxter and Crucini (1995).
} 
tuitively, a persistent (close to permanent) government spending shock, as observed in the data, can have large wealth effects, causing depreciation-instead of appreciation, as in complete marketsof the real exchange rate. For example, Corsetti, Dedola, and Leduc (2008) suggest that with a low elasticity of substitution between home and foreign goods, consumption falls and the real exchange rate depreciates after a (negative) technology shock. In the appendix, we calibrate the incomplete markets model with a low elasticity of substitution between home and foreign goods, and find that it can generate a decline in consumption and real depreciation in response to a government spending shock, consistent with the observed effects of government spending shocks in advanced countries.

\subsubsection{Developing Countries: Consumption-Hours Complementarity and Rule-of-Thumb Con- sumers}

Since the model with incomplete asset markets does not generate a positive consumption response, other frictions are necessary to reconcile the model's predictions with the responses in developing countries. We now discuss two channels: consumption-hours complementarity and the presence of rule-of-thumb consumers.

Consumption-hours complementarity means that the marginal utility of consumption increases when households move from non-work to work, or work more hours. In the model with consumptionhours complementarity, we can parameterize a higher degree of complementarity to reflect a larger size of the home production sector or a higher substitutability of market and home goods in developing countries, where home production is a prevalent phenomenon. Besides, the special role played by the agricultural sector and small businesses in these countries can lead to higher substitutability between home and market goods: when the market wage increases, households switch to market labor and consumption. Therefore, consumption-hours can be more complementary in developing countries than in advanced countries. ${ }^{35}$

Bilbiie (2011) analyzes how the complementarity between consumption and hours can lead to an increase in consumption after government spending shocks in a closed economy setting. The intuition that consumption-hours complementarity can increase consumption is as follows. Government spending shocks generate an increase in labor supply due to wealth effects; consumption can increase when hours and consumption are complements. Even though wealth effects tend to lower consumption, as long as the complementarity is strong enough, consumption can increase in equilibrium. Therefore, for a given degree of complementarity, consumption can increase more with smaller wealth effects. Similarly, the more transitory the government spending shock is, the smaller wealth effects are, and so consumption can increase more. Other factors, such as the degree of price rigidities and monetary policy, can also be important for the increase of consumption after a government spending shock. With stickier prices or with more accommodative monetary policy, government spending shocks create additional demand, thereby increasing labor and, consequently,

\footnotetext{
${ }^{35}$ Gnocchi, Hauser, and Pappa (2016) show that the dynamics of a model with consumption-hours complementarity can replicate those of a model with home production. Additionally, a higher degree of complementarity corresponds to a higher degree of substitutability of market and home goods or to a larger home-production sector.
} 
consumption. $^{36}$

Furthermore, under consumption-hours complementarity, the risk-sharing condition states that the responses of the real exchange rate depend on the responses of consumption, hours worked, and the degree of complementarity. For a given response of consumption-since hours increasea higher degree of complementarity leads to an increase in the marginal utility of consumption. Thus, the real exchange rate can appreciate even when consumption increases. In the appendix, we demonstrate that a calibrated model with consumption-hours complementarity under either complete or incomplete markets can generate simultaneously real exchange rate appreciation and an increase in consumption, consistent with the empirical responses for developing countries.

Besides consumption-hours complementarity, the presence of rule-of-thumb consumers can also explain the empirical findings for developing countries. Our motivation to investigate this feature is that more consumers are financially constrained in developing countries than in advanced countries. In the model, a fraction of households are rule-of-thumb consumers, also called hand-to-mouth consumers. They have no access to financial markets. This formulation of the rule-of-thumb consumers with no bond trading can be interpreted as a form of financial frictions, which is stronger than the incomplete market assumption with one-period noncontingent bond trading discussed above. The mechanism of this feature in the model works as follows: An increase in government consumption leads to an increase in labor supply, as in the standard model. With an increase in labor income, consumption of the rule-of-thumb consumers increases, whereas consumption of the forward-looking households declines, due to negative wealth effects. If the fraction of rule-of-thumb consumers is sufficiently high, aggregate consumption will increase. ${ }^{37}$ The real exchange rate is determined by the risk-sharing condition that holds for the forward-looking households with access to international financial markets. Therefore, the real exchange rate appreciates, as in the standard model. Overall, the predictions of the model with rule-of-thumb consumers can also be consistent with the empirical facts for developing countries.

The discussion above suggests that while incomplete markets with a one-period noncontingent bond may be sufficient to characterize the responses of advanced economies to government spending shocks, consumption-hours complementarity and a strong form of financial frictions, such as the one with some agents having no access to financial markets, are necessary to explain developing countries. In other words, we can explain the different responses to government spending shocks in advanced and developing countries by parameterizing different degrees of these frictions within the same model. ${ }^{38}$

\footnotetext{
${ }^{36}$ See Bilbiie (2011) for a detailed discussion of the role of price rigidities in generating a positive consumption response to a government spending shock in the context of a closed economy model.

${ }^{37}$ Galí, López-Salido, and Vallés (2007) introduce these agents in a closed economy setting to induce an increase in consumption after a government spending shock.

${ }^{38}$ We demonstrate this point by calibrating the model in the appendix.
} 


\section{Concluding Remarks}

The effects of government spending in an open-economy environment are still little understood. The workhorse open-economy models fail to match basic empirical regularities, giving rise to prominent "puzzles" in the international economics literature. These empirical regularities, in turn, are based on data from only a few, mostly advanced, economies. With a unique data set covering a large number of countries, we contribute to a better understanding of the fiscal policy effects, not only in advanced, but also in developing countries. We provide external validity for the puzzle that real exchange rates depreciate in response to an expansionary government-spending shock in advanced countries; and provide new evidence for the conditional violation of the risk-sharing condition in response to government-spending shocks. We also investigate the role of development, exchangerate regimes, and trade openness in the international transmission mechanism of fiscal policy.

We document new facts and reach a key conclusion: significant variation in specific economic conditions and institutional environments across countries leads to very different responses to fiscal shocks of exchange rates, consumption, and current accounts. Therefore, one cannot easily extend evidence from the United States or OECD countries to less-developed economies. Specifically, we emphasize that although some regularities, such as the consumption-exchange-rate puzzle and the decline in current accounts conditional on government-spending shocks, hold uniformly across groups of countries, other puzzles hold only in developed countries (real depreciation). These data regularities are most pronounced under a flexible exchange-rate regime. Furthermore, there is considerable heterogeneity across advanced and developing countries.

We discuss potential explanations for the differences between advanced and developing countries. The explanation of why the responses in advanced countries are different from those in developing countries is probably a combination of the following factors: financial frictions-such as market incompleteness or households with credit constraints-home production, and the monetary policy stance, among others. The quantitative evaluation of these different channels requires more information. In this paper, we have presented strong evidence rejecting the standard international business-cycle model and the risk-sharing condition it produces, commonly assumed in the open-economy literature.

Our results call for more research on the role of country-specific institutional arrangements in the transmission and propagation of fiscal shocks, and for more use of macro data from developing countries. We also encourage more diversity in data sources used to estimate the effect of fiscal policy on macroeconomic variables.

\section{References}

Abbas, S. M. Ali, Nazim Belhocine, Asmaa A. ElGanainy, and Mark A. Horton. 2010. "A Historical Public Debt Database." IMF Working Paper 10/245.

Auerbach, Alan J., and Yuriy Gorodnichenko. 2012. "Measuring the Output Responses to Fiscal Policy." American Economic Journal: Economic Policy 4(2): 1-27. 
_ 2016. "Effects of Fiscal Shocks in a Globalized World." IMF Economic Review 64(1): 177-215.

Backus, David K., Patrick J. Kehoe, and Finn E. Kydland. 1992. "International Real Business Cycles.” Journal of Political Economy 100(4): 745-775.

Backus, David K., and Gregor W. Smith. 1993. "Consumption and Real Exchange Rates in Dynamic Economies with Non-Traded Goods." Journal of International Economics 35(3-4): 297-316.

Barro, Robert J., and Charles J. Redlick. 2011. "Macroeconomic Effects from Government Purchases and Taxes." Quarterly Journal of Economics 126(1): 51-102.

Baxter, Marianne, and Mario Crucini. 1995. "Business Cycles and the Asset Structure of Foreign Trade." International Economic Review 36(4): 821-854.

Bazzi, Samuel, and Christopher Blattman. 2014. "Economic Shocks and Conflict: Evidence from Commodity Prices." American Economic Journal: Macroeconomics 6(4): 1-38.

Bilbiie, Florin O. 2011. "Non-Separable Preferences, Frisch Labor Supply and the Consumption Multiplier of Government Spending: One Solution to a Fiscal Policy Puzzle." Journal of Money, Credit and Banking 43(1): 221-251.

Blanchard, Olivier, and Roberto Perotti. 2002. "An Empirical Characterization of the Dynamic Effects of Changes in Government Spending and Taxes on Output." Quarterly Journal of Economics 117(4): 13291368.

Bodenstein, Martin. 2011. "Closing Large Open Economy Models." Journal of International Economics 84(2): 160-177.

Chari, V. V., Patrick J. Kehoe, and Ellen R. McGrattan. 2002. "Can Sticky Price Models Generate Volatile and Persistent Real Exchange Rates?" Review of Economic Studies 69(3): 533-563.

Collier, Paul. 2006. "War and Military Expenditure in Developing Countries and Their Consequences for Development." Economics of Peace and Security Journal 1(1): 10-13.

Conley, Timothy G., Christian B. Hansen, and Peter E. Rossi. 2012. "Plausibly Exogenous." Review of Economics and Statistics 94(1): 260-272.

Corsetti, Giancarlo, Luca Dedola, and Sylvain Leduc. 2008. "International Risk Sharing and the Transmission of Productivity Shocks." Review of Economic Studies 75(2): 443-473.

Corsetti, Giancarlo, Luca Dedola, and Francesca Viani. 2012. "Traded and Nontraded Goods Prices, and International Risk Sharing: An Empirical Investigation." In NBER International Seminar on Macroeconomics 2011, vol. 8, edited by Jeffrey A. Frankel and Christopher A. Pissarides, chap. 8. University of Chicago Press, 403-466.

Corsetti, Giancarlo, André Meier, and Gernot J. Müller. 2012. "Fiscal Stimulus with Spending Reversals." Review of Economics and Statistics 94(4): 878-895.

Corsetti, Giancarlo, and Gernot J. Müller. 2006. "Twin Deficits: Squaring Theory, Evidence and Common Sense." Economic Policy 21(48): 597-638.

Darvas, Zsolt. 2012. "Real Effective Exchange Rates for 178 Countries: A New Database." Bruegel Working Paper 716.

Enders, Zeno, Gernot J. Müller, and Almuth Scholl. 2011. "How Do Fiscal and Technology Shocks Affect Real Exchange Rates? New Evidence for the United States." Journal of International Economics 83(1): 53-69.

Galí, Jordi, J. David López-Salido, and Javier Vallés. 2007. "Understanding the Effects of Government Spending on Consumption." Journal of the European Economic Association. 1(1): 227-270. 
Galí, Jordi, and Tommaso Monacelli. 2005. "Monetary Policy and Exchange Rate Volatility in a Small Open Economy." Review of Economic Studies 72(3): 707-734.

Garcia-Cicco, Javier, Roberto Pancrazi, and Martin Uribe. 2010. "Real Business Cycles in Emerging Countries?" American Economic Review 100(5): 2510-2531.

Gleditsch, Nils Petter, Peter Wallensteen, Mikael Eriksson, Margareta Sollenberg, and Håvard Strand. 2002. "Armed Conflict 1946-2001: A New Dataset." Journal of Peace Research 39(5): 615-637.

Gnocchi, Stefano, Daniela Hauser, and Evi Pappa. 2016. "Housework and Fiscal Expansions." Journal of Monetary Economics 79: 94-108.

Hall, Robert E. 2009. "By How Much Does GDP Rise If the Government Buys More Output?” Brookings Papers on Economic Activity 40(2): 183-249.

Ilzetzki, Ethan O., Enrique G. Mendoza, and Carlos A. Végh. 2013. "How Big (Small?) Are Fiscal Multipliers?" Journal of Monetary Economics 60(2): 239-254.

Ilzetzki, Ethan O., Carmen M. Reinhart, and Kenneth Rogoff. 2009. "Exchange Rate Arrangements into the 21st Century: Will the Anchor Currency Hold?" Unpublished.

Dataset available at http://scholar.harvard.edu/rogoff/publications/exchange-Rate-Arrangements-21StCentury-Will-Anchor-Currency-Hold.

Jordà, Òscar. 2005. "Estimation and Inference of Impulse Responses by Local Projections." American Economic Review 95(1): 161-182.

Kim, Soyoung. 2015. "Country Characteristics and the Effects of Government Consumption Shocks on the Current Account and Real Exchange Rate." Journal of International Economics 97(2): 436-447.

Kim, Soyoung, and Nouriel Roubini. 2008. "Twin Deficit or Twin Divergence? Fiscal Policy, Current Account, and Real Exchange Rate in the U.S.” Journal of International Economics 74(2): 362-383.

Klein, Michael W., and Jay C. Shambaugh. 2008. "The Dynamics of Exchange Rate Regimes: Fixes, Floats, and Flips." Journal of International Economics 75(1): 70-92.

Kollmann, Robert. 1995. "Consumption, Real Exchange Rates and the Structure of International Asset Markets." Journal of International Money and Finance 14(2): 191-211.

Kraay, Aart. 2012. "How Large Is the Government Spending Multiplier? Evidence from World Bank Lending." Quarterly Journal of Economics 127(2): 829-887.

Levy-Yeyati, Eduardo, and Federico Sturzenegger. 2005. "Classifying Exchange Rate Regimes: Deeds vs. Words." European Economic Review 49(6): 1603-1635.

Miyamoto, Wataru, Thuy Lan Nguyen, and Dmitriy Sergeyev. 2016. "Government Spending Multiplier under the Zero Lower Bound: Evidence from Japan.” Working paper.

Monacelli, Tommaso, and Roberto Perotti. 2010. "Fiscal Policy, the Real Exchange Rate and Traded Goods." Economic Journal 120(544): 437-461.

Pescatori, Andrea, Damiano Sandri, and John Simon. 2014. "Debt and Growth: Is There a Magic Threshold?" IMF Working Paper 14/34.

Pettersson, Therése, and Peter Wallensteen. 2015. "Armed Conflict, 1946-2014." Journal of Peace Research 52(4): 536-550.

Ramey, Valerie A. 2011. "Identifying Government Spending Shocks: It's All in the Timing." Quarterly Journal of Economics 126(1): 1-50. 
Ramey, Valerie A., and Sarah Zubairy. 2014. "Government Spending Multipliers in Good Times and in Bad: Evidence from U.S. Historical Data." Journal of Political Economy. Forthcoming.

Ravn, Morten O., Stephanie Schmitt-Grohé, and Martín Uribe. 2012. "Consumption, Government Spending, and the Real Exchange Rate." Journal of Monetary Economics 59(3): 215-234.

Reinhart, Carmen M., and Kenneth S. Rogoff. 2011. "From Financial Crash to Debt Crisis." American Economic Review 101(5): 1676-1706. Data available at http://www.carmenreinhart.com/data/browse-bytopic/topics/7/.

Shambaugh, Jay C. 2004. "The Effect of Fixed Exchange Rates on Monetary Policy." Quarterly Journal of Economics 119(1): 300-351.

Sheremirov, Viacheslav, and Sandra Spirovska. 2015. "Output Response to Government Spending: Evidence from New International Military Spending Data." Federal Reserve Bank of Boston Working Paper 15-9.

Steinsson, Jón. 2008. "The Dynamic Behavior of the Real Exchange Rate in Sticky-Price Model." American Economic Review 98(1): 519-533.

Uzawa, Hirofumi. 1968. "Time Preference, the Consumption Function and Optimum Asset Holdings." In Value, Capital and Growth: Papers In Honor of Sir John Hicks, edited by James N. Wolfe. Edinburgh University Press, 485-504. 


\section{Appendix}

\section{A Data}

Annual data on military spending are available for 160 countries during 1989-2013, with 3,312 total observations. We use the number of years for which these data are available to proxy for the reliability of the data for a particular country. For this reason, we exclude 29 countries that have fewer than 15 observations for changes in military spending. ${ }^{1}$ We also exclude Kuwait, as the country exhibited unusually large swings in military spending growth rates during and after the Gulf War. Our inclusion criteria also weed out countries that had significant wars (both in terms of severity and duration) on domestic soil, such as Afghanistan, Iraq, and Sudan, leaving us with a sample of relatively stable countries without drastic fluctuations in economic activity and military spending. For similar reasons, we also drop Angola, Pakistan, Rwanda, and Sri Lanka. The final sample contains 125 countries (29 advanced countries and 96 developing ones according to the World Bank 2000 classification) and 2,766 observations in total. Table A1 contains information on the countries available in the entire sample, as well as the number of observations available per country for our variables. The following is a detailed summary of the data used in our analysis and the relevant sources.

Table A1. Data Sources and Coverage

\begin{tabular}{|c|c|c|c|c|c|}
\hline & \multicolumn{3}{|c|}{ Number of countries } & \multirow[b]{2}{*}{$\begin{array}{c}\text { Sample } \\
\text { period } \\
\text { (4) }\end{array}$} & \multirow[b]{2}{*}{$\begin{array}{l}\text { Source } \\
\text { (5) }\end{array}$} \\
\hline & $\begin{array}{c}\text { Entire } \\
\text { sample } \\
(1)\end{array}$ & $\begin{array}{l}\text { Advanced } \\
\text { countries } \\
\text { (2) }\end{array}$ & $\begin{array}{c}\text { Developing } \\
\text { countries } \\
\text { (3) }\end{array}$ & & \\
\hline Total government spending & 125 & 29 & 96 & 1989-2013 & National Accounts Main Aggregates Database (UN) \\
\hline Private consumption & 125 & 29 & 96 & 1989-2013 & NAMAD \\
\hline Real GDP & 125 & 29 & 96 & 1989-2013 & NAMAD \\
\hline Real exchange rate (1) & 125 & 29 & 96 & 1992-2013 & Bruegel \\
\hline Current account & 125 & 29 & 96 & 1989-2013 & WEO \\
\hline Trade balance & 125 & 29 & 96 & 1989-2013 & World Development Indicators (World Bank) \\
\hline Unemployment rate & 123 & 29 & 94 & 1991-2013 & WDI \\
\hline Government debt & 125 & 29 & 96 & 1989-2012 & Historical Public Debt (IMF) \\
\hline Wars & 125 & 29 & 96 & 1989-2013 & UCDP/PRIO version 4 (2015) \\
\hline Tax rates $(1)$ & 33 & 24 & 9 & 1989-2013 & OECD \\
\hline Commodity exports (1) & 124 & 29 & 95 & 1995-2013 & UN Conference on Trade and Development (UNCTAD) \\
\hline Commodity exports (2) & 124 & 29 & 95 & 2000-2013 & Comtrade (UN) \\
\hline Military imports & 124 & 29 & 95 & 2002-2012 & World Military Expenditures and Arms Transfers (DoS) \\
\hline Financial crises & 125 & 29 & 96 & 1989-2013 & Reinhart and Rogoff (2011) \\
\hline International aid & 21 & 0 & 21 & 1989-2009 & 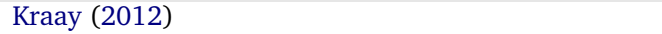 \\
\hline
\end{tabular}

Notes: Note that Klein and Shambaugh's (2008) classification is updated up to 2013.

Military Spending Stockholm International Peace Research Institute (SIPRI) reports data on total military expenditure at constant 2011 prices in U.S. dollars for 171 countries in 1988-2013. We calculate total military spending by using SIPRI's military spending-to-GDP ratio, which is available for 164 countries in the same period. More specifically, in order to compute a total military spending series at constant 2005 prices in national currency units, we multiply this ratio by real GDP obtained from the UN. SIPRI calculates the ratio of military spending to GDP in domestic currency at current prices for calendar years, where nominal GDP in

\footnotetext{
${ }^{1}$ The excluded countries are Afghanistan, Benin, Bosnia and Herzegovina, Central African Republic, Congo, Democratic Republic of Congo, Equatorial Guinea, Eritrea, Gabon, Gambia, Guinea, Guinea-Bissau, Haiti, Honduras, Iceland, Iraq, Liberia, Libya, Montenegro, Niger, Panama, Qatar, Tajikistan, Timor-Leste, Togo, Trinidad and Tobago, Turkmenistan, Uzbekistan, and Zimbabwe.
} 
national currency is collected from the IMF World Economic Outlook (WEO). ${ }^{2}$

Total Government Spending, Private Consumption, and Real GDP We obtain annual data on general government final consumption expenditure, household consumption expenditure, and real GDP at constant 2005 prices in national currency units from the UN's National Accounts Main Aggregates Database (NAMAD). ${ }^{3}$ The dataset contains time-series from 1970 onward for over 200 economies, which report to the UN's Statistics Division in the form of the National Accounts Questionnaires. ${ }^{4}$ We use the April 2015 version of the dataset, which has data available until 2013. The NAMAD consumption series additionally includes the consumption expenditures of nonprofit institutions serving households.

Real Effective Exchange Rates We obtain a bulk of our annual trade-weighted data on the real effective exchange rate (REER) from Bruegel, an independent economic think-tank that conducts research on a variety of global and European macroeconomic policy issues. Bruegel uses a weighting matrix to derive their CPIbased REERs, with 2007 as the base year. They collect their data primarily from the databases of international organizations: namely, the World Bank's World Development Indicators (WDI) and Global Economic Monitor databases, and the IMF's WEO database. They further supplement their data with official data from national governments, statistics offices, and central banks. ${ }^{5}$ Their dataset is uniquely comprehensive, including annual data for 172 countries from 1992 to 2014 (178 countries for monthly observations), with more coverage than any publicly available database. ${ }^{6}$ Due to our inclusion restrictions mentioned earlier, we utilize their annual dataset for 125 countries, for which a relatively long series of military spending is available. We use the January 2015 version of the dataset, which has data available until 2014.

Since Bruegel's series begins in 1992, we are left with the three-year period 1989-1991 for which we have data on total government and military spending, but not on REERs, resulting in a loss of almost 300 observations. To fill in this gap, we use CPI-based REERs from the IMF's International Financial Statistics (IFS) database. These exchange rates are period averages, with 2010 as the base year, for 96 countries between 1979 and 2014. After applying our inclusion criteria, we have the IFS REER data for 75 countries (26 advanced and 49 developing) during the 1989-2013 period. We splice the percentage changes in the Bruegel REER data with the percentage changes in the IFS REER series in all instances between 1989 and 1991 for which Bruegel data are missing. (The correlation coefficient between the changes in the series in our preferred sample is 0.9.) This allows us to regain 184 observations from over 60 countries. Thus, in our dataset, we have consistent REER data for 125 countries from 1989 to 2013.

Inflation The IMF's WEO database provides annual CPI data for 189 countries, beginning 1980. The WEO data present their annual inflation series in different ways, depending on two criteria: (1) using end-of-period values versus period averages; and (2) using percentage changes versus price indices. We use the periodaverage index for 125 countries during the 1989-2013 period. Methodologies and sources tend to differ across countries, as detailed in the national accounts notes. ${ }^{7}$ We use the October 2015 database, which has data available until 2013, usually with estimates of the values for subsequent years.

Current Account We use current account data, as a percentage of GDP, at an annual frequency, from the IMF's WEO database. The dataset covers 189 countries from 1980 to 2015, while our sample retains data for 125 countries between 1989 and 2013. The IMF aggregates these data from national ministries, offices, and the IMF's Staff Estimates, and, again, there is cross-country variation in methodologies. Similar to the inflation series, we use the October 2015 database.

\footnotetext{
${ }^{2}$ See http://www.sipri.org/research/armaments/milex/milex_database/copy_of_sources_methods and Table 1, footnote a) at http://books.sipri.org/files/FS/SIPRIFS1404.pdf.

${ }^{3}$ See http://unstats.un.org/unsd/nationalaccount/.

${ }^{4}$ For additional information and detailed methodology, see http://unstats . un.org/unsd/snaama/methodology .pdf.

${ }^{5}$ For detailed methodology and sources, see Darvas (2012).

${ }^{6}$ Darvas (2012) discusses a previous vintage of the dataset, which included data only until 2011.

${ }^{7}$ For more information, see the country-specific national accounts notes located at http://www.imf .org/external/pubs/ft/ weo/2015/02/weodata/co.pdf.
} 
Trade Balance We compute countries' trade balances using data on exports and imports of goods and services as a percentage of GDP from the World Bank's WDI database. We use the October 2015 version of the database, which has annual data for 195 countries and territories from 1960 to 2014. The exports and imports series are collected from the World Bank and the OECD national accounts data. These series exclude compensation of employees, investment income, and transfer payments. ${ }^{8}$ The WDI database provides a trade-balance series as well, called "Net trade in goods and services," which we do not use, because it is expressed in current U.S. dollars, thereby reflecting fluctuations in the exchange rate. Computing the trade balance as a percentage of GDP allows us to measure the trade balance at constant 2005 prices in national currency units. Overall, our dataset contains trade-balance data for 125 countries in the period 1989-2013.

Unemployment Rate We obtain unemployment rate data from the World Bank's WDI database. The World Bank collects the unemployment series from the International Labor Organization. ${ }^{9}$ Annual unemployment rates are available for 174 countries from 1991 to 2013. Our final sample contains labor data for 123 countries (29 advanced and 94 developing) during the 1991-2013 period. ${ }^{10}$ We use the October 2015 edition of the database.

Government Debt The IMF's Fiscal Affairs Department compiled a comprehensive database (Historical Public $D e b t$ ), with data for 178 countries (as well as certain groups, such as Emerging Markets, G-20, and so on) from 1875 to $2012 .{ }^{11}$ The data are available at an annual frequency, and gross government debt is reported as a median percentage of GDP. The IMF constructs their dataset using a variety of sources, including statistical handbooks, official government publications, and other databases compiled by researchers and independent organizations. An earlier version of the data was used in an IMF working paper expanding upon work in Chapter 3 of the October 2012 edition of the IMF WEO. ${ }^{12}$ In our sample, we have debt-to-GDP ratios for 125 countries from 1989 to 2012. This dataset is an extended version of the historical debt data used in Pescatori, Sandri, and Simon (2014).

Wars, Taxes, Interest Rates, Exchange Rate Regimes Data on wars, marginal tax rates, interest rates, and exchange-rate regime classifications are as follows. The data on wars are from the Correlates of War (COW) project. The dataset contains information on participating countries, start and end dates, and the number of battle deaths for each conflict, up to 2007. Annual marginal tax rates are taken from the OECD Central Government Personal Income Tax Rates and Thresholds dataset for 33 OECD countries in the period 1981-2014. We choose the top marginal income tax rate as our preferred measure. We further augment this measure with marginal income tax rates provided by KPMG, a Big Four auditor, for both advanced and developing countries during 2006-2014. End-of-period policy rates and discount rates are collected from Haver Analytics and the IMF's IFS database. Exchange-rate regime classifications are based on the IMF, Shambaugh (2004), Levy-Yeyati and Sturzenegger (2005), Klein and Shambaugh (2008), and Ilzetzki, Reinhart, and Rogoff (2009). In our analysis, we use the Klein and Shambaugh (2008) classification as the baseline.

Other Control Variables We also explore robustness of our results to the degree of political risk, commodity exports, military imports, financial crises, and international aid. The data sources for these control variables are summarized in Table A1.

\footnotetext{
${ }^{8}$ For details on methodology and for country-specific notes for the exports series, see http://databank.worldbank.org/ $\mathrm{data} /$ reports. aspx?source=2\&type=metadata\&series=NE.EXP.GNFS.ZS. For the imports series, see http://databank. worldbank .org/data/reports . aspx? source=2\&type=metadata\&series=NE. IMP . GNFS . ZS.

${ }^{9}$ For details on methodology and for country-specific notes, see the metadata for the series.

${ }^{10}$ The countries for which World Bank labor data are unavailable are Djibouti and the Seychelles.

${ }^{11}$ For many advanced countries, the series starts around this date, while the data for the United Kingdom goes back to the late 17th century. For the majority of countries, however, the data start at 1970 or later.

${ }^{12}$ For detailed methodology for the first version of the data (Abbas et al. 2010); and for the more recent IMF working paper, see Pescatori, Sandri, and Simon (2014).
} 


\section{B Baseline Sample}

\begin{tabular}{|c|c|c|c|c|}
\hline Country name & Sample period & Development & ER regime & Trade \\
\hline Albania & 1993-2013 & Developing & Flexible & Open \\
\hline Algeria & 1989-2013 & Developing & Flexible & Closed \\
\hline Argentina & 1989-2013 & Developing & Flexible & Closed \\
\hline Armenia & 1993-2013 & Developing & Flexible & Open \\
\hline Australia & 1989-2013 & Advanced & Flexible & Closed \\
\hline Austria & 1989-2013 & Advanced & Fixed & Open \\
\hline Azerbaijan & 1993-2013 & Developing & Flexible & Open \\
\hline Bahrain & 1989-2013 & Developing & Fixed & Open \\
\hline Bangladesh & 1989-2013 & Developing & Fixed & Closed \\
\hline Belarus & 1993-2013 & Developing & Flexible & Open \\
\hline Belgium & 1989-2013 & Advanced & Fixed & Open \\
\hline Belize & 1989-2013 & Developing & Fixed & Open \\
\hline Bolivia & 1990-2013 & Developing & Flexible & Closed \\
\hline Botswana & 1989-2013 & Developing & Flexible & Open \\
\hline Brazil & 1989-2013 & Developing & Flexible & Closed \\
\hline Brunei & 1989-2013 & Advanced & Fixed & Open \\
\hline Bulgaria & 1990-2013 & Developing & Fixed & Open \\
\hline Burkina Faso & 1989-2013 & Developing & Fixed & Closed \\
\hline Burundi & 1989-2013 & Developing & Flexible & Closed \\
\hline Cambodia & 1989-2013 & Developing & NA & Open \\
\hline Cameroon & 1989-2013 & Developing & Fixed & Closed \\
\hline Canada & 1989-2013 & Advanced & Flexible & Open \\
\hline Cape Verde & 1993-2011 & Developing & Fixed & Open \\
\hline Chad & 1994-2011 & Developing & Fixed & Open \\
\hline Chile & 1989-2013 & Developing & Flexible & Open \\
\hline China & 1990-2013 & Developing & Fixed & Closed \\
\hline Colombia & 1989-2013 & Developing & Flexible & Closed \\
\hline Côte d'Ivoire & 1989-2012 & Developing & Fixed & Open \\
\hline Croatia & 1993-2013 & Developing & Flexible & Open \\
\hline Cyprus & 1989-2013 & Advanced & Fixed & Open \\
\hline Czech Republic & 1994-2013 & Developing & Flexible & Open \\
\hline Denmark & 1989-2013 & Advanced & Fixed & Open \\
\hline Djibouti & 1989-2008 & Developing & Fixed & Open \\
\hline Dominican Republic & 1989-2013 & Developing & Flexible & Open \\
\hline Ecuador & 1989-2013 & Developing & NA & Closed \\
\hline Egypt & 1989-2013 & Developing & Fixed & Closed \\
\hline El Salvador & 1989-2013 & Developing & Fixed & Open \\
\hline Estonia & 1993-2013 & Developing & Fixed & Open \\
\hline Ethiopia & 1991-2013 & Developing & Varies & Closed \\
\hline Fiji & 1989-2013 & Developing & Flexible & Open \\
\hline Finland & 1989-2013 & Advanced & Fixed & Open \\
\hline France & 1989-2013 & Advanced & Fixed & Closed \\
\hline Georgia & $1997-2013$ & Developing & Flexible & Open \\
\hline Germany & 1989-2013 & Advanced & Flexible & Open \\
\hline Ghana & 1989-2013 & Developing & Flexible & Open \\
\hline Greece & 1989-2013 & Advanced & Fixed & Closed \\
\hline Guatemala & 1989-2013 & Developing & Flexible & Closed \\
\hline Guyana & 1989-2013 & Developing & Fixed & Open \\
\hline
\end{tabular}




\begin{tabular}{|c|c|c|c|c|}
\hline Hungary & 1989-2013 & Developing & Flexible & Open \\
\hline India & 1989-2013 & Developing & Flexible & Closed \\
\hline Indonesia & 1989-2013 & Developing & Flexible & Closed \\
\hline Iran & 1989-2012 & Developing & Flexible & Closed \\
\hline Ireland & 1989-2013 & Advanced & Fixed & Open \\
\hline Israel & 1989-2013 & Advanced & Flexible & Open \\
\hline Italy & 1989-2013 & Advanced & Fixed & Closed \\
\hline Jamaica & 1990-2013 & Developing & Flexible & Open \\
\hline Japan & 1989-2013 & Advanced & Flexible & Closed \\
\hline Jordan & 1989-2013 & Developing & Fixed & Open \\
\hline Kazakhstan & 1994-2013 & Developing & Flexible & Open \\
\hline Kenya & 1989-2013 & Developing & Flexible & Closed \\
\hline Korea & 1989-2013 & Developing & Flexible & Open \\
\hline Kyrgyzstan & 1993-2013 & Developing & Flexible & Open \\
\hline Laos & 1993-2012 & Developing & Flexible & Open \\
\hline Latvia & 1994-2013 & Developing & Flexible & Open \\
\hline Lebanon & 1991-2013 & Developing & Fixed & Open \\
\hline Lesotho & 1989-2013 & Developing & Fixed & Open \\
\hline Lithuania & 1994-2013 & Developing & Fixed & Open \\
\hline Luxembourg & 1989-2013 & Advanced & Fixed & Open \\
\hline Macedonia & 1997-2013 & Developing & Fixed & Open \\
\hline Madagascar & 1989-2013 & Developing & Flexible & Open \\
\hline Malawi & 1989-2013 & Developing & Flexible & Open \\
\hline Malaysia & 1989-2013 & Developing & Flexible & Open \\
\hline Mali & 1989-2013 & Developing & Fixed & Open \\
\hline Malta & 1989-2013 & Advanced & Fixed & Open \\
\hline Mauritania & 1989-2009 & Developing & Flexible & Open \\
\hline Mauritius & 1989-2013 & Developing & Flexible & Open \\
\hline Mexico & 1989-2013 & Developing & Flexible & Closed \\
\hline Moldova & 1994-2013 & Developing & Flexible & Open \\
\hline Mongolia & 1991-2012 & Developing & Flexible & Open \\
\hline Morocco & 1989-2013 & Developing & Fixed & Open \\
\hline Mozambique & 1989-2010 & Developing & Flexible & Closed \\
\hline Namibia & 1991-2013 & Developing & Fixed & Open \\
\hline Nepal & 1989-2013 & Developing & Fixed & Closed \\
\hline Netherlands & 1989-2013 & Advanced & Fixed & Open \\
\hline New Zealand & 1989-2013 & Advanced & Flexible & Closed \\
\hline Nicaragua & 1991-2013 & Developing & Flexible & Open \\
\hline Nigeria & 1989-2013 & Developing & Flexible & Closed \\
\hline Norway & 1989-2013 & Advanced & Flexible & Open \\
\hline Oman & 1989-2013 & Developing & Fixed & Open \\
\hline Papua New Guinea & 1989-2013 & Developing & Flexible & Open \\
\hline Paraguay & 1990-2013 & Developing & Flexible & Open \\
\hline Peru & 1990-2013 & Developing & Flexible & Closed \\
\hline Philippines & 1989-2013 & Developing & Flexible & Open \\
\hline Poland & 1989-2013 & Developing & Flexible & Open \\
\hline Portugal & 1989-2013 & Advanced & Fixed & Open \\
\hline Romania & 1989-2013 & Developing & Flexible & Open \\
\hline Russia & 1993-2013 & Developing & Flexible & Closed \\
\hline Saudi Arabia & 1989-2013 & Developing & Fixed & Open \\
\hline Senegal & 1989-2010 & Developing & Fixed & Open \\
\hline Serbia & 1998-2013 & Developing & NA & Open \\
\hline
\end{tabular}




\begin{tabular}{|c|c|c|c|c|}
\hline Seychelles & 1989-2013 & Developing & Flexible & Open \\
\hline Sierra Leone & 1989-2013 & Developing & Flexible & Closed \\
\hline Singapore & 1989-2013 & Advanced & Flexible & Open \\
\hline Slovak Republic & 1994-2013 & Developing & Flexible & Open \\
\hline Slovenia & 1993-2013 & Advanced & Fixed & Open \\
\hline South Africa & 1989-2013 & Developing & Flexible & Closed \\
\hline Spain & 1989-2013 & Advanced & Fixed & Closed \\
\hline Swaziland & 1989-2013 & Developing & Fixed & Open \\
\hline Sweden & 1989-2013 & Advanced & Flexible & Open \\
\hline Switzerland & 1989-2013 & Advanced & Flexible & Open \\
\hline Syria & 1989-2010 & Developing & NA & Open \\
\hline Tanzania & 1989-2013 & Developing & Flexible & Closed \\
\hline Thailand & 1989-2013 & Developing & Flexible & Open \\
\hline Tunisia & 1989-2013 & Developing & Flexible & Open \\
\hline Turkey & 1989-2013 & Developing & Flexible & Closed \\
\hline United Arab Emirates & 1998-2012 & Advanced & Fixed & Open \\
\hline Uganda & 1989-2013 & Developing & Flexible & Closed \\
\hline Ukraine & 1994-2013 & Developing & Fixed & Open \\
\hline United Kingdom & 1989-2013 & Advanced & Flexible & Closed \\
\hline United States & 1989-2013 & Advanced & Flexible & Closed \\
\hline Uruguay & 1989-2013 & Developing & Flexible & Closed \\
\hline Venezuela & $1992-2013$ & Developing & Flexible & Closed \\
\hline Vietnam & 1989-2013 & Developing & Varies & Open \\
\hline Yemen & 1991-2013 & Developing & Fixed & Open \\
\hline Zambia & 1989-2013 & Developing & Flexible & Open \\
\hline
\end{tabular}

Notes: The exchange-rate classification varies across years. The table values are for the median year. "NA" denotes that data are unavailable. "Varies" denotes the there are equal numbers of fixed and flexible episodes in the sample. 125 countries in total. 


\section{Additional Results}
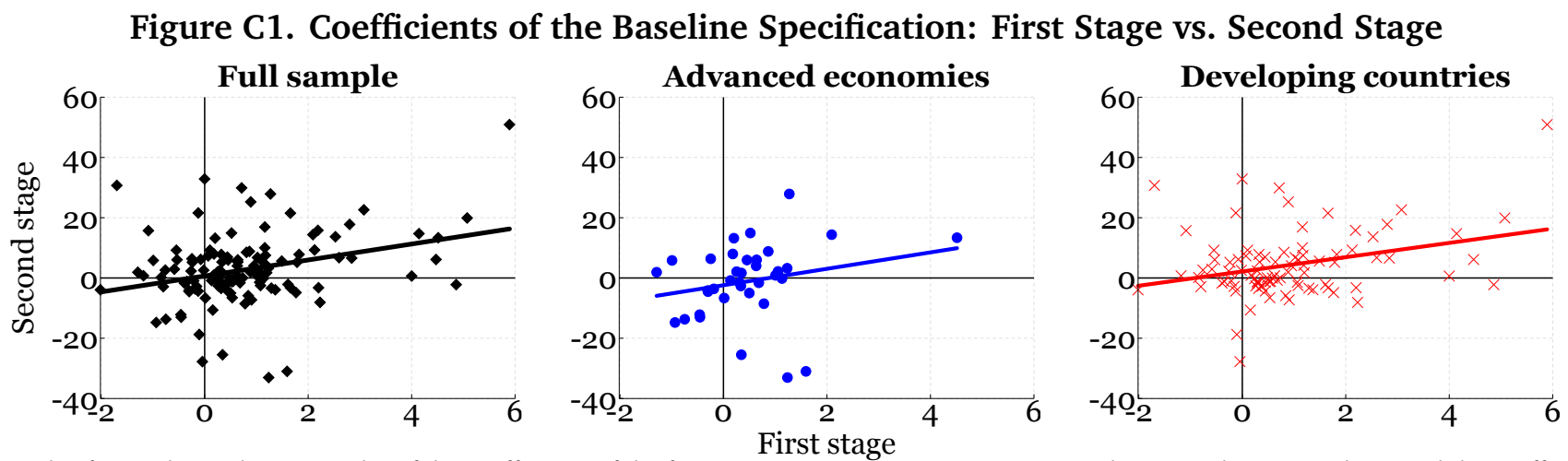

Notes: This figure shows the scatterplot of the coefficients of the first-stage regression (government spending on military spending) and the coefficients of the second-stage regression (the real effective exchange rate on military spending) in all countries (left panel), advanced economies (middle panel), and developing economies (right panel). The solid lines depict linear fit.

Figure C2. The Share of Arms Deliveries in Total Military Expenditure, 2002-2012

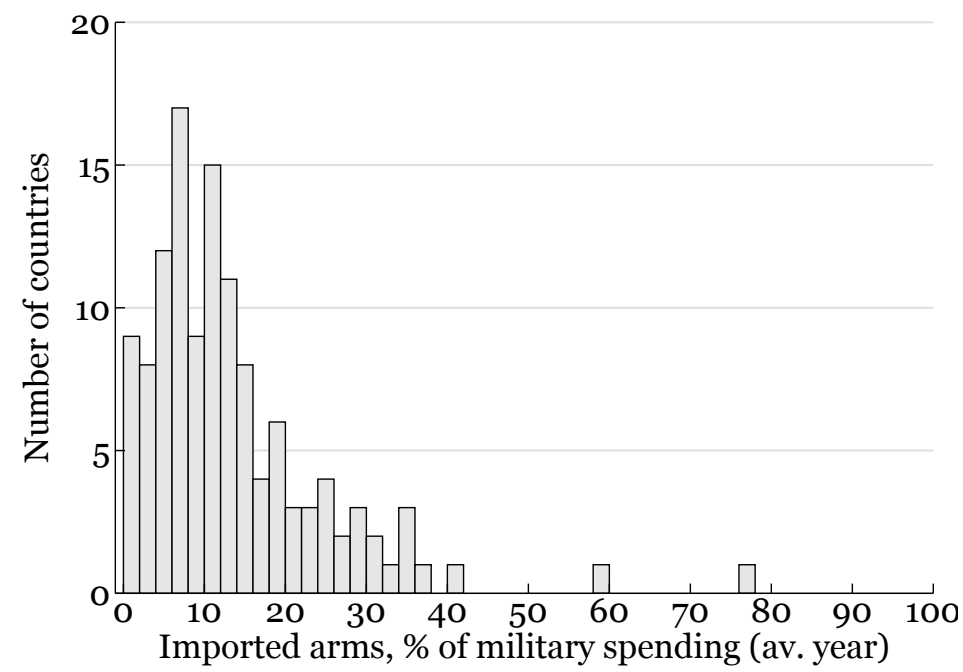

Notes: The distribution of the countries' mean shares. Data are from the U.S. Department of State's World Military Expenditures and Arms Transfers (WMEAT) 2015, 33rd edition, published in December 2015. The country sample is consistent with the baseline, excluding the Seychelles (data not available). The shares are computed from the individual series of imported arms deliveries and total military expenditures; values over 100 percent, which most likely represent a timing mismatch between payment and delivery, (about 2 percent of the initial number of observations) are dropped. 
Table C1. Real Exchange-Rate Response in Advanced and Developing Countries: Robustness to Controls

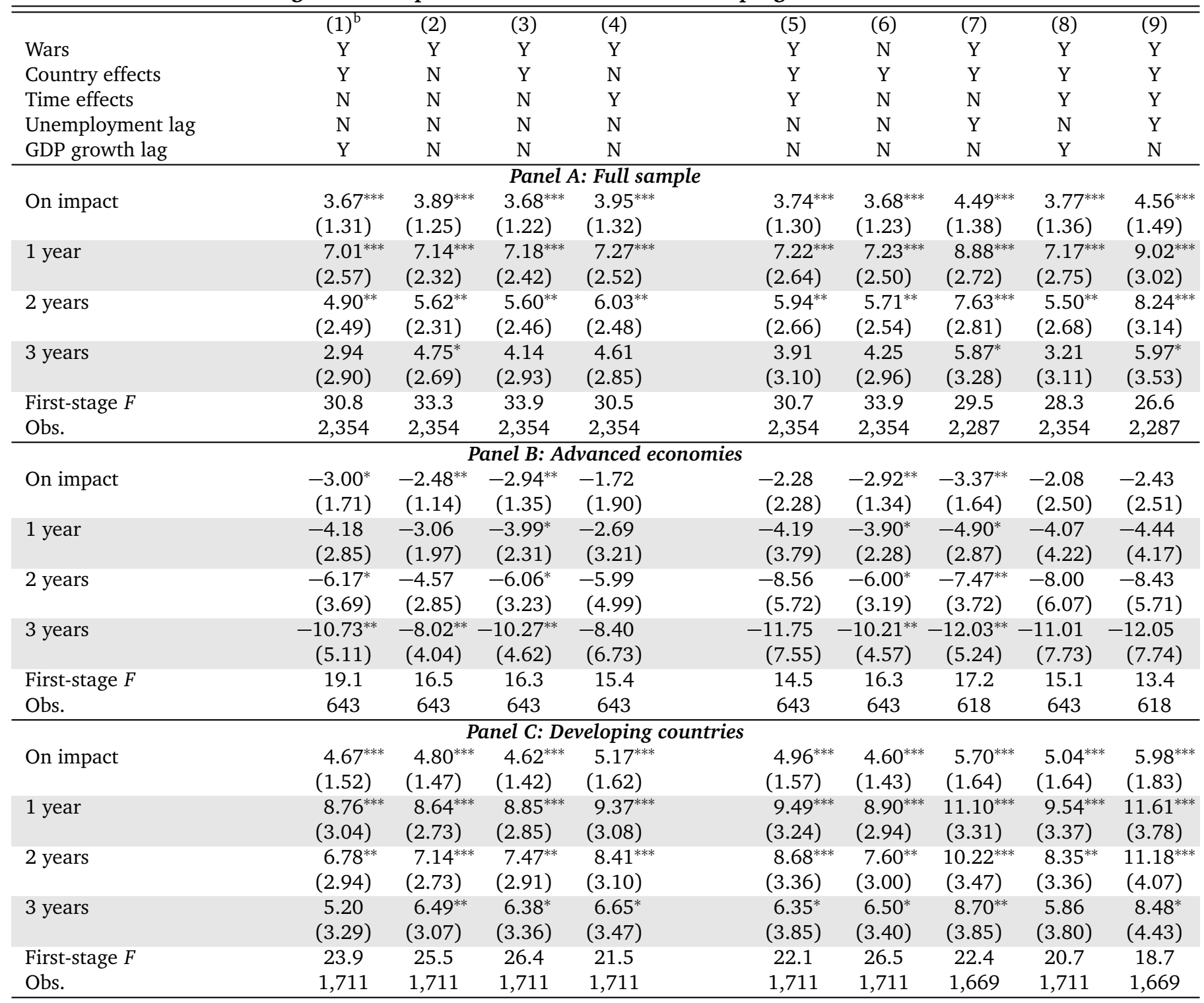

Notes: This table reports the response of the REER to an increase in $g$ shock of 1 percent of GDP. We use the World Bank (2000) classification. The superscript $b$ denotes our baseline specification. The column with a superscript $b$ shows the baseline results. 
Table C2. Current Account-to-GDP Response: Robustness to Controls

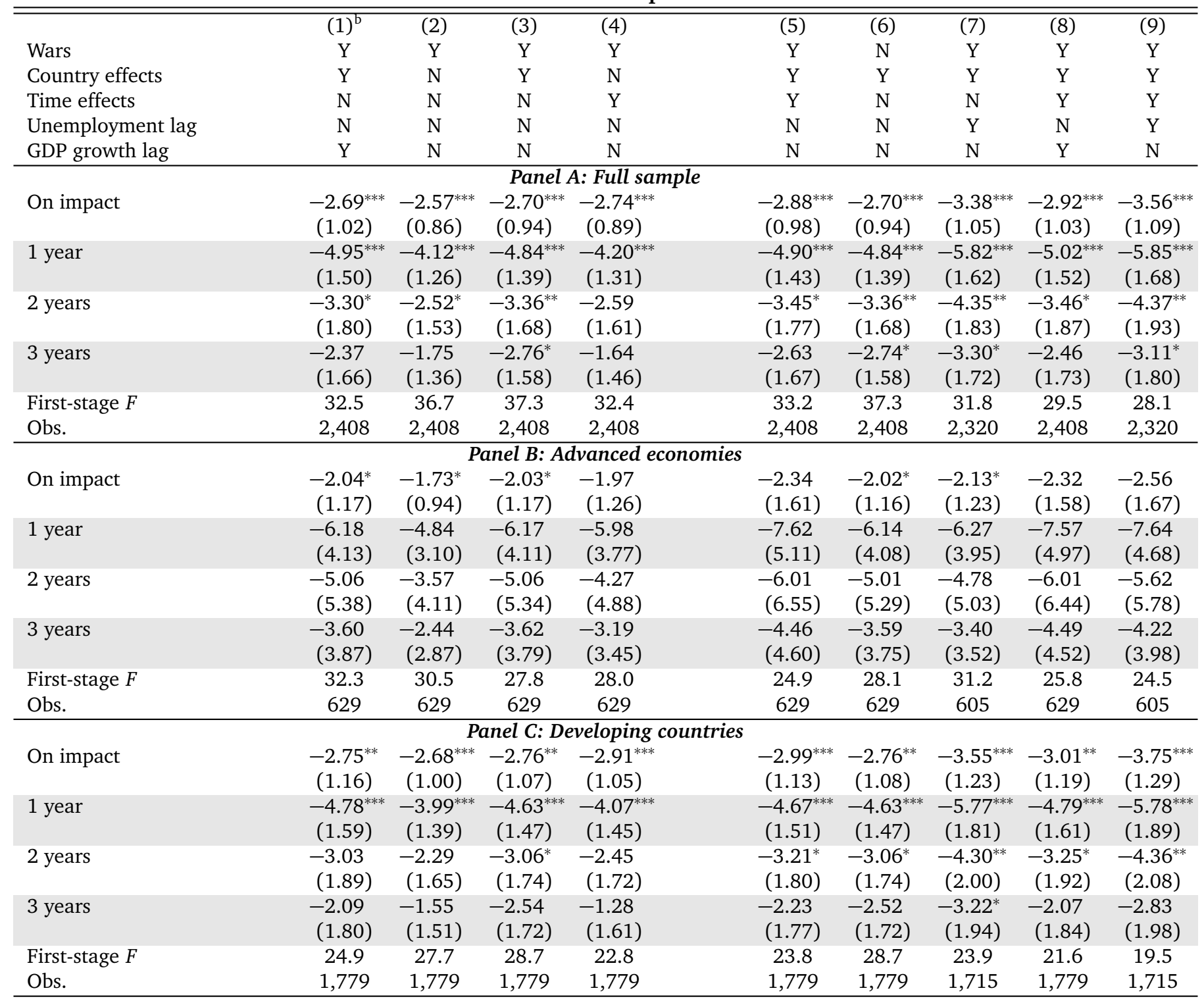

Notes: This table reports the response of the current account-to-output ratio to an increase in $g$ of 1 percent of GDP. The $g$ shocks are constructed using military spending as an instrument for total government spending. The column with a superscript $b$ shows the baseline results. 
Table C3. Net Exports-to-GDP Ratio Response

\begin{tabular}{|c|c|c|c|c|c|c|c|c|c|}
\hline & $(1)^{b}$ & (2) & (3) & (4) & (5) & (6) & (7) & (8) & (9) \\
\hline Wars & $\mathrm{Y}$ & $\mathrm{Y}$ & $\mathrm{Y}$ & $\mathrm{Y}$ & $\mathrm{Y}$ & $\mathrm{N}$ & $\mathrm{Y}$ & $\mathrm{Y}$ & $\mathrm{Y}$ \\
\hline Country effects & $\mathrm{Y}$ & $\mathrm{N}$ & $\mathrm{Y}$ & $\mathrm{N}$ & $\mathrm{Y}$ & $\mathrm{Y}$ & $\mathrm{Y}$ & $\mathrm{Y}$ & $\mathrm{Y}$ \\
\hline Time effects & $\mathrm{N}$ & $\mathrm{N}$ & $\mathrm{N}$ & $\mathrm{Y}$ & $\mathrm{Y}$ & $\mathrm{N}$ & $\mathrm{N}$ & $\mathrm{Y}$ & $\mathrm{Y}$ \\
\hline GDP growth lag & $\mathrm{Y}$ & $\mathrm{N}$ & $\mathrm{N}$ & $\mathrm{N}$ & $\mathrm{N}$ & $\mathrm{N}$ & $\mathrm{N}$ & $\mathrm{Y}$ & $\mathrm{N}$ \\
\hline \multicolumn{10}{|c|}{ Panel A: Full sample } \\
\hline On impact & $\begin{array}{c}-4.30^{* * *} \\
(1.26)\end{array}$ & $\begin{array}{c}-3.93^{* * *} \\
(1.02)\end{array}$ & $\begin{array}{c}-4.13^{* * *} \\
(1.14)\end{array}$ & $\begin{array}{c}-4.15^{* * *} \\
(1.10)\end{array}$ & $\begin{array}{c}-4.41^{* * *} \\
(1.25)\end{array}$ & $\begin{array}{c}-4.12^{* * *} \\
(1.14)\end{array}$ & $\begin{array}{c}-4.73^{* * *} \\
(1.26)\end{array}$ & $\begin{array}{c}-4.60^{* * *} \\
(1.37)\end{array}$ & $\begin{array}{c}-5.04^{* * *} \\
(1.40)\end{array}$ \\
\hline 1 year & $\begin{array}{c}-7.23^{\text {*** }} \\
(1.99)\end{array}$ & $\begin{array}{c}-6.54^{* * *} \\
(1.67)\end{array}$ & $\begin{array}{c}-6.85^{\text {*** }} \\
(1.81)\end{array}$ & $\begin{array}{c}-6.74^{* * *} \\
(1.81)\end{array}$ & $\begin{array}{c}-7.02^{\text {*** }} \\
(1.98)\end{array}$ & $\begin{array}{c}-6.86^{* * *} \\
(1.82)\end{array}$ & $\begin{array}{c}-7.39^{* * *} \\
(2.03)\end{array}$ & $\begin{array}{c}-7.41^{* * *} \\
(2.16)\end{array}$ & $\begin{array}{c}-7.48^{* * *} \\
(2.20)\end{array}$ \\
\hline 2 years & $\begin{array}{c}-5.06^{* *} \\
(2.11)\end{array}$ & $\begin{array}{c}-4.66^{* *} \\
(1.82)\end{array}$ & $\begin{array}{c}-4.88^{* *} \\
(1.93)\end{array}$ & $\begin{array}{c}-4.93^{* *} \\
(2.01)\end{array}$ & $\begin{array}{c}-5.07^{* *} \\
(2.14)\end{array}$ & $\begin{array}{c}-4.89^{* *} \\
(1.94)\end{array}$ & $\begin{array}{c}-5.05^{* *} \\
(2.16)\end{array}$ & $\begin{array}{c}-5.28^{* *} \\
(2.31)\end{array}$ & $\begin{array}{c}-5.18^{* *} \\
(2.36)\end{array}$ \\
\hline 3 years & $\begin{array}{c}-4.34^{* *} \\
(2.02)\end{array}$ & $\begin{array}{c}-3.90^{* *} \\
(1.80)\end{array}$ & $\begin{array}{c}-4.34^{* *} \\
(1.84)\end{array}$ & $\begin{array}{c}-4.17^{* *} \\
(1.96)\end{array}$ & $\begin{array}{c}-4.51^{* *} \\
(2.01)\end{array}$ & $\begin{array}{c}-4.35^{* *} \\
(1.84)\end{array}$ & $\begin{array}{c}-4.54^{* *} \\
(2.10)\end{array}$ & $\begin{array}{c}-4.60^{* *} \\
(2.17)\end{array}$ & $\begin{array}{c}-4.70^{* *} \\
(2.27)\end{array}$ \\
\hline \multicolumn{10}{|c|}{ Panel B: Advanced economies } \\
\hline On impact & $\begin{array}{c}-5.68 \\
(3.92)\end{array}$ & $\begin{array}{c}-5.27 \\
(3.63)\end{array}$ & $\begin{array}{c}-5.72 \\
(4.13)\end{array}$ & $\begin{array}{c}-6.11 \\
(3.94)\end{array}$ & $\begin{array}{c}-6.80 \\
(4.70)\end{array}$ & $\begin{array}{c}-5.69 \\
(4.09)\end{array}$ & $\begin{array}{c}-5.93 \\
(4.22)\end{array}$ & $\begin{array}{c}-6.64 \\
(4.36)\end{array}$ & $\begin{array}{c}-7.17 \\
(4.77)\end{array}$ \\
\hline 1 year & $\begin{array}{c}-9.04 \\
(6.82)\end{array}$ & $\begin{array}{c}-8.83 \\
(6.63)\end{array}$ & $\begin{array}{c}-9.05 \\
(7.01)\end{array}$ & $\begin{array}{r}-10.28 \\
(7.44)\end{array}$ & $\begin{array}{r}-10.80 \\
(8.26)\end{array}$ & $\begin{array}{c}-8.99 \\
(6.95)\end{array}$ & $\begin{array}{c}-9.23 \\
(6.97)\end{array}$ & $\begin{array}{r}-10.68 \\
(7.95)\end{array}$ & $\begin{array}{r}-11.10 \\
(8.05)\end{array}$ \\
\hline 2 years & $\begin{array}{c}-5.87 \\
(7.02)\end{array}$ & $\begin{array}{c}-6.21 \\
(6.97)\end{array}$ & $\begin{array}{c}-5.88 \\
(7.09)\end{array}$ & $\begin{array}{c}-7.06 \\
(8.04)\end{array}$ & $\begin{array}{c}-6.75 \\
(8.61)\end{array}$ & $\begin{array}{c}-5.84 \\
(7.02)\end{array}$ & $\begin{array}{c}-5.34 \\
(6.84)\end{array}$ & $\begin{array}{c}-6.73 \\
(8.42)\end{array}$ & $\begin{array}{c}-6.33 \\
(8.07)\end{array}$ \\
\hline 3 years & $\begin{array}{c}-3.04 \\
(5.29)\end{array}$ & $\begin{array}{c}-3.99 \\
(5.90)\end{array}$ & $\begin{array}{c}-3.05 \\
(5.24)\end{array}$ & $\begin{array}{c}-4.84 \\
(6.85)\end{array}$ & $\begin{array}{c}-3.82 \\
(6.46)\end{array}$ & $\begin{array}{c}-3.02 \\
(5.19)\end{array}$ & $\begin{array}{c}-2.32 \\
(4.86)\end{array}$ & $\begin{array}{c}-3.91 \\
(6.40)\end{array}$ & $\begin{array}{c}-3.21 \\
(5.78)\end{array}$ \\
\hline First-stage $F$ & 18.2 & 18.4 & 17.7 & 18.2 & 17.0 & 17.9 & 18.5 & 16.2 & 16.0 \\
\hline Obs. & 636 & 636 & 636 & 636 & 636 & 636 & 610 & 636 & 610 \\
\hline \multicolumn{10}{|c|}{ Panel C: Developing countries } \\
\hline On impact & $\begin{array}{c}-4.00^{\text {**** }} \\
(1.27)\end{array}$ & $\begin{array}{c}-3.73^{\text {**** }} \\
(1.04)\end{array}$ & $\begin{array}{c}-3.88^{\text {*** }} \\
(1.14)\end{array}$ & $\begin{array}{c}-4.08^{* * *} \\
(1.21)\end{array}$ & $\begin{array}{c}-4.28^{* * *} \\
(1.35)\end{array}$ & $\begin{array}{c}-3.87^{\text {*** }} \\
(1.14)\end{array}$ & $\begin{array}{c}-4.53^{\text {*** }} \\
(1.30)\end{array}$ & $\begin{array}{c}-4.41^{* * *} \\
(1.46)\end{array}$ & $\begin{array}{c}-4.99^{* * *} \\
(1.57)\end{array}$ \\
\hline 1 year & $\begin{array}{c}-6.87^{\text {**** }} \\
(1.99)\end{array}$ & $\begin{array}{c}-6.18^{* * *} \\
(1.64)\end{array}$ & $\begin{array}{c}-6.49^{* * *} \\
(1.79)\end{array}$ & $\begin{array}{c}-6.39^{* * *} \\
(1.83)\end{array}$ & $\begin{array}{c}-6.66^{* * *} \\
(2.01)\end{array}$ & $\begin{array}{c}-6.51^{* * *} \\
(1.80)\end{array}$ & $\begin{array}{c}-7.10^{* * *} \\
(2.08)\end{array}$ & $\begin{array}{c}-7.02^{* * *} \\
(2.21)\end{array}$ & $\begin{array}{c}-7.14^{* * *} \\
(2.31)\end{array}$ \\
\hline 2 years & $\begin{array}{c}-4.94^{* *} \\
(2.15)\end{array}$ & $\begin{array}{c}-4.35^{* *} \\
(1.78)\end{array}$ & $\begin{array}{c}-4.71^{* *} \\
(1.95)\end{array}$ & $\begin{array}{c}-4.72^{* *} \\
(1.97)\end{array}$ & $\begin{array}{c}-4.98^{* *} \\
(2.14)\end{array}$ & $\begin{array}{c}-4.73^{* *} \\
(1.96)\end{array}$ & $\begin{array}{c}-4.99^{* *} \\
(2.27)\end{array}$ & $\begin{array}{c}-5.23^{* *} \\
(2.33)\end{array}$ & $\begin{array}{c}-5.18^{* *} \\
(2.46)\end{array}$ \\
\hline 3 years & $\begin{array}{c}-4.55^{* *} \\
(2.22)\end{array}$ & $\begin{array}{c}-3.83^{* *} \\
(1.91)\end{array}$ & $\begin{array}{c}-4.52^{* *} \\
(2.01)\end{array}$ & $\begin{array}{c}-4.04^{* *} \\
(2.06)\end{array}$ & $\begin{array}{c}-4.63^{* *} \\
(2.17)\end{array}$ & $\begin{array}{c}-4.54^{* *} \\
(2.02)\end{array}$ & $\begin{array}{c}-4.91^{* *} \\
(2.39)\end{array}$ & $\begin{array}{c}-4.75^{* *} \\
(2.36)\end{array}$ & $\begin{array}{r}-5.00^{*} \\
(2.55)\end{array}$ \\
\hline First-stage $F$ & 21.2 & 25.5 & 24.9 & 20.6 & 19.9 & 24.9 & 20.7 & 17.6 & 16.8 \\
\hline Obs. & 1,733 & 1,733 & 1,733 & 1,733 & 1,733 & 1,733 & 1,674 & 1,733 & 1,674 \\
\hline
\end{tabular}

Notes: This table reports the response of the net exports-to-output ratio to an increase in $g$ of 1 percent of GDP. The $g$ shocks are constructed using military spending as an instrument for total government spending. The superscript $b$ denotes our baseline specification. 
Table C4. Consumption Response: Robustness to Controls

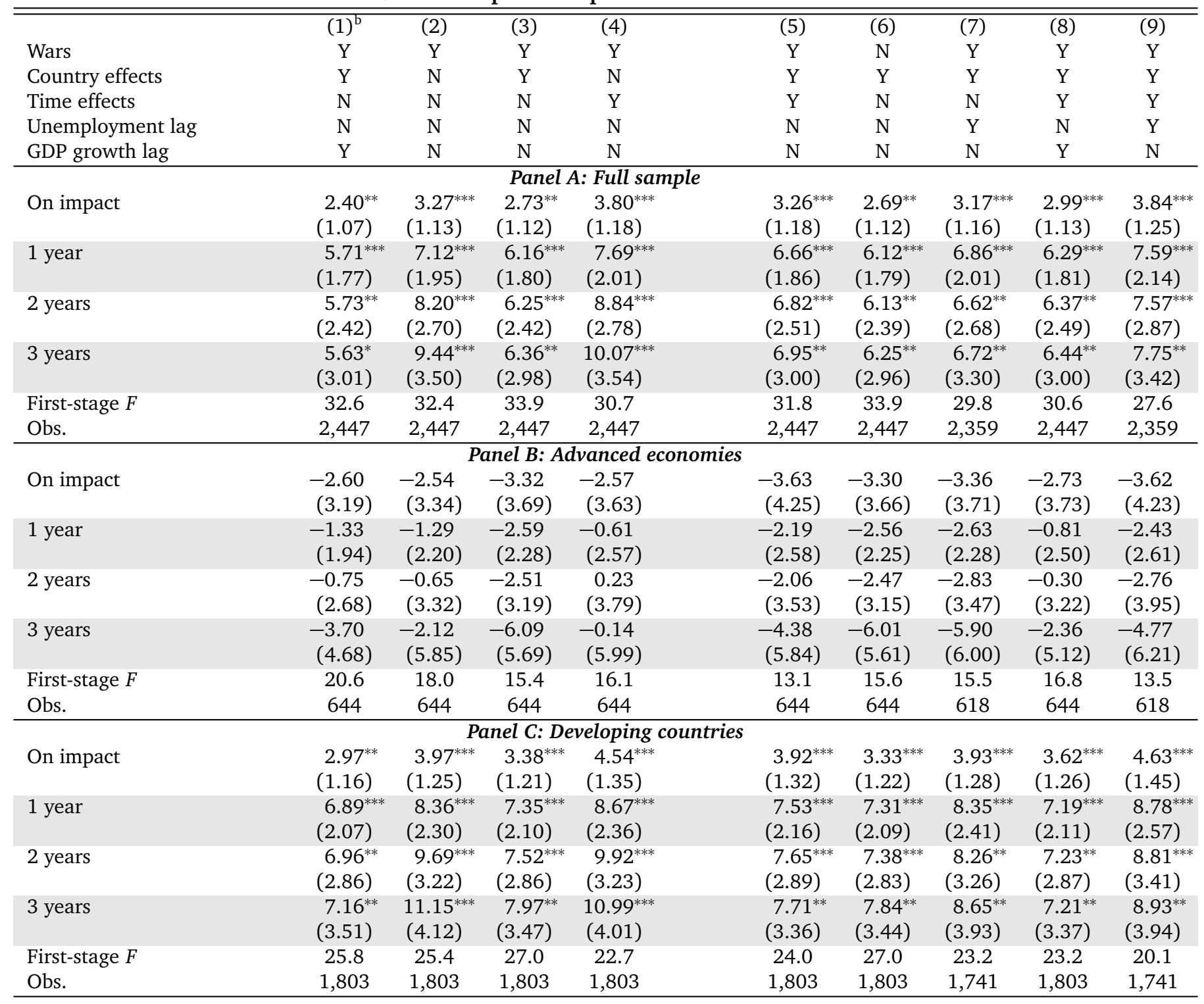

Notes: This table reports the response of consumption (in percent) to an increase in $g$ of 1 percent of GDP. The $g$ shocks are constructed using military spending as an instrument for total government spending. The column with a superscript $b$ shows the baseline results. 
Table C5. Real Exchange-Rate Response to Government-Spending Shocks: Middle- and Low-Income Countries

\begin{tabular}{|c|c|c|c|c|c|c|c|c|c|}
\hline & $(1)^{b}$ & (2) & (3) & (4) & (5) & (6) & (7) & (8) & (9) \\
\hline Wars & $\mathrm{Y}$ & $\mathrm{Y}$ & $\mathrm{Y}$ & $\mathrm{Y}$ & $\mathrm{Y}$ & $\mathrm{N}$ & $\mathrm{Y}$ & $\mathrm{Y}$ & $\mathrm{Y}$ \\
\hline Country effects & $\mathrm{Y}$ & $\mathrm{N}$ & $\mathrm{Y}$ & $\mathrm{N}$ & $\mathrm{Y}$ & $\mathrm{Y}$ & $\mathrm{Y}$ & $\mathrm{Y}$ & $\mathrm{Y}$ \\
\hline Time effects & $\mathrm{N}$ & $\mathrm{N}$ & $\mathrm{N}$ & $\mathrm{Y}$ & $\mathrm{Y}$ & $\mathrm{N}$ & $\mathrm{N}$ & $\mathrm{Y}$ & $\mathrm{Y}$ \\
\hline GDP growth lag & $\mathrm{Y}$ & $\mathrm{N}$ & $\mathrm{N}$ & $\mathrm{N}$ & $\mathrm{N}$ & $\mathrm{N}$ & $\mathrm{N}$ & $\mathrm{Y}$ & $\mathrm{N}$ \\
\hline \multicolumn{10}{|c|}{ Panel A: Middle-income countries } \\
\hline On impact & $3.92^{* *}$ & $4.08^{* *}$ & $3.94^{* *}$ & $4.90^{* * *}$ & $4.81^{* *}$ & $3.97^{* *}$ & $5.37^{* *}$ & $4.79^{* *}$ & $6.14^{* *}$ \\
\hline \multirow[t]{2}{*}{1 year } & $8.66^{* *}$ & $8.78^{* * *}$ & $8.88^{* *}$ & $10.45^{* * *}$ & $10.64^{* *}$ & $9.28^{* *}$ & $11.68^{* * *}$ & $10.52^{* *}$ & $13.00^{* * *}$ \\
\hline & $(3.36)$ & $(3.71)$ & $(3.50)$ & $(3.96)$ & $(4.24)$ & $(3.88)$ & $(4.06)$ & $(4.38)$ & $(4.89)$ \\
\hline \multirow[t]{2}{*}{2 years } & 4.93 & $5.99^{*}$ & $6.11^{*}$ & $8.39^{* *}$ & $8.61^{* *}$ & $6.70^{*}$ & $9.61^{* *}$ & $7.99^{* *}$ & $11.45^{* *}$ \\
\hline & $(3.17)$ & $(3.20)$ & $(3.29)$ & $(3.95)$ & $(4.19)$ & $(3.65)$ & $(3.84)$ & $(4.07)$ & $(4.98)$ \\
\hline \multirow[t]{2}{*}{3 years } & 1.98 & 4.13 & 3.82 & 5.31 & 4.88 & 4.41 & $6.96^{*}$ & 4.06 & 7.04 \\
\hline & $(3.45)$ & (3.57) & (3.69) & $(4.24)$ & $(4.73)$ & (3.83) & (4.19) & $(4.50)$ & (5.39) \\
\hline On impact & $(2.78)$ & $(2.62)$ & $(2.43)$ & (3.24) & $(2.75)$ & $(2.40)$ & (2.59) & $(2.83)$ & (3.10) \\
\hline \multirow[t]{2}{*}{1 year } & $8.42^{*}$ & $8.07^{*}$ & $8.35^{*}$ & $8.48^{*}$ & $8.71^{*}$ & $8.15^{*}$ & $9.47^{*}$ & $8.78^{*}$ & $9.90^{*}$ \\
\hline & $(4.38)$ & $(4.68)$ & $(4.40)$ & $(4.60)$ & $(4.63)$ & $(4.28)$ & (5.09) & (4.79) & $(5.62)$ \\
\hline \multirow[t]{2}{*}{2 years } & 9.25 & $8.88^{*}$ & $9.28^{*}$ & $10.11^{*}$ & $10.65^{*}$ & $9.27^{*}$ & 10.33 & 10.60 & 11.79 \\
\hline & $(5.08)$ & $(5.67)$ & $(5.44)$ & $(5.72)$ & $(6.36)$ & $(5.43)$ & $(6.29)$ & $(6.46)$ & $(7.28)$ \\
\hline \multirow[t]{2}{*}{3 years } & 10.28 & $10.93^{*}$ & 10.53 & 12.35 & 12.44 & 10.56 & 11.27 & 12.37 & 13.14 \\
\hline & $(6.63)$ & (7.27) & (7.13) & $(8.05)$ & $(8.81)$ & (7.12) & (7.74) & $(8.93)$ & (9.33) \\
\hline First-stage $F$ & 9.7 & 7.7 & 10.4 & 5.8 & 8.3 & 11.0 & 9.4 & 8.1 & 7.2 \\
\hline Obs. & 574 & 574 & 574 & 574 & 574 & 574 & 566 & 574 & 566 \\
\hline
\end{tabular}

Notes: This table reports the response of the real effective exchange rate to an increase in $g$ shock of 1 percent of GDP. We use the World Banks's classification of countries in 2000: middle-income countries (both upper- and lower-middle income) and low-income countries. The superscript $b$ denotes our baseline specification. 
Table C6. Responses to Government-Spending Shocks under Fixed and Floating Exchange-Rate Regimes

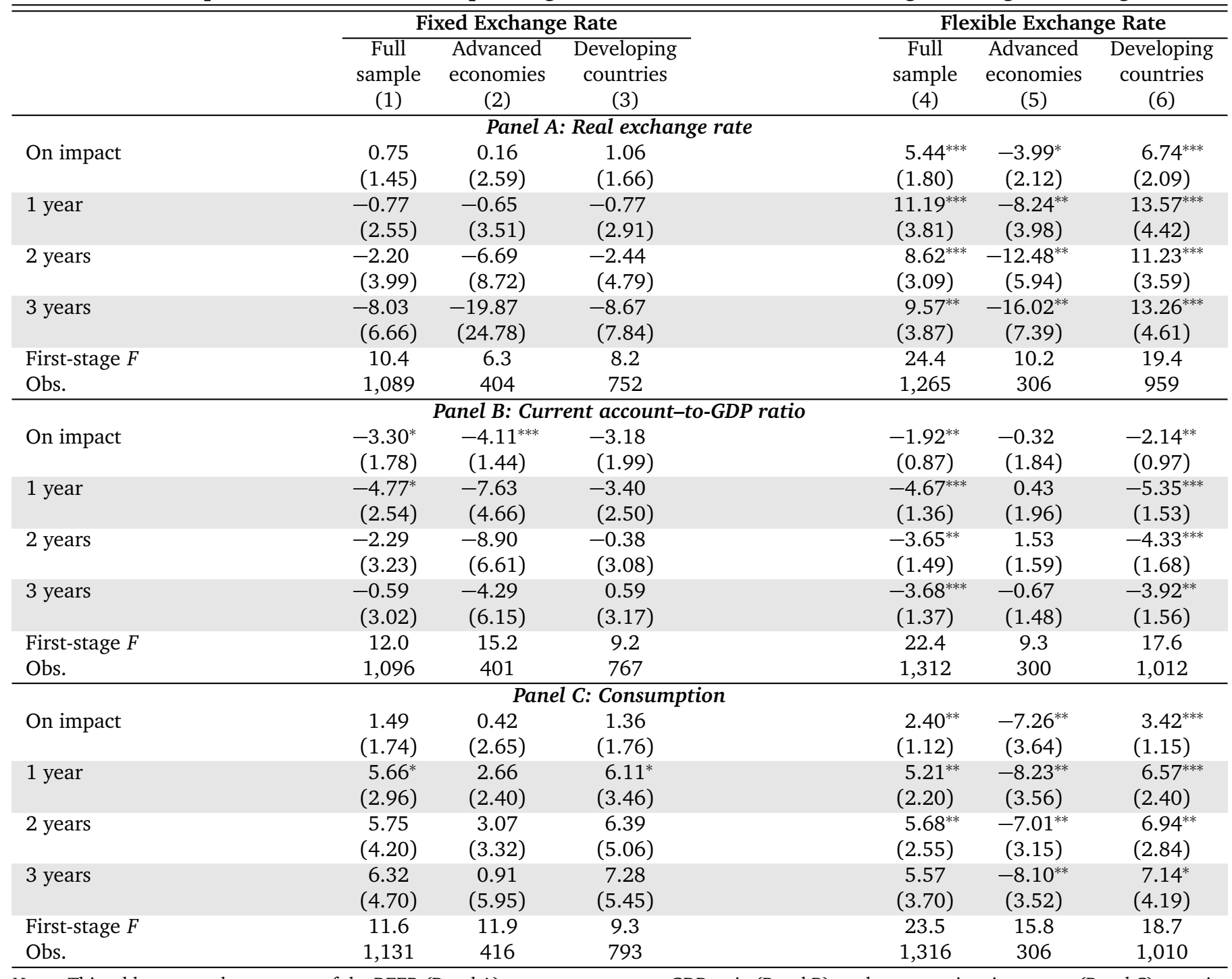

Notes: This table reports the response of the REER (Panel A), current account-to-GDP ratio (Panel B), and consumption, in percent (Panel C) to an increase in $g$ shock of 1 percent of GDP by exchange-rate regimes, using the baseline specification. The $g$ shocks are constructed using military spending as an instrument for total government spending. 
Table C7. Responses to Government-Spending Shocks by Trade Openness

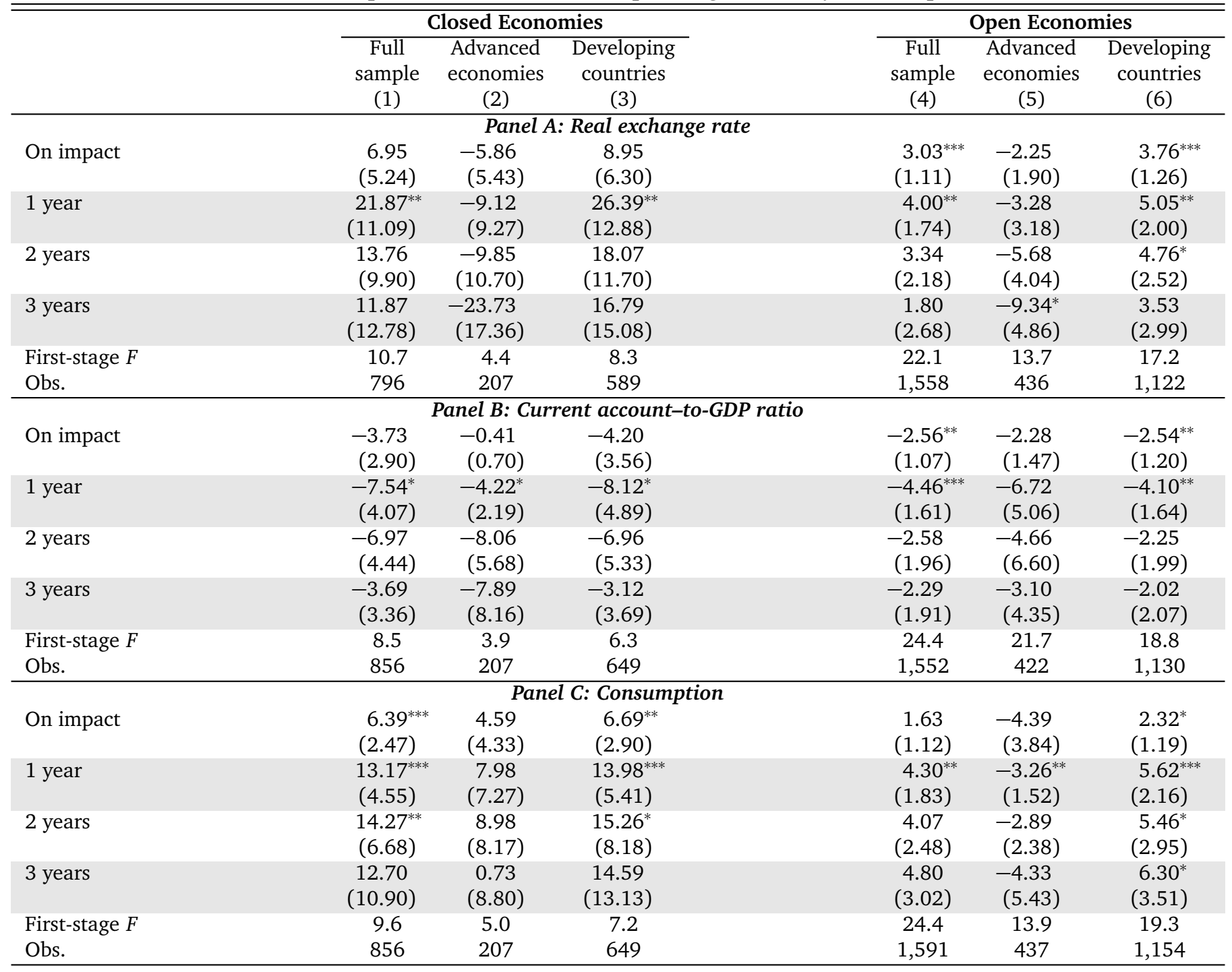

Notes: This table reports the response of the REER (Panel A), current account-to-GDP ratio (Panel B), and consumption, in percent (Panel C) to an increase in $g$ shock of 1 percent of GDP by trade openness, using the baseline specification. A country is open if its total trade share in GDP exceeds 60 percent. The $g$ shocks are constructed using military spending as an instrument for total government spending.

Table C8. Excluding Countries with Long Civil Wars

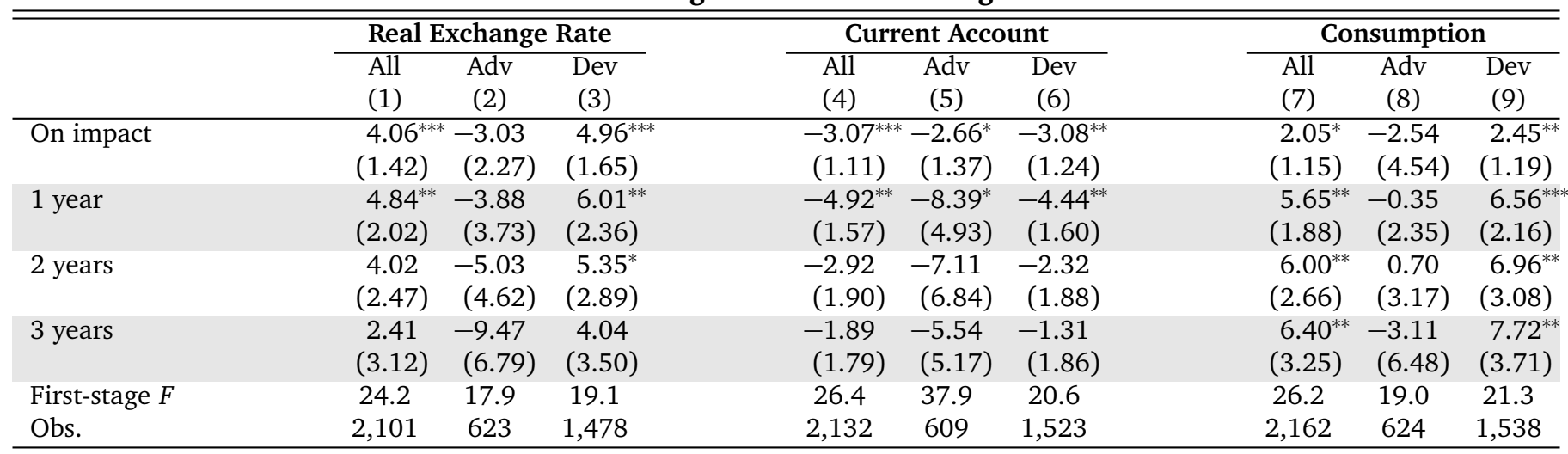

Notes: This table reports the response of the real exchange rate, current account-to-GDP ratio, and consumption (in percent) to an increase in $g$ of 1 percent of GDP. The $g$ shocks are constructed using military spending as an instrument for total government spending. We estimate the baseline specification for the sample excluding countries with at least 10 years of wars. These countries are Algeria, Burundi, Chad, Colombia, Ethiopia, India, Indonesia, Iran, Israel, Nepal, Peru, Pakistan, the Philippines, Russia, Rwanda, Sri Lanka, Thailand, Turkey, and Uganda. The results are similar to those from other specifications. 
Table C9. Controlling for Financial Crises

\begin{tabular}{|c|c|c|c|c|c|c|c|c|c|}
\hline & \multicolumn{3}{|c|}{ Real Exchange Rate } & \multicolumn{3}{|c|}{ Current Account } & \multicolumn{3}{|c|}{ Consumption } \\
\hline & $\begin{array}{l}\text { All } \\
(1)\end{array}$ & $\begin{array}{l}\text { Adv } \\
(2)\end{array}$ & $\begin{array}{c}\text { Dev } \\
(3)\end{array}$ & $\begin{array}{l}\text { All } \\
(4)\end{array}$ & $\begin{array}{l}\text { Adv } \\
\text { (5) }\end{array}$ & $\begin{array}{c}\text { Dev } \\
(6)\end{array}$ & $\begin{array}{l}\text { All } \\
(7)\end{array}$ & $\begin{array}{c}\text { Adv } \\
(8)\end{array}$ & $\begin{array}{l}\text { Dev } \\
(9)\end{array}$ \\
\hline On impact & $\begin{array}{c}3.63^{* * *} \\
(1.30)\end{array}$ & $\begin{array}{c}-2.76^{*} \\
(1.68)\end{array}$ & $\begin{array}{c}4.66^{* * *} \\
(1.55)\end{array}$ & $\begin{array}{c}-2.69^{* * * *} \\
(1.02)\end{array}$ & $\begin{array}{r}-2.06^{*} \\
(1.19)\end{array}$ & $\begin{array}{c}-2.77^{\text {*** }} \\
(1.17)\end{array}$ & $\begin{array}{c}2.35^{* *} \\
(1.06)\end{array}$ & $\begin{array}{c}-2.46 \\
(3.26)\end{array}$ & $\begin{array}{c}2.89^{* *} \\
(1.15)\end{array}$ \\
\hline 1 year & $\begin{array}{c}6.91^{* *} \\
(2.56)\end{array}$ & $\begin{array}{c}-3.92 \\
(2.82)\end{array}$ & $\begin{array}{c}8.59^{* *} \\
(3.06)\end{array}$ & $\begin{array}{c}-4.92^{* *} \\
(1.50)\end{array}$ & $\begin{array}{c}-6.35 \\
(4.18)\end{array}$ & $\begin{array}{c}-4.72^{* *} \\
(1.61)\end{array}$ & $\begin{array}{c}5.59^{* *} \\
(1.75)\end{array}$ & $\begin{array}{c}-0.98 \\
(1.94)\end{array}$ & $\begin{array}{l}6.65^{* * *} \\
(2.04)\end{array}$ \\
\hline 2 years & $\begin{array}{c}4.85^{*} \\
(2.48)\end{array}$ & $\begin{array}{r}-6.09^{*} \\
(3.67)\end{array}$ & $\begin{array}{c}6.69^{* *} \\
(2.95)\end{array}$ & $\begin{array}{r}-3.26^{*} \\
(1.80)\end{array}$ & $\begin{array}{c}-5.27 \\
(5.42)\end{array}$ & $\begin{array}{c}-2.96 \\
(1.90)\end{array}$ & $\begin{array}{c}5.61^{* *} \\
(2.41)\end{array}$ & $\begin{array}{c}-0.26 \\
(2.70)\end{array}$ & $\begin{array}{c}6.73^{* *} \\
(2.84)\end{array}$ \\
\hline 3 years & $\begin{array}{c}2.88 \\
(2.90)\end{array}$ & $\begin{array}{c}-10.71^{* *} \\
(5.06)\end{array}$ & $\begin{array}{c}5.06 \\
(3.30)\end{array}$ & $\begin{array}{c}-2.32 \\
(1.66)\end{array}$ & $\begin{array}{c}-3.83 \\
(3.89)\end{array}$ & $\begin{array}{c}-2.01 \\
(1.82)\end{array}$ & $\begin{array}{c}5.48^{*} \\
(2.99)\end{array}$ & $\begin{array}{c}-3.09 \\
(4.59)\end{array}$ & $\begin{array}{c}6.88^{* *} \\
(3.49)\end{array}$ \\
\hline First-stage $F$ & 30.7 & 18.5 & 23.5 & 32.5 & 31.3 & 24.5 & 32.6 & 19.9 & 25.6 \\
\hline Obs. & 2,354 & 643 & 1,711 & 2,408 & 629 & 1,779 & 2,447 & 644 & 1,803 \\
\hline
\end{tabular}

Notes: This table reports the response of the real exchange rate, current account-to-GDP ratio, and consumption (in percent) to an increase in $g$ of 1 percent of GDP when we control for financial crises. The $g$ shocks are constructed using military spending as an instrument for total government spending. 
Table C10. List of Excluded Commodity Exporters

\begin{tabular}{|c|c|c|c|}
\hline \multirow[b]{2}{*}{ Data source } & \multirow{2}{*}{$\begin{array}{c}\text { Share of oil, metals } \\
>15 \% \text { of GDP } \\
\text { UNCTAD } \\
\text { (1) }\end{array}$} & \multicolumn{2}{|c|}{$\begin{array}{l}\text { Share of all exported commodities } \\
<50 \% \text { of total exports }\end{array}$} \\
\hline & & $\begin{array}{l}\text { Comtrade } \\
\text { (2) }\end{array}$ & $\begin{array}{l}\text { UNCTAD } \\
\text { (3) }\end{array}$ \\
\hline Algeria & $\mathrm{XX}$ & & \\
\hline \multicolumn{4}{|l|}{ Argentina } \\
\hline \multicolumn{4}{|l|}{ Australia } \\
\hline \multicolumn{4}{|l|}{ Azerbaijan } \\
\hline \multicolumn{4}{|l|}{ Bahrain } \\
\hline \multicolumn{4}{|l|}{ Bolivia } \\
\hline \multicolumn{4}{|l|}{ Brunei } \\
\hline \multicolumn{4}{|l|}{ Burkina Faso } \\
\hline \multicolumn{4}{|l|}{ Burundi } \\
\hline \multicolumn{4}{|l|}{ Cameroon } \\
\hline Chad & & $\mathrm{X}$ & \\
\hline Chile & $\mathrm{XX}$ & & \\
\hline \multicolumn{4}{|l|}{ Colombia } \\
\hline \multicolumn{4}{|l|}{ Côte d'Ivoire } \\
\hline \multicolumn{4}{|l|}{ Ecuador } \\
\hline \multicolumn{4}{|l|}{ Ghana } \\
\hline \multicolumn{4}{|l|}{ Guyana } \\
\hline Indonesia & & & $\mathrm{O}$ \\
\hline \multicolumn{4}{|l|}{ Iran } \\
\hline \multicolumn{4}{|l|}{ Kazakhstan } \\
\hline \multicolumn{4}{|l|}{ Mali } \\
\hline Mauritania & $\mathrm{XX}$ & & \\
\hline \multicolumn{4}{|l|}{ Mongolia } \\
\hline \multicolumn{4}{|l|}{ Mozambique } \\
\hline Nicaragua & & & $\mathrm{O}$ \\
\hline Nigeria & $\mathrm{XX}$ & & \\
\hline \multicolumn{4}{|l|}{ Norway } \\
\hline Oman & $\mathrm{XX}$ & & \\
\hline \multicolumn{4}{|l|}{ Papua New Guinea } \\
\hline \multicolumn{4}{|l|}{ Paraguay } \\
\hline \multicolumn{4}{|l|}{ Peru } \\
\hline Russia & $\mathrm{XX}$ & & \\
\hline \multirow{2}{*}{\multicolumn{4}{|c|}{$\begin{array}{l}\text { Saudi Arabia } \\
\text { Syria }\end{array}$}} \\
\hline & & & \\
\hline United Arab Emirates & $\mathrm{XX}$ & $\mathrm{O}$ & \\
\hline Venezuela & & & \\
\hline Yemen & & & \\
\hline Zambia & $\mathrm{XX}$ & & \\
\hline
\end{tabular}

Notes: This table lists countries with a share of commodities in total exports above 50 percent in a median year, according to at least one of the two data sources considered. These countries are excluded from the estimation sample in the robustness exercise reported in Table 4. In column (1), XX denotes countries that, in addition, have oil and metals exports above 15 percent of GDP, according to the UNCTAD data. In contrast, X indicates that the country has a share of commodities below 50 percent of total exports in the U.N. Comtrade database (column 2) or the UNCTAD (column 3), while $\mathrm{O}$ indicates missing data in the corresponding database. Countries without X or $\mathrm{O}$ markings have a share of commodities above 50 percent of total exports. 
Table C11. Excluding Large Commodity Exporters

\begin{tabular}{|c|c|c|c|c|c|c|c|c|c|}
\hline & \multicolumn{3}{|c|}{ Real Exchange Rate } & \multicolumn{3}{|c|}{ Current Account } & \multicolumn{3}{|c|}{ Consumption } \\
\hline & $\begin{array}{l}\text { All } \\
(1)\end{array}$ & $\begin{array}{c}\text { Adv } \\
(2)\end{array}$ & $\begin{array}{c}\text { Dev } \\
(3)\end{array}$ & $\begin{array}{l}\text { All } \\
(4) \\
\end{array}$ & $\begin{array}{c}\text { Adv } \\
(5)\end{array}$ & $\begin{array}{c}\text { Dev } \\
(6)\end{array}$ & $\begin{array}{l}\text { All } \\
(7) \\
\end{array}$ & $\begin{array}{c}\text { Adv } \\
(8)\end{array}$ & $\begin{array}{c}\text { Dev } \\
(9) \\
\end{array}$ \\
\hline On impact & $\begin{array}{c}2.81^{* *} \\
(1.23)\end{array}$ & $\begin{array}{c}-3.88^{* *} \\
(1.93)\end{array}$ & $\begin{array}{l}3.68^{* * *} \\
(1.37)\end{array}$ & $\begin{array}{c}-2.15^{* * *} \\
(0.83)\end{array}$ & $\begin{array}{r}-2.43^{*} \\
(1.41)\end{array}$ & $\begin{array}{c}-2.12^{* *} \\
(0.91)\end{array}$ & $\begin{array}{c}2.19^{* *} \\
(0.98)\end{array}$ & $\begin{array}{c}-4.94^{* *} \\
(2.28)\end{array}$ & $\begin{array}{l}3.00^{* * *} \\
(1.05)\end{array}$ \\
\hline 1 year & $\begin{array}{l}7.10^{* *} \\
(2.61)\end{array}$ & $\begin{array}{r}-5.55^{*} \\
(3.16)\end{array}$ & $\begin{array}{c}8.75^{* *} \\
(3.01)\end{array}$ & $\begin{array}{c}-4.35^{* *} \\
(1.45)\end{array}$ & $\begin{array}{c}-6.34 \\
(5.15)\end{array}$ & $\begin{array}{c}-4.12^{* *} \\
(1.48)\end{array}$ & $\begin{array}{c}5.79^{* *} \\
(1.58)\end{array}$ & $\begin{array}{l}-1.50 \\
(2.54)\end{array}$ & $\begin{array}{c}6.71^{* * *} \\
(1.76)\end{array}$ \\
\hline 2 years & $\begin{array}{l}4.90^{* *} \\
(2.49)\end{array}$ & $\begin{array}{c}-8.26^{* *} \\
(4.10)\end{array}$ & $\begin{array}{c}6.70^{* *} \\
(2.84)\end{array}$ & $\begin{array}{c}-3.52^{* *} \\
(1.53)\end{array}$ & $\begin{array}{c}-6.57 \\
(6.50)\end{array}$ & $\begin{array}{c}-3.08^{* *} \\
(1.47)\end{array}$ & $\begin{array}{l}5.07^{* * *} \\
(1.96)\end{array}$ & $\begin{array}{c}-2.11 \\
(3.11)\end{array}$ & $\begin{array}{l}6.08^{* * *} \\
(2.17)\end{array}$ \\
\hline 3 years & $\begin{array}{c}3.28 \\
(3.00)\end{array}$ & $\begin{array}{c}-13.76^{* *} \\
(6.58)\end{array}$ & $\begin{array}{c}5.34 \\
(3.26)\end{array}$ & $\begin{array}{r}-2.63^{*} \\
(1.56)\end{array}$ & $\begin{array}{c}-5.45 \\
(5.16)\end{array}$ & $\begin{array}{c}-2.15 \\
(1.60)\end{array}$ & $\begin{array}{c}3.13 \\
(2.62)\end{array}$ & $\begin{array}{c}-8.79^{* *} \\
(3.77)\end{array}$ & $\begin{array}{c}4.51 \\
(2.88)\end{array}$ \\
\hline $\begin{array}{l}\text { First-stage } F \\
\text { Obs. }\end{array}$ & $\begin{array}{c}33.5 \\
2,234\end{array}$ & $\begin{array}{l}13.8 \\
631\end{array}$ & $\begin{array}{c}26.8 \\
1,603\end{array}$ & $\begin{array}{c}37.1 \\
2,283\end{array}$ & $\begin{array}{l}23.9 \\
617\end{array}$ & $\begin{array}{c}29.1 \\
1,666\end{array}$ & $\begin{array}{c}37.8 \\
2,331\end{array}$ & $\begin{array}{l}17.3 \\
634\end{array}$ & $\begin{array}{l}30.9 \\
1,697\end{array}$ \\
\hline
\end{tabular}

Notes: This table reports robustness of the results to the exclusion of countries with oil and metals exports above 15 percent of GDP, according to the UNCTAD data. The excluded countries are marked by XX in Table C10.

Table C12. Robustness to Excluding Large Arms Importers: Alternative Cutoff (70 percent)

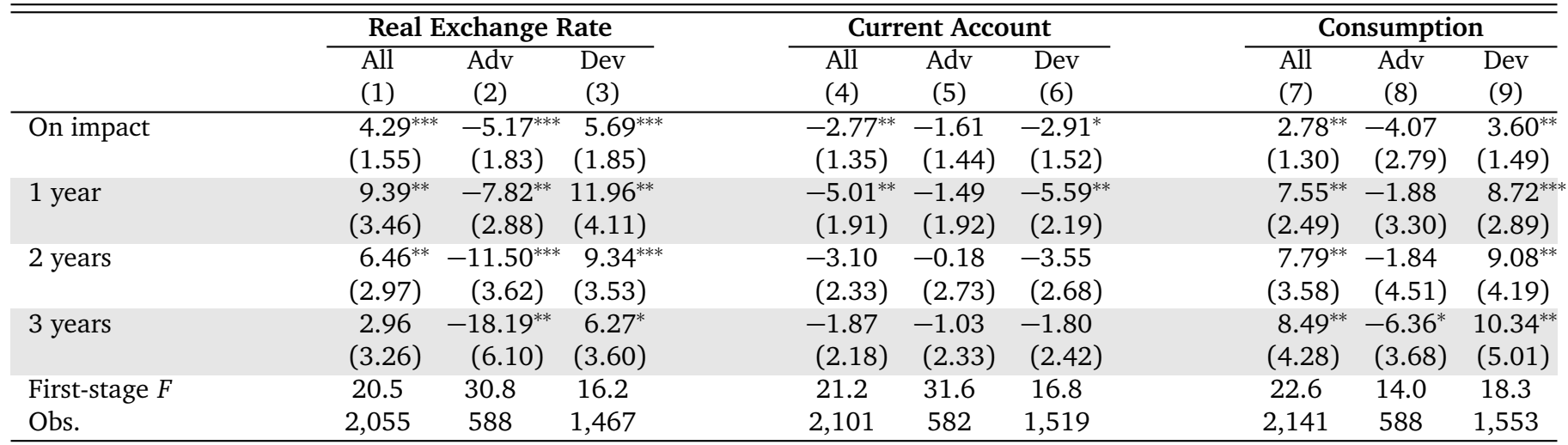

Notes: This table reports the response of the real exchange rate, current account-to-GDP ratio, and consumption (in percent) to an increase in $g$ of 1 percent of GDP. We estimate the baseline specification for the sample of countries excluding countries that have at least one year with military spending over 70 percent on arms imports. These countries are Bahrain, Brunei, Cape Verde, Djibouti, Egypt, El Salvador, Georgia, Guyana, Kyrgyzstan, Laos, Luxembourg, Mauritius, Mongolia, the Seychelles, the United Arab Emirates, Uganda, and Venezuela.

Table C13. Excluding Foreign-Aid Recipients

\begin{tabular}{|c|c|c|c|c|c|c|c|c|c|}
\hline & \multicolumn{3}{|c|}{ Real Exchange Rate } & \multicolumn{3}{|c|}{ Current Account } & \multicolumn{3}{|c|}{ Consumption } \\
\hline & $\begin{array}{l}\text { All } \\
(1)\end{array}$ & $\begin{array}{l}\text { Adv } \\
(2)\end{array}$ & $\begin{array}{c}\text { Dev } \\
(3)\end{array}$ & $\begin{array}{l}\text { All } \\
(4)\end{array}$ & $\begin{array}{l}\text { Adv } \\
(5)\end{array}$ & $\begin{array}{c}\text { Dev } \\
(6)\end{array}$ & $\begin{array}{l}\text { All } \\
(7)\end{array}$ & $\begin{array}{l}\text { Adv } \\
(8)\end{array}$ & $\begin{array}{l}\text { Dev } \\
(9)\end{array}$ \\
\hline On impact & $\begin{array}{c}3.91^{* * *} \\
(1.49)\end{array}$ & $\begin{array}{r}-3.00^{*} \\
(1.71)\end{array}$ & $\begin{array}{c}5.30^{* * *} \\
(1.81)\end{array}$ & $\begin{array}{c}-3.49^{* * *} \\
(1.32)\end{array}$ & $\begin{array}{r}-2.04^{*} \\
(1.17)\end{array}$ & $\begin{array}{c}-3.78^{* *} \\
(1.61)\end{array}$ & $\begin{array}{c}1.93 \\
(1.28)\end{array}$ & $\begin{array}{c}-2.60 \\
(3.19)\end{array}$ & $\begin{array}{c}2.64^{*} \\
(1.42)\end{array}$ \\
\hline 1 year & $\begin{array}{c}7.21^{* *} \\
(3.08)\end{array}$ & $\begin{array}{c}-4.18 \\
(2.85)\end{array}$ & $\begin{array}{c}9.70^{* *} \\
(3.83)\end{array}$ & $\begin{array}{c}-6.13^{* *} \\
(1.79)\end{array}$ & $\begin{array}{c}-6.18 \\
(4.13)\end{array}$ & $\begin{array}{c}-6.13^{* *} \\
(1.98)\end{array}$ & $\begin{array}{c}5.70^{* *} \\
(2.23)\end{array}$ & $\begin{array}{c}-1.33 \\
(1.94)\end{array}$ & $\begin{array}{l}7.37^{* * *} \\
(2.78)\end{array}$ \\
\hline 2 years & $\begin{array}{c}4.43 \\
(3.02)\end{array}$ & $\begin{array}{r}-6.17^{*} \\
(3.69)\end{array}$ & $\begin{array}{c}6.89^{*} \\
(3.73)\end{array}$ & $\begin{array}{c}-3.77 \\
(2.30)\end{array}$ & $\begin{array}{c}-5.06 \\
(5.38)\end{array}$ & $\begin{array}{c}-3.47 \\
(2.53)\end{array}$ & $\begin{array}{c}6.65^{* *} \\
(3.21)\end{array}$ & $\begin{array}{c}-0.75 \\
(2.68)\end{array}$ & $\begin{array}{c}8.62^{* *} \\
(4.09)\end{array}$ \\
\hline 3 years & $\begin{array}{c}1.83 \\
(3.51)\end{array}$ & $\begin{array}{c}-10.73^{* *} \\
(5.11)\end{array}$ & $\begin{array}{c}4.67 \\
(4.10)\end{array}$ & $\begin{array}{c}-3.21^{*} \\
(1.86)\end{array}$ & $\begin{array}{c}-3.60 \\
(3.87)\end{array}$ & $\begin{array}{c}-3.02 \\
(2.09)\end{array}$ & $\begin{array}{l}7.55^{* *} \\
(3.84)\end{array}$ & $\begin{array}{c}-3.70 \\
(4.68)\end{array}$ & $\begin{array}{l}10.04^{* *} \\
(4.78)\end{array}$ \\
\hline First-stage $F$ & 22.1 & 19.1 & 15.8 & 23.5 & 32.3 & 16.5 & 23.5 & 20.6 & 17.2 \\
\hline Obs. & 1,994 & 643 & 1,351 & 2,036 & 629 & 1,407 & 2,070 & 644 & 1,426 \\
\hline
\end{tabular}

Notes: This table reports the response of the real exchange rate, current account-to-GDP ratio, and consumption (in percent) to an increase in $g$ of 1 percent of GDP. The $g$ shocks are constructed using military spending as an instrument for total government spending. We estimate the baseline specification dropping the countries identified as foreign-aid recipients by Kraay (2012, table 1). The results are similar to other specifications. 
Table C14. Controlling for Global Military Spending

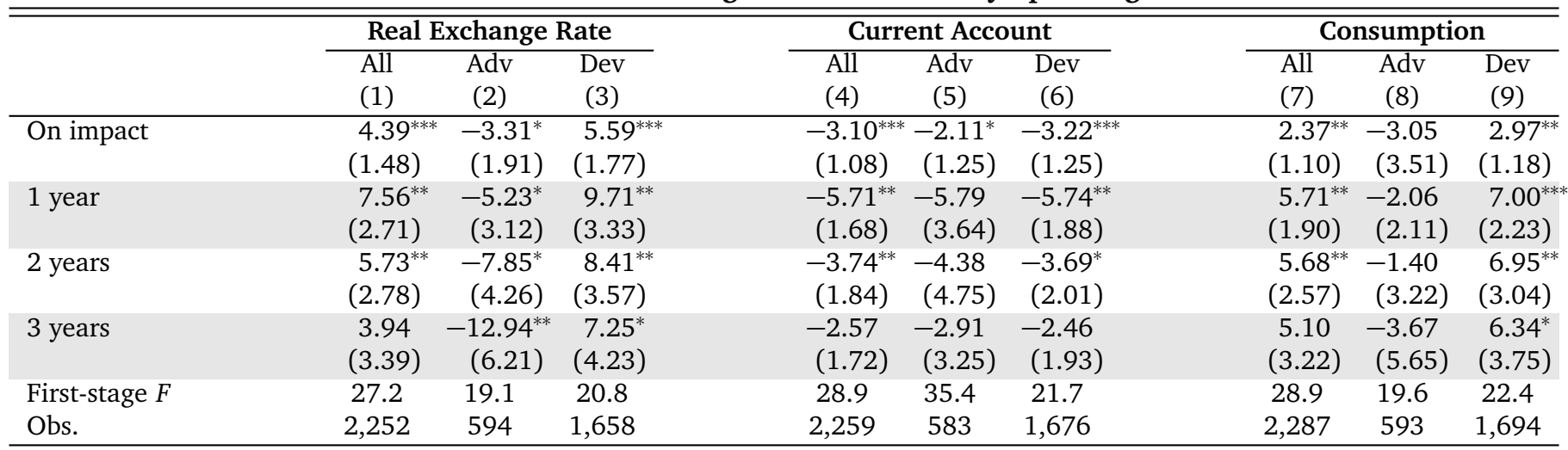

Notes: This table reports the response of the real exchange rate, current account-to-GDP ratio, and consumption (in percent) to an increase in $g$ of 1 percent of GDP. The $g$ shocks are constructed using military spending as an instrument for total government spending. We estimate the baseline specification with an additional control for global military spending. The results are similar to other specifications.

Table C15. 1989-2007 Subsample

\begin{tabular}{|c|c|c|c|c|c|c|c|c|c|}
\hline & \multicolumn{3}{|c|}{ Real Exchange Rate } & \multicolumn{3}{|c|}{ Current Account } & \multicolumn{3}{|c|}{ Consumption } \\
\hline & All & $\mathrm{Adv}$ & Dev & All & Adv & Dev & All & Adv & Dev \\
\hline & (1) & $(2)$ & $(3)$ & (4) & $(5)$ & $(6)$ & (7) & $(8)$ & $(9)$ \\
\hline On impact & $3.95^{\text {** }}$ & $-5.60^{* *}$ & $5.27^{* *}$ & $-2.94^{* *}$ & -0.99 & $-3.17^{* *}$ & $2.48^{*}$ & -5.03 & $3.37^{* *}$ \\
\hline \multirow[t]{2}{*}{1 year } & $8.44^{* *}$ & $-7.98^{*}$ & $10.75^{* *}$ & $-5.37^{* *}$ & -8.60 & $-4.81^{* *}$ & $7.13^{* *}$ & -1.82 & $8.32^{* * *}$ \\
\hline & $(4.00)$ & $(4.14)$ & $(4.72)$ & (2.07) & $(9.24)$ & $(1.98)$ & $(2.59)$ & $(4.37)$ & $(2.94)$ \\
\hline 2 years & 4.87 & $-9.50^{*}$ & $7.00^{*}$ & -2.81 & -7.01 & -2.11 & $6.29^{* *}$ & -2.58 & $7.54^{* *}$ \\
\hline \multirow[t]{2}{*}{3 years } & 2.94 & $-14.92^{* *}$ & 5.61 & -1.35 & -4.64 & -0.78 & 4.65 & -4.86 & 5.85 \\
\hline & (3.74) & (5.55) & $(4.33)$ & (1.92) & $(4.76)$ & $(2.12)$ & (3.53) & $(7.41)$ & $(3.98)$ \\
\hline First-stage $F$ & 15.3 & 4.3 & 12.1 & 16.7 & 6.4 & 13.0 & 18.9 & 5.7 & 15.6 \\
\hline Obs. & 1,671 & 470 & 1,201 & 1,747 & 456 & 1,291 & 1,779 & 473 & 1,306 \\
\hline
\end{tabular}

Notes: This table reports the responses of the real exchange rate, current account-to-GDP ratio, and consumption (in percent) to an increase in $g$ of 1 percent of GDP. The $g$ shocks are constructed using military spending as an instrument for total government spending. We estimate the baseline specification for the sample between 1989 and 2007. The results are similar to those from other specifications.

Table C16. Public Investment

\begin{tabular}{|c|c|c|c|c|c|c|c|c|c|}
\hline & \multicolumn{3}{|c|}{ Real Exchange Rate } & \multicolumn{3}{|c|}{ Current Account } & \multicolumn{3}{|c|}{ Consumption } \\
\hline & $\begin{array}{l}\text { All } \\
(1)\end{array}$ & $\begin{array}{c}\text { Adv } \\
(2)\end{array}$ & $\begin{array}{l}\text { Dev } \\
(3)\end{array}$ & $\begin{array}{l}\text { All } \\
(4)\end{array}$ & $\begin{array}{c}\text { Adv } \\
(5)\end{array}$ & $\begin{array}{c}\text { Dev } \\
(6)\end{array}$ & $\begin{array}{l}\text { All } \\
\text { (7) }\end{array}$ & $\begin{array}{c}\text { Adv } \\
(8)\end{array}$ & $\begin{array}{l}\text { Dev } \\
(9)\end{array}$ \\
\hline On impact & $\begin{array}{c}-0.08 \\
(0.07)\end{array}$ & $\begin{array}{c}-0.20^{\text {*** }} \\
(0.10)\end{array}$ & $\begin{array}{c}0.05 \\
(0.15)\end{array}$ & $\begin{array}{c}-0.15^{\text {*** }} \\
(0.06)\end{array}$ & $\begin{array}{r}-0.14^{*} \\
(0.08)\end{array}$ & $\begin{array}{c}-0.18^{* *} \\
(0.08)\end{array}$ & $\begin{array}{c}0.15^{\text {** }} \\
(0.07)\end{array}$ & $\begin{array}{c}0.03 \\
(0.08)\end{array}$ & $\begin{array}{c}0.29^{\text {**** }} \\
(0.11)\end{array}$ \\
\hline 1 year & $\begin{array}{c}-0.06 \\
(0.14)\end{array}$ & $\begin{array}{c}-0.35^{* *} \\
(0.17)\end{array}$ & $\begin{array}{c}0.22 \\
(0.30)\end{array}$ & $\begin{array}{c}-0.25^{* *} \\
(0.09)\end{array}$ & $\begin{array}{c}-0.12 \\
(0.10)\end{array}$ & $\begin{array}{c}-0.37^{* *} \\
(0.12)\end{array}$ & $\begin{array}{c}0.35^{* *} \\
(0.10)\end{array}$ & $\begin{array}{c}0.17 \\
(0.11)\end{array}$ & $\begin{array}{c}0.51^{* * *} \\
(0.16)\end{array}$ \\
\hline 2 years & $\begin{array}{c}-0.11 \\
(0.15)\end{array}$ & $\begin{array}{c}-0.47^{* *} \\
(0.22)\end{array}$ & $\begin{array}{c}0.28 \\
(0.34)\end{array}$ & $\begin{array}{c}-0.24^{* * *} \\
(0.08)\end{array}$ & $\begin{array}{r}-0.15 \\
(0.09)\end{array}$ & $\begin{array}{c}-0.34^{* * *} \\
(0.13)\end{array}$ & $\begin{array}{c}0.40^{* * *} \\
(0.15)\end{array}$ & $\begin{array}{c}0.13 \\
(0.16)\end{array}$ & $\begin{array}{c}0.69^{* * *} \\
(0.24)\end{array}$ \\
\hline 3 years & $\begin{array}{c}-0.08 \\
(0.23)\end{array}$ & $\begin{array}{r}-0.66^{*} \\
(0.37)\end{array}$ & $\begin{array}{c}0.42 \\
(0.47)\end{array}$ & $\begin{array}{c}-0.19^{* *} \\
(0.07)\end{array}$ & $\begin{array}{r}-0.10 \\
(0.11)\end{array}$ & $\begin{array}{c}-0.27^{* *} \\
(0.11)\end{array}$ & $\begin{array}{c}0.42^{\text {** }} \\
(0.18)\end{array}$ & $\begin{array}{c}0.02 \\
(0.19)\end{array}$ & $\begin{array}{c}0.81^{\text {*** }} \\
(0.27)\end{array}$ \\
\hline First-stage $F$ & 10.7 & 8.5 & 4.6 & 10.5 & 7.6 & 6.0 & 11.5 & 7.4 & 5.7 \\
\hline Obs. & 621 & 415 & 206 & 617 & 415 & 202 & 619 & 415 & 204 \\
\hline
\end{tabular}

Notes: This table reports the responses of the real exchange rate, current account-to-GDP ratio, and consumption (in percent) to a 1 percent increase in public investment. The public investment shocks are instrumented using military spending. Specifically, our estimation is as follows:

$$
\frac{x_{i, t+h}-x_{i, t-1}}{x_{i, t-1}}=c+\alpha_{i}+\beta_{h} \frac{\Delta g_{i t}^{I}}{g_{i, t-1}^{I}}+\Phi^{x}(L) \frac{\Delta x_{i, t-1}}{x_{i, t-2}}+\Phi^{g}(L) \frac{\Delta g_{i, t-1}}{y_{i, t-2}}+\boldsymbol{\gamma}^{\prime} \boldsymbol{z}_{i t}+\varepsilon_{i t}, \text { for } h=0,1,2, \ldots,
$$

where we instrument $\frac{\Delta g_{i t}^{I}}{g_{i, t-1}^{I}}$ by changes in military spending. 
Table C17. The Responses of Tax Rates, Government Debt, and Inflation

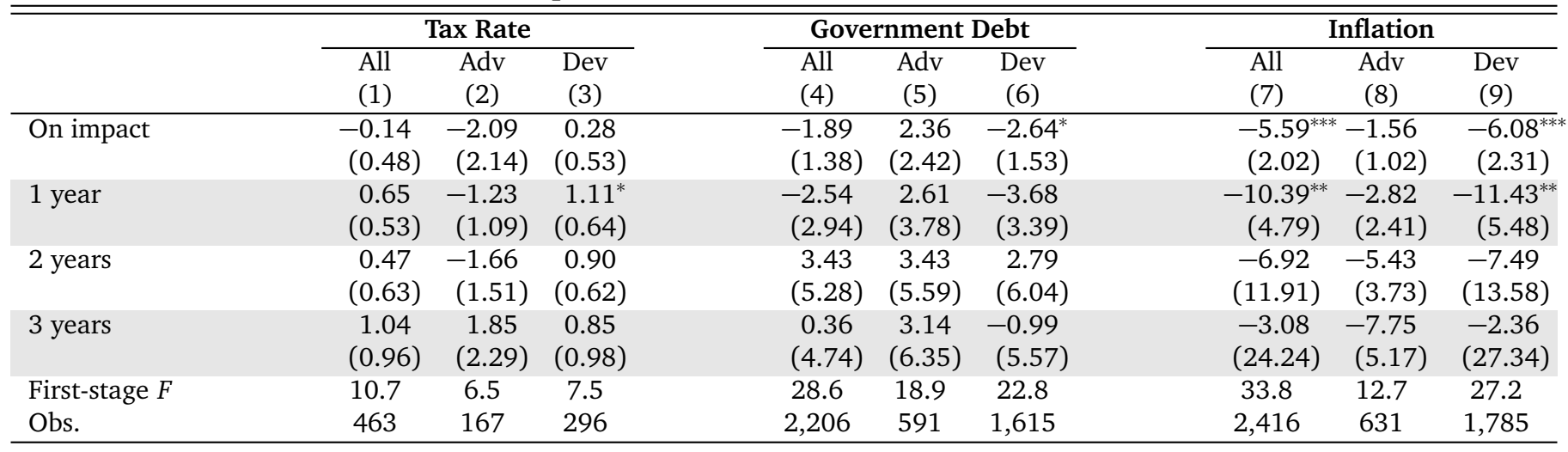

Notes: This table reports the response of top marginal tax rate, government debt-to-GDP ratio, and inflation to an increase in $g$ of 1 percent of GDP. The $g$ shocks are constructed using military spending as an instrument for total government spending. We estimate the baseline specification for the sample between 1989 and 2007. The results are similar to the results with other specifications.

Table C18. Local Projections with Blanchard-Perotti Identification

\begin{tabular}{|c|c|c|c|c|c|c|c|c|c|}
\hline & \multicolumn{3}{|c|}{ Real Exchange Rate } & \multicolumn{3}{|c|}{ Current Account } & \multicolumn{3}{|c|}{ Consumption } \\
\hline & All & Adv & Dev & All & Adv & Dev & All & Adv & Dev \\
\hline & (1) & $(2)$ & (3) & (4) & $(5)$ & (6) & (7) & $(8)$ & (9) \\
\hline On impact & $0.45^{* *}$ & $1.42^{* * *}$ & 0.32 & $-0.36^{* * *}$ & $-1.23^{* * *}$ & $-0.24^{*}$ & $0.45^{\text {** }}$ & $1.26^{* * * *}$ & 0.32 \\
\hline \multirow[t]{2}{*}{1 year } & 0.35 & $2.53^{* *}$ & 0.08 & $-0.76^{* *}$ & $-1.42^{* *}$ & $-0.67^{* *}$ & $0.98^{* *}$ & $2.57^{* *}$ & $0.76^{* *}$ \\
\hline & $(0.43)$ & $(0.81)$ & $(0.48)$ & $(0.22)$ & $(0.37)$ & $(0.24)$ & $(0.30)$ & $(0.60)$ & $(0.32)$ \\
\hline 2 years & 0.11 & $2.10^{* *}$ & -0.14 & $-0.54^{* *}$ & $-1.26^{* * *}$ & $-0.46^{*}$ & $0.85^{* *}$ & $2.23^{* *}$ & 0.67 \\
\hline \multirow[t]{2}{*}{3 years } & 0.06 & $1.62^{*}$ & -0.12 & -0.41 & $-0.62^{*}$ & -0.39 & $1.04^{* *}$ & 1.54 & $0.98^{*}$ \\
\hline & $(0.65)$ & $(0.84)$ & $(0.73)$ & $(0.25)$ & $(0.32)$ & $(0.28)$ & $(0.47)$ & $(0.92)$ & $(0.52)$ \\
\hline Obs. & 2,387 & 798 & 1,589 & 2,445 & 795 & 1,650 & 2,488 & 807 & 1,681 \\
\hline
\end{tabular}

Notes: This table reports the response of the REER, consumption, current account-to-output ratio to an increase in the $g$ shock of 1 percent of GDP, identified by the timing assumption. "Adv" denotes the advanced-countries sample, "Dev" denotes the developing-countries sample. More specifically, the estimation specification based on the Jordà (2005) method is as follows:

$$
\frac{x_{i, t+h}-x_{i, t-1}}{x_{i, t-1}}=c+\alpha_{i}+\beta_{h} \frac{\Delta g_{i t}}{y_{i, t-1}}+\Phi^{x}(L) \frac{\Delta x_{i, t-1}}{x_{i, t-2}}+\Phi^{g}(L) \frac{\Delta g_{i, t-1}}{y_{i, t-2}}+\boldsymbol{\gamma}^{\prime} \boldsymbol{z}_{i t}+\varepsilon_{i t}, \text { for } h=0,1,2, \ldots,
$$

which estimates the response of variable $x$ at horizon $h$ to the government spending changes that are orthogonal to all information available at time $t$. This specification is similar to ordering government spending first in a structural VAR. 


\section{Model}

This section describes the standard model in the main text.

\section{D.1 The Standard Model: Complete Markets}

There are two countries, home and foreign of the size $A$ and $A^{*}$, respectively. Households in the home country maximize the following objective function:

$$
E_{0} \sum_{t=0}^{\infty} \beta^{t} U\left(C_{t}, L_{t}\right)
$$

where $\beta$ is a discount factor, $C_{t}$ denotes consumption of a composite good and $L_{t}$ is the labor supply. The standard model has the following functional form for the utility function:

$$
U(C, L)=\frac{C^{1-\sigma}-1}{1-\sigma}-\phi_{L} \frac{L^{1+\frac{1}{v}}}{1+\frac{1}{v}}
$$

Households in each country have access to complete financial markets. Thus, they face a period-by-period budget constraint as follows:

$$
C_{t}+E_{t} r_{t, t+1} \frac{B_{D, t+1}}{P_{t}}+E_{t} r_{t, t+1}^{*} \frac{Q_{t} B_{F, t+1}}{P_{t}} \leq W_{t} L_{t}+\frac{B_{D, t}}{P_{t}}+\frac{Q_{t} B_{F, t}}{P_{t}}-T_{t}+\Pi_{t}
$$

where $B_{F, t}$ is a nominal bond in the foreign currency, $Q_{t}$ is the nominal exchange rate (home currency per unit of foreign currency) $T_{t}$ is lump sum tax, and $\Pi_{t}$ is profits. Then, the real exchange rate $q_{t}$ is defined as:

$$
q_{t}=\frac{P_{t}}{Q_{t} P_{t}^{*}}
$$

Aggregate consumption $C_{t}$ is an Armington aggregator of the home $\left(C_{D, t}\right)$ and foreign $\left(C_{F, t}\right)$ consumption goods, with the elasticity of substitution between home and foreign goods $\gamma$ :

$$
C_{t}=\left[\left(\omega_{C}\right)^{\frac{1}{\gamma}}\left(C_{D, t}\right)^{\frac{\gamma-1}{\gamma}}+\left(1-\omega_{C}\right)^{\frac{1}{\gamma}}\left(C_{F, t}\right)^{\frac{\gamma-1}{\gamma}}\right]^{\frac{\gamma}{\gamma-1}} \text {, }
$$

where $\omega_{C}$ is a home bias parameter. The corresponding demand functions and the price level $\left(P_{t}\right)$ are given by:

$$
\begin{gathered}
C_{D, t}=\omega_{C}\left(\frac{P_{D, t}}{P_{t}}\right)^{-\gamma} C_{t}, \quad C_{F, t}=\left(1-\omega_{C}\right)\left(\frac{P_{F, t}}{P_{t}}\right)^{-\gamma} C_{t}, \\
P_{t}=\left[\omega_{C} P_{D, t}^{1-\gamma}+\left(1-\omega_{C}\right) P_{F, t}^{1-\gamma}\right]^{\frac{1}{1-\gamma}} .
\end{gathered}
$$

Final goods $C_{D, t}$ and $C_{F, t}$ are CES indices of the differentiated goods produced in the two countries, given by:

$$
C_{D, t}=\left[\int C_{D, t}(z)^{\frac{\varepsilon-1}{\varepsilon}} d z\right]^{\frac{\varepsilon}{\varepsilon-1}}, \quad C_{F, t}=\left[\int C_{F, t}(z)^{\frac{\varepsilon-1}{\varepsilon}} d z\right]^{\frac{\varepsilon}{\varepsilon-1}},
$$

where $\varepsilon$ is the elasticity of substitution between differentiated goods and $z$ is an index of the industry where 
firms change prices at the same time.

Each country has a government, financing its spending by lump-sum taxes. There is an independent central bank in each country. The central banks conduct monetary policy by controlling the short-term nominal interest rate in the domestic currency.

Government spending $G_{t}$ is also a composite of home and foreign goods:

$$
G_{t}=\left[\left(\omega_{G}\right)^{\frac{1}{\gamma}}\left(G_{D, t}\right)^{\frac{\gamma-1}{\gamma}}+\left(1-\omega_{G}\right)^{\frac{1}{\gamma}}\left(G_{F, t}\right)^{\frac{\gamma-1}{\gamma}}\right]^{\frac{\gamma}{\gamma-1}},
$$

and

$$
G_{D, t}=\left[\int G_{D, t}(z)^{\frac{\varepsilon-1}{\varepsilon}} d z\right]^{\frac{\varepsilon}{\varepsilon-1}}, \quad G_{F, t}=\left[\int G_{F, t}(z)^{\frac{\varepsilon-1}{\varepsilon}} d z\right]^{\frac{\varepsilon}{\varepsilon-1}} .
$$

Government spending follows an exogenous process:

$$
\ln G_{t}=\left(1-\rho_{G}\right) \ln G+\rho_{G} \ln G_{t-1}+\varepsilon_{G, t},
$$

where $\rho_{G}$ is an $\operatorname{AR}(1)$ coefficient and $\varepsilon \sim N\left(0, \sigma_{G}\right)$.

The intermediate good firms in industry $z$ have the following production function:

$$
Y_{t}(z)=f\left(L_{t}(z)\right)=A L_{t}(z)^{\alpha}
$$

where $A$ is a technology paramer. We assume no pricing to markets in the baseline model. Therefore, intermediate goods firm in industry $z$ maximizes the following objective function:

$$
E_{0} \sum_{t=0}^{\infty} r_{0, t} \theta^{t}\left[P_{D, t}(z) Y_{t}(z)-P_{t} W_{t} L_{t}(z)\right]
$$

subject to the production function, and the demand of home and foreign countries for their goods:

$$
\begin{gathered}
Y_{t}(z)=f\left(L_{t}(z)\right) \\
Y_{t}(z)=\left(\frac{P_{D, t}(z)}{P_{D, t}}\right)^{-\varepsilon} C_{D, t}+\left(\frac{P_{F, t}^{*}(z)}{P_{F, t}^{*}}\right)^{-\varepsilon} C_{F, t}^{*}+\left(\frac{P_{D, t}(z)}{P_{D, t}}\right)^{-\varepsilon} G_{D, t}+\left(\frac{P_{F, t}^{*}(z)}{P_{F, t}^{*}}\right)^{-\varepsilon} G_{F, t}^{*}
\end{gathered}
$$

where $\theta$ is the probability that the firms cannot change the prices.

Finally, the central bank in each country follows a Taylor rule as follows:

$$
\ln R_{t}=\rho_{R} R_{t-1}+\left(1-\rho_{R}\right)\left(\ln R+\phi_{\pi} \ln \left(\frac{\pi_{t}}{\pi}\right)\right)
$$

where the symbols without time subscript $(R, \pi)$ are the corresponding steady states.

\section{D.2 Incomplete Markets Model}

Households have access only to a one-period noncontingent bond. The budget constraint becomes,

$$
C_{t}+\frac{1}{R_{t}} \frac{B_{D, t+1}}{P_{t}}+\frac{1}{R_{t}^{*}} \frac{Q_{t} B_{F, t+1}}{P_{t}}=W_{t} L_{t}+\frac{B_{D, t}}{P_{t}}+\frac{Q_{t} B_{F, t}}{P_{t}}-T_{t}+\Pi_{t} .
$$

To maintain stationarity in the model, we follow Bodenstein (2011) and use the following Uzawa (1968) 
preferences:

$$
E_{0} \sum_{t=0}^{\infty} \beta_{t} U\left(C_{t}, L_{t}\right)
$$

where

$$
\begin{aligned}
\beta_{0} & =1 \\
\beta_{t+1} & =\beta \times f\left(U\left(C_{t}, L_{t}\right)\right) \beta_{t} .
\end{aligned}
$$

The general functional form of $f\left(U\left(C_{t}, L_{t}\right)\right)$ is as follows:

$$
f\left(U\left(C_{t}, L_{t}\right)\right)=1-\phi_{\beta}\left[\exp \left(U_{t}\right)-\exp \left(U_{s s}\right)\right]
$$

These preferences guarantee a locally unique steady-state, independent of initial conditions. ${ }^{1}$ The parameter $\phi_{\beta}$ determines how strongly the discount factor responds to consumption and leisure, and it is often assumed to be small in order to ensure stationarity.

The risk-sharing condition becomes,

$$
\frac{U_{c, t}}{U_{c, t}^{*}} q_{t}=\frac{f\left(U\left(C_{t}, L_{t}\right)\right)}{f\left(U\left(C_{t}^{*}, L_{t}^{*}\right)\right)} \frac{E_{t}\left(U_{c, t+1} q_{t+1}\right)}{E_{t}\left(U_{c, t+1}^{*}\right)} .
$$

Also, notice that the first-order condition for a foreign-bond holding is given by,

$$
U_{c, t} q_{t}=\beta\left[R_{t}^{*} f\left(U\left(C_{t}, L_{t}\right)\right)\right] E_{t}\left(U_{c, t+1} q_{t+1} \frac{1}{\pi_{t+1}^{*}}\right) .
$$

Thus, $f\left(U\left(C_{t}, L_{t}\right)\right)$ works like a borrowing premium in the sense that an increase in $C_{t}$ is associated with an increase in $f\left(U\left(C_{t}, L_{t}\right)\right)$, which is multiplied by nominal interest rate $R_{t}^{*}$.

\section{D.3 Consumption-Hours Complementarity}

Generally, under log linearization, it is sufficient to calibrate the parameters related to the preferences with complementarity as follows (see Bilbiie 2011):

$$
\begin{aligned}
\tilde{\sigma} & =-\frac{U_{C C} C}{U_{C}}, \\
\omega & =\frac{U_{C L} C}{U_{L}}-\frac{U_{C C} C}{U_{C}}, \\
\frac{1}{\tilde{v}} & =\frac{U_{L L} L}{U_{L}}-\frac{\left(U_{C L}\right)^{2} L}{U_{L} U_{C C}},
\end{aligned}
$$

where $\widetilde{\sigma}$ is the inverse of the elasticity of intertemporal substitution, $\omega$ is a measure of wealth effect on labor supply, and $\widetilde{v}$ is the Frisch elasticity of labor supply. The values of these parameters imply the degree of complementarity between consumption and hours worked defined as,

$$
\psi=\frac{U_{C L} L}{U_{C}}
$$

\footnotetext{
${ }^{1}$ Bodenstein (2011) suggests that other forms of adjustment, such as bond adjustment or risk premium, may have a uniqueness issue.
} 
where $\psi$ is positive with complementarity. (This complementarity can be stronger if the substitutability of home and market goods is stronger and the size of the home-production sector is larger; see Gnocchi, Hauser, and Pappa 2016.) We note that this complementarity is related to the risk-sharing condition obtained from log-linearization as follows:

$$
-\widetilde{\sigma} C_{t}+\widetilde{\sigma}^{*} C_{t}^{*}+\psi L_{t}-\psi^{*} L_{t}^{*}=q_{t} .
$$

Given the relatively small size of the home country, $-\tilde{\sigma} C_{t}+\psi L_{t} \simeq q_{t}$, and therefore complementarity $(\psi>0)$ together with an increase in labor inputs can lead to appreciation even if consumption increases.

\section{D.4 Rule-of-Thumb Consumers}

We follow Galí, López-Salido, and Vallés (2007) and assume that there are two types of households: a fraction $\lambda$ of households have access to financial markets while other households do not. The budget constraint for the households with asset-markets access is given by,

$$
\begin{aligned}
& C_{A, t}+E_{t} r_{t, t+1} \frac{B_{D, t+1}}{P_{t}}+E_{t} r_{t, t+1}^{*} \frac{Q_{t} B_{F, t+1}}{P_{t}} \\
\leq & W_{t} L_{t}+\frac{B_{D, t}}{P_{t}}+\frac{Q_{t} B_{F, t}}{P_{t}}-T_{A, t}+\Pi_{A, t},
\end{aligned}
$$

where the subscript $A$ denotes the allocation for those with access to financial markets. Households that do not have access to financial markets consume their after-tax income:

$$
C_{N, t}=W_{t} L_{N, t}-T_{N, t}+\Pi_{N, t}
$$

For simplicity, we assume $\Pi_{N, t}=0$. Then, we have $\Pi_{t}=\lambda \Pi_{A, t}$.

Then, the market clearing conditions for consumption and labor supply are given by,

$$
\begin{aligned}
& C_{t}=\lambda C_{A, t}+(1-\lambda) C_{N, t} \\
& L_{t}=\lambda L_{A, t}+(1-\lambda) L_{N, t}
\end{aligned}
$$

where $C_{A}$ denotes consumption by households with asset-markets access and $C_{N}$ denotes consumption by households without asset-markets access. We use the same functional form for utility as in the standard model. The fiscal rule and the budget constraint for a government debt $D_{t}$ and transfer $T_{t}$ are given by,

$$
\begin{aligned}
P_{t} T_{t}+\frac{1}{R_{t}} D_{t+1} & \geq D_{t}+P_{t}^{G} G_{t}, \\
P_{t} T_{t} & =\xi \pi_{t} D_{t} .
\end{aligned}
$$

Therefore,

$$
\begin{aligned}
T_{t}+\frac{1}{R_{t}} \frac{D_{t+1}}{P_{t}} & \geq \frac{D_{t}}{P_{t}}+\frac{P_{t}^{G}}{P_{t}} G_{t}, \\
T_{t} & =\xi \frac{D_{t}}{P_{t-1}}, \\
T_{t} & =\lambda T_{A, t}+(1-\lambda) T_{N, t} .
\end{aligned}
$$

For the allocation of transfers, we assume that,

$$
\frac{T_{A, t}}{T_{N, t}}=\text { const } .
$$




\section{D.5 Calibration}

The calibrated parameters for the models are presented in Table D19. Most of the values are standard in the international business cycle literature, such as Backus, Kehoe, and Kydland (1992), Chari, Kehoe, and McGrattan (2002), Steinsson (2008), and Garcia-Cicco, Pancrazi, and Uribe (2010).

Table D19. Calibrated Parameters

\begin{tabular}{lll}
\hline Parameter & & Value \\
\hline$\beta$ & Discount factor & 0.99 \\
$1 / \sigma$ & Elasticity of intertemporal substitution & $1 / 2$ \\
$\varepsilon$ & Elasticity of demand & 10 \\
$\alpha$ & Labor share & $2 / 3$ \\
$\nu$ & Frisch elasticity of labor supply & 1.6 \\
$\gamma$ & Elasticity of substitution between home and foreign goods & 0.75 and 1.5 \\
$1-\theta$ & Probability of price adjustment & 0.75 \\
$\omega_{C}, \omega_{G}$ & Home bias parameters & 0.85 \\
$\rho_{R}$ & Taylor Rule parameter for interest rate & 0.75 \\
$\phi_{\pi}$ & Taylor Rule parameter for inflation & 1.5 \\
$A$ & Relative size of home vs. foreign country & $1 / 20$ \\
$\rho_{G}$ & Persistence of government spending process & 0.975 \\
$L_{s s}$ & Steady-state hours & $1 / 3$ \\
$\frac{G}{Y}$ & Steady-state government spending shares & 0.16 \\
$\phi_{\beta}$ & Incomplete-markets parameter & 0.0001 \\
$\lambda$ & Fraction of rule-of-thumb consumers & 0.5 \\
\hline
\end{tabular}

In our calibration in Table D19, different utility functions imply the values of $\widetilde{\sigma}, \omega, \widetilde{v}, \psi$ in Table D20. When we calibrate the model with a generic utility function with complementarity, the values of these parameters are restricted to satisfy the necessary and sufficient conditions of concavity of the utility function, as well as non-inferiority of consumption and leisure stated in Bilbiie (2011). We target $\psi=2$ and change $\widetilde{\sigma}$ and $\omega$ accordingly.

Table D20. Utility Function: Calibrated Parameters

\begin{tabular}{lcc}
\hline Parameter & Separable Utility Function & Generic Utility Function \\
\hline$\widetilde{\sigma}$ & 2 & 3 \\
$\omega$ & 2 & 0.2 \\
$\widetilde{v}$ & 1.6 & 1.6 \\
$\psi$ & 0 & 2 \\
\hline
\end{tabular}

\section{D.6 Theoretical Predictions}

The figures in this section plot the responses of the real exchange rate, consumption, and the net exports-tooutput ratio under several scenarios. The size of the shock is 1 percent of GDP. 
Figure D3. Theoretical Predictions: Baseline Calibration
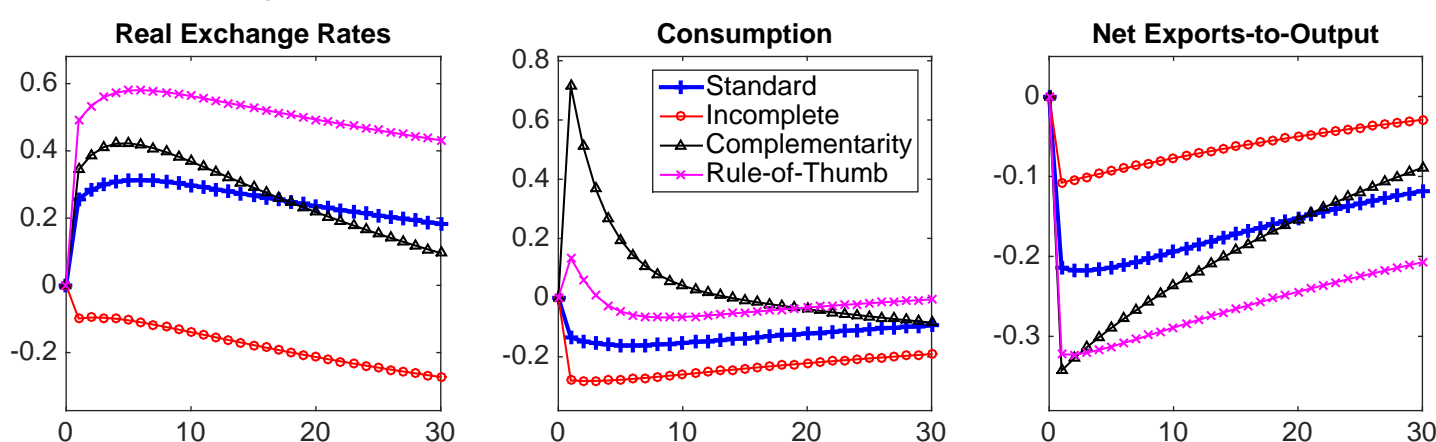

Notes: This figure plots the responses to a government spending shock of the real exchange rate, consumption, net exports-to-output ratio. An increase in the real exchange rate is appreciation. The models are the standard complete markets model (Standard), the model with incomplete markets (Incomplete), the incomplete markets model with consumption-hours complementarity (Complementarity), the complete markets model with ruleof-thumb consumers (Rule-of-Thumb). Note that the elasticity of substitution across home and foreign goods is $\gamma=0.75$ in the incomplete markets model.

Figure D4. Theoretical Predictions: Temporary Shock
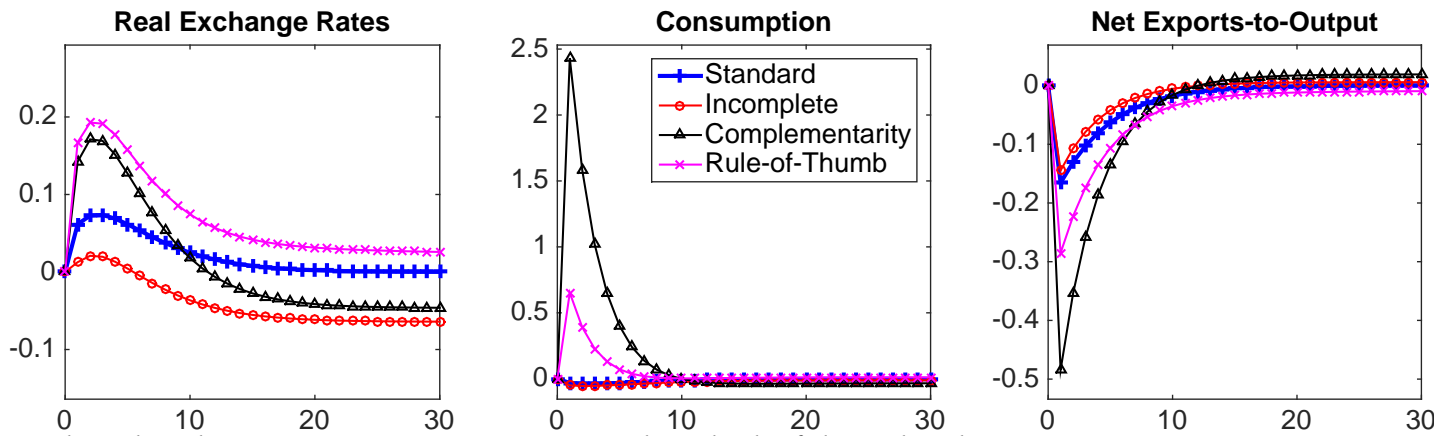

Notes: This figure plots plots the responses to a government spending shock of the real exchange rate, consumption, net exports-to-output ratio, as Figure D3 but the shock is temporary $\left(\rho_{G}=0.75\right)$. An increase in the real exchange rate is appreciation. The models are the standard complete markets model (Standard), the model with incomplete markets (Incomplete), the incomplete markets model with consumption-hours complementarity (Complementarity), the complete markets model with rule-of-thumb consumers (Rule-of-Thumb). Note that the elasticity of substitution across home and foreign goods is $\gamma=0.75$ in the incomplete markets model.

\section{Figure D5. Theoretical Predictions: Fixed Exchange Rate}
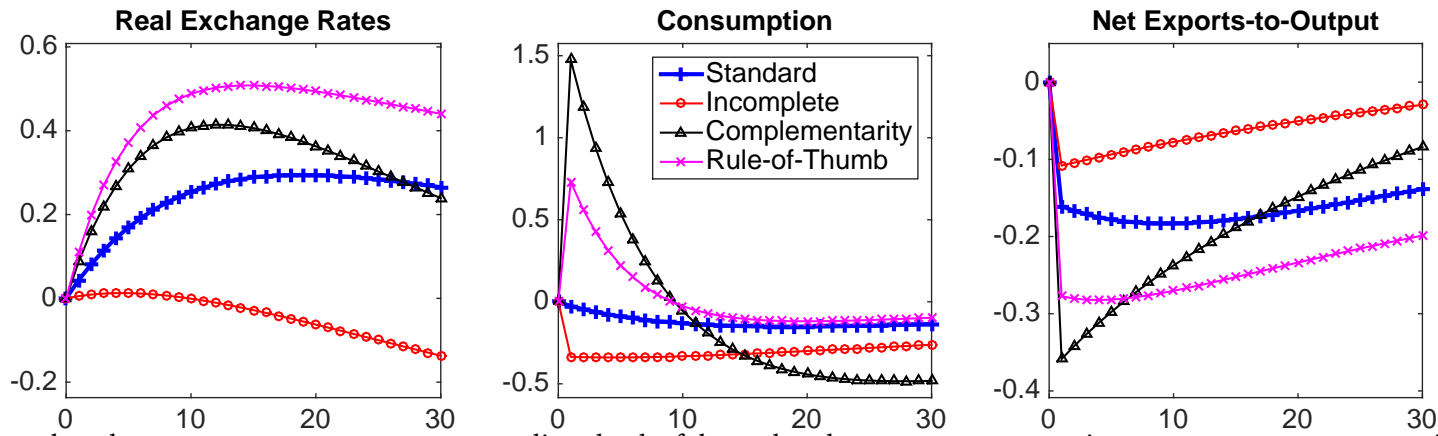

Notes: This figure plots the responses to a government spending shock of the real exchange rate, consumption, net exports-to-output ratio, as Figure D3 but under fixed exchange rate regime. We assume that the home country follows a fixed exchange rate regime, and the foreign country follows a Taylor rule. An increase in the real exchange rate is appreciation. The models are the standard complete markets model (Standard), the model with incomplete markets (Incomplete), the incomplete markets model with consumption-hours complementarity (Complementarity), the complete markets model with rule-of-thumb consumers (Rule-of-Thumb). Note that the elasticity of substitution across home and foreign goods is $\gamma=0.75$ in the incomplete markets model. 
Figure D6. Theoretical Predictions: Annual Frequency
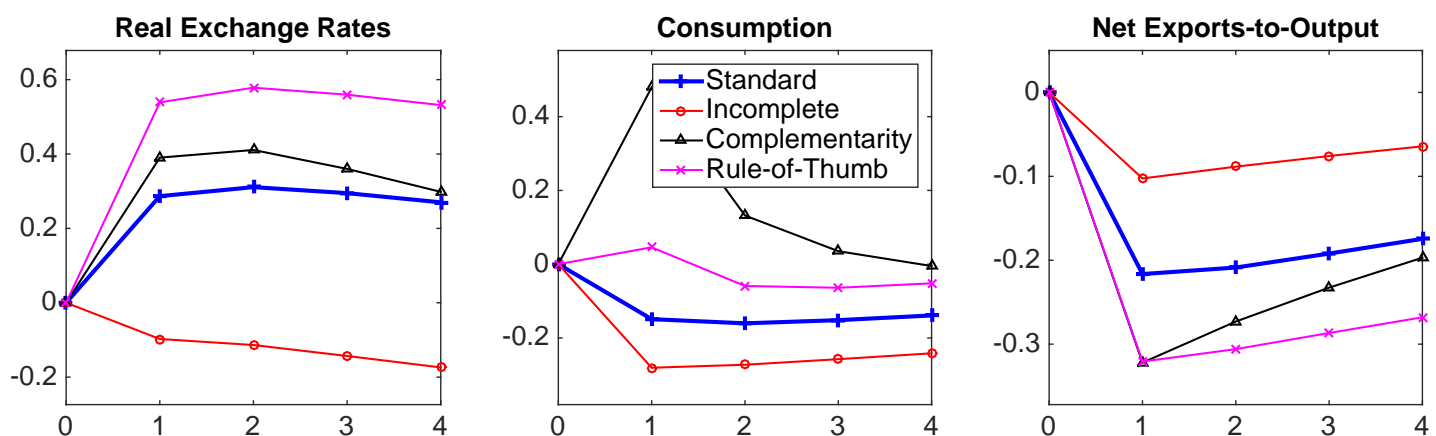

Notes: This figure plots the responses to a government spending shock of the real exchange rate, consumption, net exports-to-output ratio, as Figure D3 but converted to an annual frequency. An increase in the real exchange rate is appreciation. The models are the standard complete markets model (Standard), the model with incomplete markets (Incomplete), the incomplete markets model with consumption-hours complementarity (Complementarity), the complete markets model with rule-of-thumb consumers (Rule-of-Thumb). Note that the elasticity of substitution across home and foreign goods is $\gamma=0.75$ in the incomplete markets model. 